九州大学学術情報リポジトリ

Kyushu University Institutional Repository

\title{
Stratigraphical Studies of the Chichibu Belt in Western Shikoku
}

Kashima, Naruhiko

Department of Geology, Faculty of Science, Ehimé University

https://doi.org/10.5109/1543683

出版情報：九州大學理學部紀要：Series D, Geology. 19 (3)，pp.387-436，1969-11-10. Faculty of Science, Kyushu University バージョン :

権利関係 : 
Mem. Fac. Sci., Kyushu Univ., Ser. D, Geology, Vol. XIX. No. 3, pp. 387-436, text-figs. 1-9, pl. 54-60, Nov. 10, 1969

\title{
Stratigraphical Studies of the Chichibu Belt in Western Shikoku
}

\author{
By \\ Naruhiko KASHIMA
}

\begin{abstract}
In this paper the stratigraphy of the Upper Palaeozoic strata of the Chichibu belt in western Shikoku is described and also their stratigraphical, structural and metamorphic relationships with the northerly adjacent Mikabu green rocks and Sambagawa metamorphic rocks are analysed and discussed. In connection with the correlation palaeontologic descriptions are given for certain selected fusuline and coral species.

The Palaeozoic strata of western Shikoku, about $5300 \mathrm{~m}$ in total thickness, are of eugeosynclinal lithologic assemblage, consisting primarily of sandstone, slate or phyllite, chert and altered basic volcanic rocks (greenstones) with a small amount of limestone. Their stratigraphic sequence and correlation with the already established sequences outside the present area are summarized in Fig. 5.

The Carboniferous is represented by the Beedeina schellwieni zone and the Beedeina higoensis zone of the Oyabu Formation and also the Triticites yayamadakensis zone of the middle part of the Kaifuki Formation in the Nomura area. They are predominantly slate and sandstone with some intercalations of chert and green rock. The Kume Formation, which is distributed in the north and northeastern areas, consists mostly of black slate and phyllite and can be correlated with the above mentioned formations, on the basis of its stratigraphical position below the Lower Permian formation. The Lower Permian itself is represented by the Saitaro Formation in the northeastern Odamiyama and the northern Sugeta areas. It is dominantly thick green rocks with some beds of chert, and are characteristically accompanied with some dolomite lenses at the basal part. On the southern Oozu area, however, the Lower Permian strata consist of black slate and intercalated chert and sandstone. The lower part of the Uwagawa Formation is referred to the Pseudoschwagerina morikawai zone and the lower part of the Tanosuji Formation to the Pseudoschwagerina minatoi zone.

The Middle Permian is represented by the middle and upper parts of the Uwagawa Formation and the main part of the Nomura Formation of the Nomura area. They are composed of slate with occasional interbeds of chert and sandstone. Locally green rock is also contained. Owing to the paucity of fossil evidence, the main part of the above mentioned formations cannot be exactly dated, but the middle part of the Uwagawa Formation is referred to the Neoschwagerina simplex zone and the uppermost part of the Nomura Formation to the Yabeina globosa zone.
\end{abstract}

Manuscript received July 15, 1969.

Naruhiko Kashima: Visiting Research Associate, Faculty of Science, Kyushu University, 1968; Present address: Department of Geology, Faculty of Science, Ehimé University, Bunkyo-cho, Matsuyama, 790. 
The uppermost part of the Palaeozoic strata of this area is the Masagoya Formation which unconformably overlies the Lower Permian Nakakubo Formation. It is referable to the Yabeina globosa zone in the basal part and may range upward to Upper Permian. The formation consists of slate with some intercalates of sandstone and green rock.

Sandstones are dominantly of medium-grained feldspathic wacke, having more than 15 percent matrix, but partly feldspathic arenite.

Greenstones are of ophiolitic assemblage, consisting of altered basalt, dolerite, spilite, diorite, microgabbro and basaltic tuff and tuff breccia. They are products of submarine volcanism. The thickest pile of the greenstones, about $700 \mathrm{~m}$, is accumulated in the northern part of the area in the early Permian Saitaro Formation.

The Mikabu green rocks which are distributed along the boundary area between the Chichibu belt on the south and the Sambagawa metamorphic belt on the north are continuously extended to the green rock member of the Saitaro Formaion. Thus the Mikabu green rocks in western Shikoku are nothing but a member of this formation and early Permian in age.

There is an anticline along the boundary of the Sambagawa and Chichibu belts. Thus, the green schists of the southern marginal belt of the Sambagawa and the green rocks of the Saitaro Formation of the Chichibu occupy the northern and southern wings of the anticline, whereas the Kume Formation occupies the axial part. The bed of green schist of the northern wing is extended to the Minawa Formation which is widely distributed in the main part of the Sambagawa belt.

The Chichibu belt in the present area is divided into two metamorphic zones, mainly on the basis of the distribution and assemblage of the metamorphic minerals in the green rocks. They are a low grade prehnite-pumpellyite zone (Zone I) and a higher grade glaucophane schist zone (Zone II). Their mineral assemblages are shown in Table 4. The boundary between the two zones, which is represented by the amphibole isograd, runs in ENE-WSW direction, cutting obliquely the stratigraphical boundaries and a major structural form.

\section{Contents}

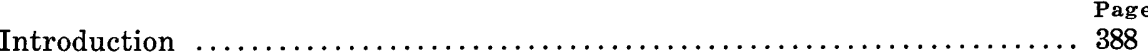

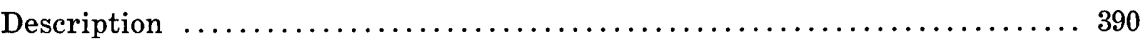

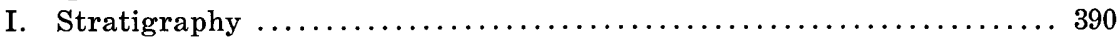

II. Palaeontological Description of Selected Species ................ 407

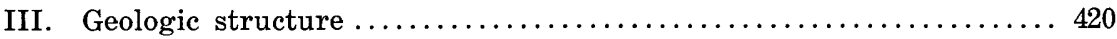

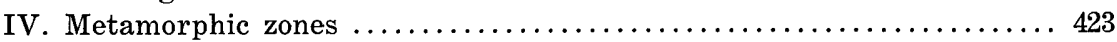

Discussion ........................................... 424

I. Relation between the Sambagawa southern marginal belt and the Chichibu belt ....................................... 424

II. Relation between the stratigraphical divisions and metamorphic

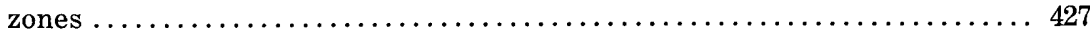

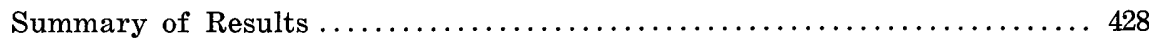

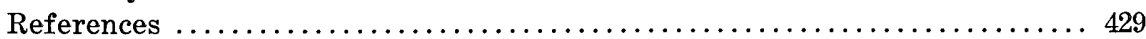

\section{Introduction}

The Chichibu belt of western Shikoku is occupied by Palaeozoic strata with a few, narrow Mesozoic tectonic inliers faulted within the Palaeozoic.

To the north of the Chichibu belt the metamorphic rocks of the Sambagawa 


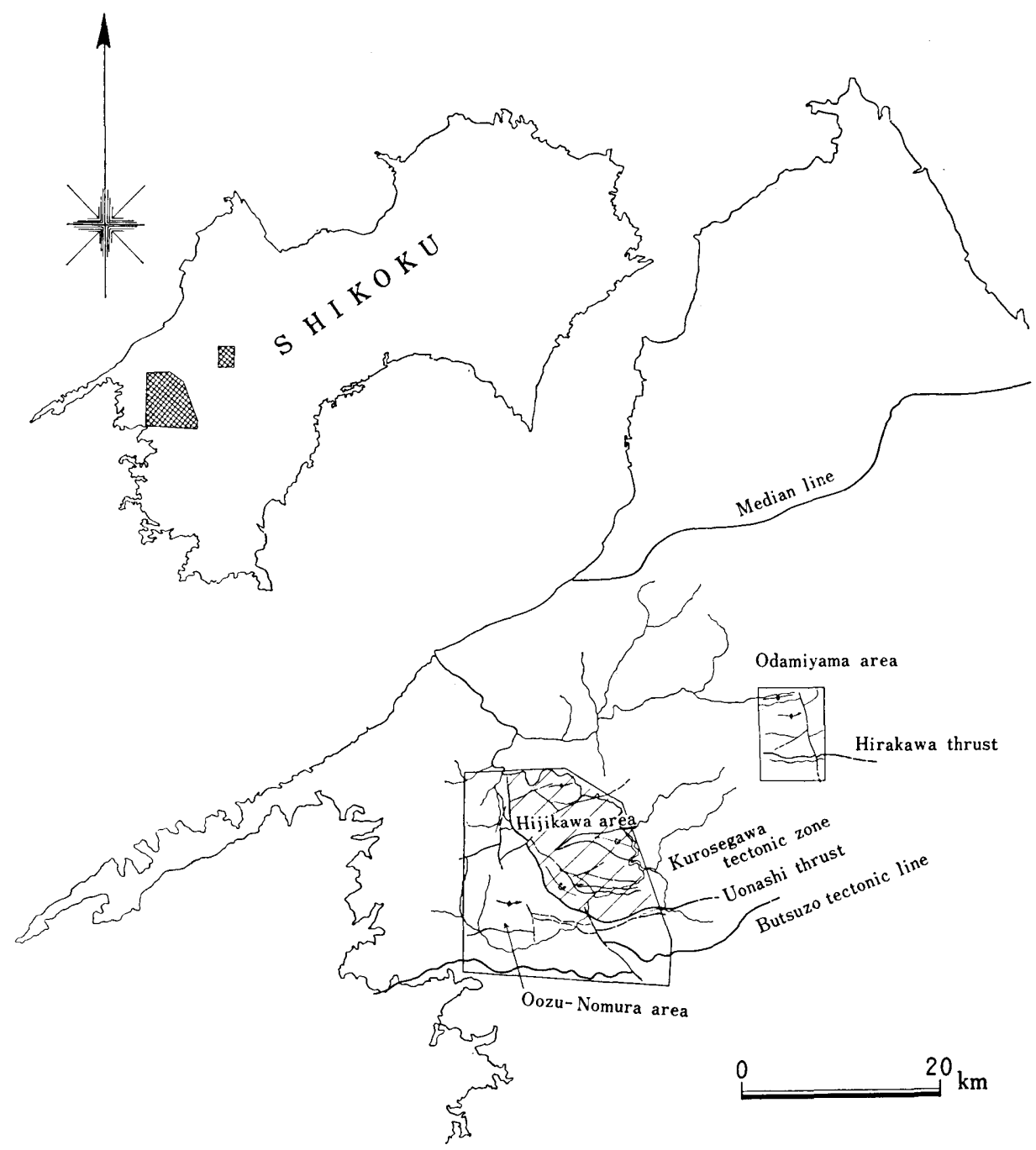

Fig. 1. Index map of the studied areas.

belt are widely distributed, and along the boundary zone between the two belts the Mikabu green rocks are prominently developed. In the south, the Chichibu belt is bounded by the Butsuzo tectonic line against the Shimanto belt of Cretaceous to Lower Tertiary.

Besides the pioneer work by Tatsuo SUzUKI (1935) on the general geology of western Shikoku, no comprehensive stratigraphic study on the Palaeozoic strata of the area has hitherto been made, although narrow areas near UonashiKurosegawa area, Yawatahama-Iyotakayama and Oda-kuma were locally mapped and studied in fair detail (YeHARA, 1928; IKEBE, 1936; NAKAGAWA et al., 1959; KaWASAWA, 1965; Hirayama and KAMBE, 1956; Takashi Suzuki, 1967).

The purpose of the present study is to investigate the stratigraphy of the Palaeozoic strata of the Chichibu belt in western Shikoku and furthermore to make clear the stratigraphical, structural and metamorphic relationships of the 
Palaeozoic strata of the Chichibu belt with the Mikabu green rocks and also with the metamorphic rocks of the Sambagawa belt. The present paper gives the result of the study.

For the above purpose two areas have been intensively studied. They are conventionally called the Odamiyama area in the east (Fig. 2) and the Hijikawa and the Oozu-Nomura area in the west (Fig. 3).

Acknowledgements.-The present work was completed in the Department of Geology, Kyushu University, during my visit in 1968-69. I wish to express my deepest appreciation to Professor Tatsuro Matsumoto who kindly supervised my work at Kyushu University, gave invaluable advice and constant encouragement and critically read manuscript. Special acknowledgement is due to Associate Professor Kametoshi KANMERA who gave me instructive advice in the field and laboratory work and read the first draft of this paper.

I am much indebted to Dr. Mitsuo Hashimoto of the National Science Museum and Professor Yotaro SEKI of the Saitama University who has petrologically examined the basic volcanic rocks of the studied area, and to Mr. Kiyoshi IsHIBASHI of the Kyushu University who has undertaken chemical analysis of basic volcanic rocks in my collection.

Sincere thanks are extended to Dr. Hakuyu OKADA of the Kyushu University, for his kind help in the study of sandstone, and to Dr. Itaru HaYAmI of the same university for his kind assistance in some laboratory work.

Acknowledgements are also due to Professor Kozo NagaI of the Ehime University for his interests in the general geology of the present area, to Professor Michitoshi MiYahisa of the same university, for his valuable advice and fruitful discussions in the field and laboratory work, and to Professor Kazue HORIKOSHI of the same university, for his constant encouragement.

I appreciate also the kindness of the following who have helped in various ways: Mr. Kiyoshi Higaki, Mr. Takuro Hiraoka, Mr. Morioki TokiwaI and Mr. Mitsuyasu SHIBA.

I wish to express my thanks for the supply of Grant in Aid for Fundamental Scientific Research of the Ministry of Education.

\section{Description}

\section{Stratigraphy}

The stratigraphy of the Palaeozoic and Mesozoic formations of the present area is described in this chapter. The geological outline map is shown in Fig. 1 and the stratigraphic sequence in Fig. 5, with a result of correlation. The scheme of subdivision of Upper Carboniferous and Permian sequences in this paper is based on the standards established by KANMERA (1955 and 1963) and that of sandstone classification depends on that defined by OKADA (1968).

\section{A. Carboniferous System}

1. Oyabu Formation

The Oyabu Formation is typically exposed along the Oyabu and the Ootani 


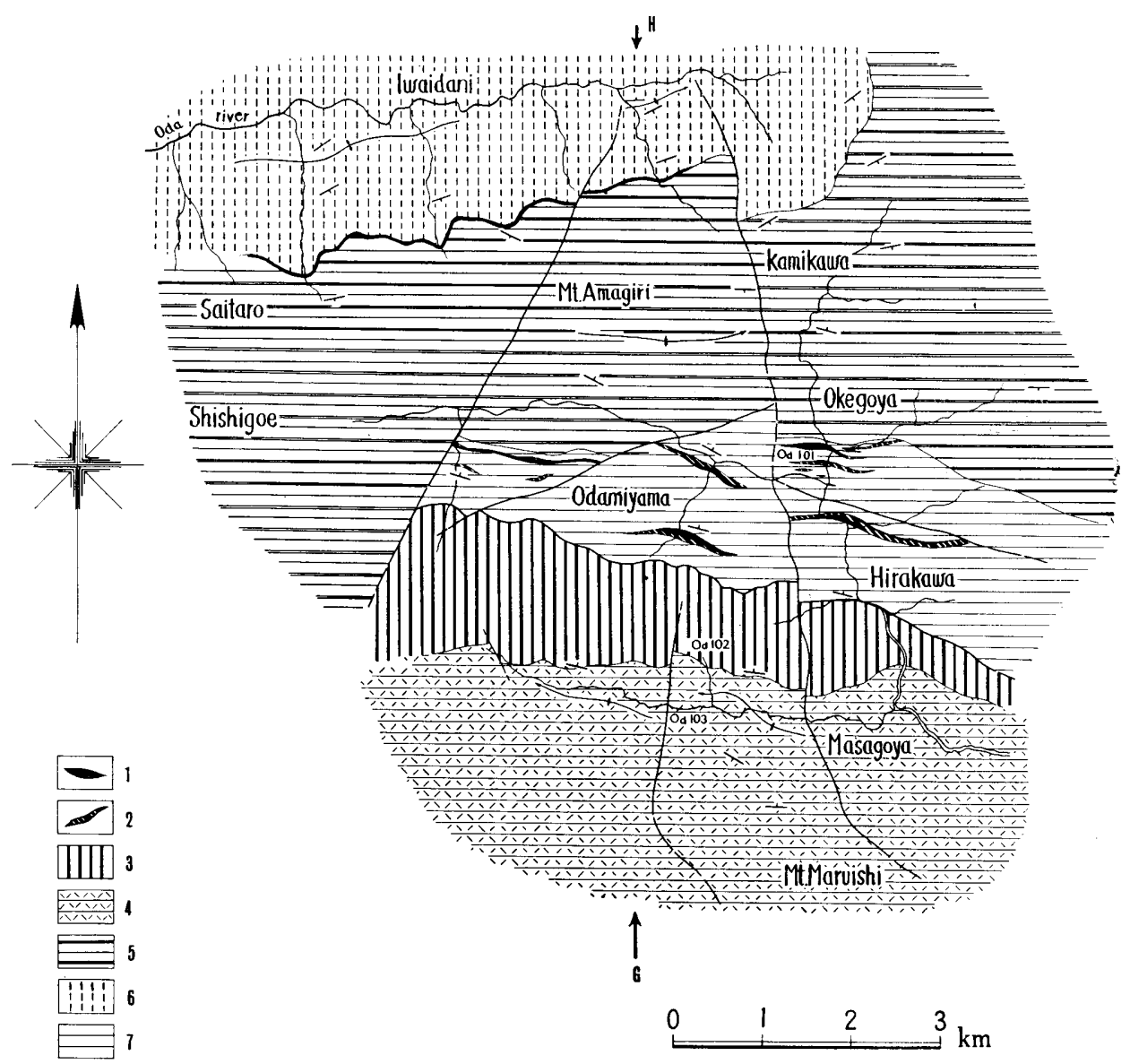

Fig. 2. Geological map of the Odamiyama area.

1: limestone, 2: dolomite, 3: Masagoya Formation, 4: Nakakubo Formation, 5: Saitaro Formation, 6: Kume Formation, 7: Odamiyama Formation.

river and their tributaries in Hijikawa Town. From Shiraishi westward to Funabara there occurs a narrow belt of this formation which is bounded by faults on the northern and southern sides.

The formation is somewhat thicker than $1080 \mathrm{~m}$.

It is lithostratigraphically subdivided into the upper, middle and lower part. The lower part consists mainly of slate and sandstone, with intercalation of dacitic lavas and lenticular limestone. The major constituents of the sandstone are mainly composed of subangular, coarse grains of feldspar, quartz and rock fragments. The dominant rock fragments are volcanic rocks (98.1 percent), with a small amount of debris of chert and other sedimentary rocks. Selected two samples $(66031314,6604109)$ have a composition as shown in Tables 1,3 and Figs. 6, 7. They are characterized by the predominance of feldspars. The feldspars include plagioclase and orthoclase, the former of which belongs mainly to labradorite. One of the samples (66040109) belongs to feldspathic arenite and 
the other to feldspathic wacke which are poorly sorted. The limestone is made up of well sorted, algae circumcrusted crinoid-fusuline biosparrudite. Main bioclasts are those of crinoid ossicles, fusulines, smaller foraminifers, dasycladacean algae and a few bryozoa. The following fusuline species have been identified from the limestone.

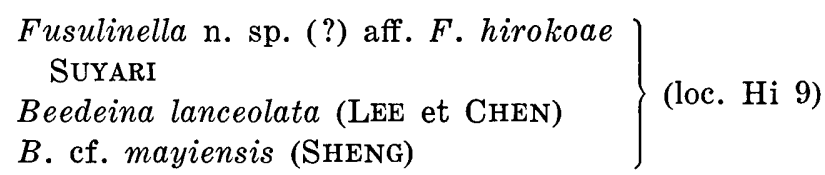

The middle part consists of basalt lavas with some lenses of limestone. Some parts of basalt show an amygdaloidal structure. The limestones are made up of calclithite (loc. Hi 8), crystalline calcite grains (loc. Hi 10) and poorly sorted crinoid intraclastic biosparrudite (loc. Hi 11). They contain the following fossils.

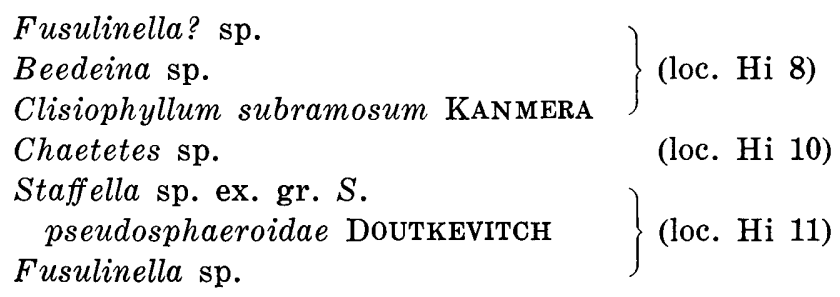

The upper part consists mainly of slate and sandstone with intercalation of chert. There are two types of sandstone, lithic wacke (with 21.0 percent muddy matrix) and feldspathic one (with 26.4 percent muddy matrix). The major constituents of the former are mainly volcanic rock fragments, feldspar and quartz, of which volcanic fragments range from 56 to 41 percent in content and consist of glassy andesite (?), dolerite and basaltic rocks. The feldspathic wacke has a composition of quartz 36.3, feldspar 48.6 and rock fragments 15.1 as an average percentage of four samples. The feldspars include plagioclase, orthoclase, microcline and perthite. The composition of plagioclase ranges from bytownite to labradorite. Rock fragments consist mainly of volcanic rocks and subordinately of granitic and sedimentary rocks. Metamorphic rock debris are rarely found. All the sandstones are made up of poorly sorted, subangular coarse grains.

The fusulines and corals listed above seem to indicate that the lower part of this formation is referred to the Akiyoshian, i.e. the zone of Fusulinella biconica of the Upper Carboniferous, and the Kurikian, i.e. the zone of Staffella pseudosphaeroidae of the same System.

\section{Kaifuki Formation}

The name of the Kaifuki Formation was first applied by IKEBE (1936) to the Palaeozoic strata which are widely distributed on the northern side of the Kamanokawa thrust, which is known at present as the Kurosegawa tectonic zone. In this paper, however, this formation is restricted to the southern onethird of the originally designated distribution.

The northern boundary of the formation is a fault relation to the Uwagawa 
Formation. At the southern margin, the formation is in contact with the Mitaki granite of the Kurosegawa tectonic zone. The argillaceous rocks of the formation adjoing or close to this tectonic zone are converted to phyllite or phyllitic slate.

The formation, about $900 \mathrm{~m}$ thick, consists mainly of slate with some intercalations of basic tuff and chert in the lower part and those of sandstone in the upper. The microgabbro occurring in the lower part may be a part of a basaltic lava or a sill or dike associated with the basaltic rock. A few lenticular bodies of limestone of less than $10 \mathrm{~m}$ thick occur in the lower part.

The framework constituents of the sandstone in the upper part are as follows: quartz 33.8, feldspar 41.5 and rock fragments 24.7 percent. The rock type of the sandstone is feldspathic wacke, which contains the matrix of 25.8 percent. The feldspar grains include plagioclase, orthoclase, microcline and perthite. The plagioclase falls in andesine-labradorite in composition. The rock fragments consist of volcanic rocks (90.5 percent of the fragments), chert (7.9 percent) and other sedimentary rocks. These sand grains are subrounded and poorly sorted.

The limestone is more or less recrystallized but is primarily made up of algal pisolitic biomicrite (loc. Hi 17). It contains Triticites sp. ex. gr. T. yayamadakensis KANMERA. Therefore, at least the lower part is referred to the Hikawan, i.e. the zone of Triticites yayamadakensis of the upper Upper Carboniferous.

\section{Odamiyama Formation}

The Odamiyama Formation was named by MiYahisa et al. (1964) for the strata which are distributed in the Odamiyama area, Oda Town. It is about $450 \mathrm{~m}$ in thickness and conformably overlain by the Saitaro Formation and is delimited by the Hirakawa thrust against the Masagoya Formation.

The lower part (about $300 \mathrm{~m}$ in thickness) of the formation consists predominantly of alternating sandstone and slate with some beds of chert. The upper part consists of thick beds of chert with laminated red tuff, microgabbro, basaltic tuff, slate, limestone and dolomite. The upper part of the formation characteristically consists of red chert, with red siliceous tuff partings, and limestone and/or dolomite, with some thin intercalations of basaltic tuff. The detailed succession of this lithologic assemblage is shown in Fig. 4.

A limestone at Okegoya which consists of extraclastic detrital limestone (calclithite) of granule to coarse-grained sand-size contains the following fusuline fossils.

Millerella sp.

Eostaffella kanmerai (IGO)

Pseudostaffella cf. kanumai (IGo)

Fusiella cf. hayashii (IGo)

Fusulinella itoi OzAwA

$F$. $\quad$ cf. hanzawai (IGo)

$F$. $\quad$ cf. pseudobocki LEE et CHEN

$F$. $\quad$ sp. B

Fusulina sp. 


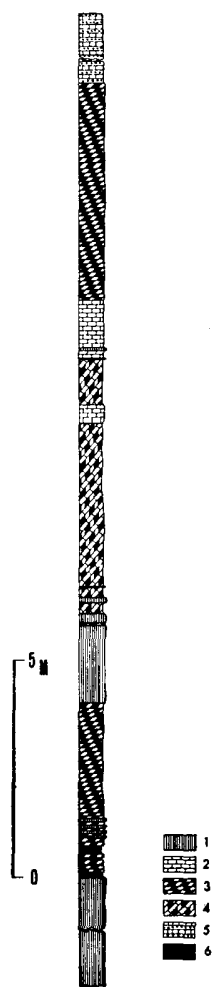

Fig. 4. Lithologic assemblage in the upper part of the Odamiyama Formation.

1: chert with siliceous tuff partings, 2: limestone, 3: dolomite, 4: limestone and dolomite in alternation, 5: detrital limestone, 6: red tuff.

This fusuline assemblage is apparently of the Middle Carboniferous Fusulinella-Fusulina Zone. But the contained species are all of detrital origin and do not show the age of the deposition of the limestone itself. It is, however, clear that the limestone is not older than the Fusulinella-Fusulina Zone.

The limestone bed may be referable to the Upper Carboniferous.

\section{Kume Formation}

The gray and green phyllitic rocks of the Kume area were named the Kume Series by SuzukI (1935). This can be, however, lithostratigraphically subdivided into two formations, namely, the Kume Formation (s.s.) below and the Futaiwa Formation above (to be described under Permian).

The Kume Formation in a revised sense is distributed in the western Oozu area and the eastern Odamiyama area. Its type exposures are found at Matsuo, Inazumi, Kuroki and Noda of the Oozu area. It consists mainly of black phyllite with a very small amount of sandstone, chert and basic tuff. The sandstone is weakly metamorphosed, and shows a phyllitic texture. Its major composition is as follows (the average percentage of three specimens): quartz 67.0, feldspar 28.6 and rock fragments 4.4. The feldspars include plagioclase and orthoclase. The plagioclase is mainly andesine in composition. The rock fragments are of volcanic rocks. The examined sandstones belong to feldspathic wacke.

A bed of green phyllite converted from basaltic tuff is contained in the upper part of the formation. 
The lower limit of the formation cannot be determined, but, so far as is exposed, the formation exceeds $1000 \mathrm{~m}$ in thickness.

In the eastern Odamiyama area, the Kume Formation is distributed along the upper reaches of the Oda-river and its tributaries with a general strike of ENE-WSW. The lowermost member is exposed along the axis of a longitudinal anticline in the central part of the belt of this formation. On the southern wing of the anticline the formation is conformably overlain by the Saitaro Formation.

The formation consists mainly of black phyllite with a few thin beds of chert. On the south side of Iwaidani a thin bed of green phyllite (Pl. 57, Fig. 1), which was converted from basaltic tuff, is intercalated in the lower part. So far as is exposed, the thickness of the formation is $840 \mathrm{~m}$ to $940 \mathrm{~m}$, on the southern wing.

No fossils have been found from the formation either in the west or in the east. Although the exposures are not continuous, the above described strata in the western Oozu area and those in the eastern Odamiyama area are probably of the same formation, because they underlie the Lower Permian strata and because they have similar lithologic characters. The Kume formation and the Odamiyama Formation in the eastern Odamiyama area must be of the same age, because the two formations, as seen in the geological map (Fig. 2), conformably underlie the Lower Permian Saitaro Formation on the northern and the southern wing, respectively, although they differ in lithofacies.

\section{B. Permian System}

\section{Saitaro Formation}

The Saitaro Formation is distributed in the eastern Odamiyama area and the western Hijikawa area.

In the eastern Odamiyama area, the Saitaro Formation is exposed in the vicinity of the Shishigoe-pass, Mt. Amagiri and the Kamikawa-pass of Oda Town. The strata form an open symmetrical syncline with an axis plunging to the east in the Mt. Amagiri area. It conformably rests on the Kume Formation on the northern wing and the Odamiyama Formation on the southern wing.

The formation, about $1400 \mathrm{~m}$ in total thickness, is made up of lower green phyllite with some intercalations of chert $(740 \mathrm{~m})$, the middle black phyllite $(300 \mathrm{~m})$ and the upper green phyllite, chert and red phyllite $(360 \mathrm{~m})$. The lower limit of the formation is taken at the base of a thin limestone bed which is fairly consistently traceable in the surveyed area. Small lenticular bodies of limestone are also found in the uppar part. The limestone of these two levels are made up of fine recrystallized pseudosparite with many stylolites within them. The green phyllite contains less metamorphosed parts of dolerite and basaltic tuff. No fossils have been found in this area.

In the western Hijikawa area, the formation is typically exposed along the left bank of the Hiji-river, from Ogura to Moriyama, and the Yatsuko river and its tributaries. It is faulted against the Uwagawa Formation on the southern side but its northern limit has not yet been determined. 
The formation is about $1480 \mathrm{~m}$ in total thickness. The lower part, about $480 \mathrm{~m}$ is made up predominantly of volcanic rocks, such as basalt, microgabbro, diorite, pyroxenite and basaltic tuff, with thin beds of chert. The basalt shows porphyritic texture (see Pl. 58, Fig. 3). These volcanic rocks represent an ophiolitic assemblage. The middle part $(760 \mathrm{~m})$ consists mainly of slate with some interbeds of chert and sandstone and accompanies small, thin lenses of limestone in the middle part. The framework constituents of the selected sandstone sample consist of quartz, feldspar, and rock fragments. The feldspars include plagioclase, orthoclase, microcline and perthite. Plagioclase grains are angular to subangular and belong mainly to the labradorite. The sandstone type is as a whole feldspathic wacke (with the matrix of 23.7 percent). The framework composition of a specimen is quartz 48.7, feldspar 38.4 and rock fragments 12.9 percent.

The limestone is highly recrystallized and foliated, but it is primarily made up of pseudomicrite. Squashed specimens of Schwagerina? sp. or Pseudofusulina? sp. (loc. Hi 1) have been obtained from it. The upper part $(240 \mathrm{~m})$ consists of black phyllite and green phyllite.

The fusuline fossils mentioned above are strongly deformed but they are of the Lower Permian type in shell structure.

The ophiolites of the lower part are extended eastward to the Ookuki area where they have been assigned to the Mikabu green rocks.

\section{Futaiwa Formation}

The formation was named by Hirayama and Kambe (1956). It is distributed in the vicinities of Umenokawa, Yokono, Kitaura, Okushirahige and Tosaka.

It conformably rests on the Kume Formation and underlies the Tanosuji Formation, as seen in the Yawatahama and Ino areas, although it is in fault contact with the Tanosuji Formation in the main part of the surveyed area.

The formation, about $900 \mathrm{~m}$ thick, consists of black phyllite, basalt lava, basic tuff, chert, sandstone and limestone. A lowest boundary of the formation is taken at the level of limestone lenses which are discontinuously traceable in the surveyed area. These limestones contain dolomitic part in places. The sandstone is mainly composed of subangular grains of feldspar and quartz. The former includes plagioclase, orthoclase, microcline and perthite, of which the plagioclase has a composition of andesine(?)-labradorite. The rock fragments consist of volcanics (77.6 percent of the rock fragments), granite (12.0 percent) and the debris of chert and other sedimentary rocks (not abundant). The average detrital composition of five specimens is as follows: quartz 46.5, feldspar 45.2 and rock fragments 8.3. The sandstones belong to feldspathic arenite (with the matrix of 11.8 percent) and feldspathic wacke (with the matrix of 22.4 percent).

The limestone in the northern area is recrystallized to pseudosparite and pseudodismicrite. Therefore, no fossils have been collected.

The formation is probably referred to the Lower Permian and underlies the upper Lower Permian to lower Middle Permian Tanosuji Formation. 
Table 1. Modal analysis of sandstones (in percentage)

\begin{tabular}{|c|c|c|c|c|c|}
\hline Formation & Sp. no. & Quartz & Feldspar & $\begin{array}{c}\text { Rock } \\
\text { fragments }\end{array}$ & Matrix \\
\hline Itagatani & $\begin{array}{r}64081602 \\
65031502 \\
21 \\
61 \\
17 \\
10 \\
64081903 \\
64081301 \\
64081403 \\
65031719 \\
65032708 \\
30 \\
65031504 \\
65031703 \\
64081412 \\
1 \\
65032703 \\
64081607 \\
64081605 \\
64081704 \\
65041414 \\
65041621 \\
65041404 \\
65041403 \\
64081604 \\
65041606 \\
64081303 \\
65041605 \\
65041704 \\
49\end{array}$ & $\begin{array}{l}40.9 \\
48.1 \\
42.6 \\
57.4 \\
36.7 \\
44.9 \\
41.0 \\
32.7 \\
39.4 \\
46.1 \\
48.4 \\
52.7 \\
44.3 \\
45.4 \\
50.8 \\
44.9 \\
56.0 \\
54.7 \\
39.4 \\
44.7 \\
55.3 \\
50.8 \\
42.0 \\
39.0 \\
37.0 \\
50.8 \\
39.4 \\
45.3 \\
43.5 \\
33.5\end{array}$ & $\begin{array}{l}49.6 \\
45.2 \\
47.0 \\
28.9 \\
48.8 \\
45.7 \\
26.9 \\
56.8 \\
52.2 \\
49.9 \\
49.4 \\
37.8 \\
45.8 \\
47.0 \\
44.5 \\
43.1 \\
41.0 \\
20.1 \\
47.9 \\
38.0 \\
38.9 \\
43.9 \\
45.4 \\
53.0 \\
55.9 \\
35.8 \\
54.7 \\
48.4 \\
50.6 \\
55.3\end{array}$ & $\begin{array}{r}9.5 \\
6.7 \\
10.4 \\
13.7 \\
14.5 \\
9.4 \\
32.1 \\
10.5 \\
8.4 \\
3.8 \\
2.2 \\
9.5 \\
9.9 \\
7.6 \\
4.7 \\
12.0 \\
3.0 \\
25.2 \\
12.6 \\
17.3 \\
5.8 \\
5.3 \\
12.7 \\
8.0 \\
7.0 \\
13.3 \\
5.9 \\
6.3 \\
5.9 \\
11.2\end{array}$ & $\begin{array}{r}33.6 \\
16.5 \\
27.7 \\
28.1 \\
16.4 \\
28.1 \\
26.1 \\
33.4 \\
23.7 \\
16.3 \\
18.9 \\
15.1 \\
19.6 \\
16.6 \\
26.0 \\
15.0 \\
17.3 \\
14.4 \\
9.9 \\
12.1 \\
13.2 \\
14.2 \\
14.4 \\
10.5 \\
12.6 \\
13.6 \\
12.4 \\
13.4 \\
12.3 \\
14.5\end{array}$ \\
\hline Masagoya & $\begin{array}{l}65032913 \\
65032910 \\
65033012\end{array}$ & $\begin{array}{l}45.1 \\
37.3 \\
33.5\end{array}$ & $\begin{array}{l}50.5 \\
42.7 \\
48.0\end{array}$ & $\begin{array}{r}4.4 \\
20.0 \\
18.4\end{array}$ & $\begin{array}{l}26.9 \\
23.3 \\
25.2\end{array}$ \\
\hline Nomura & 65082903 & 50.0 & 44.8 & 5.2 & 29.5 \\
\hline Tanosuji & $\begin{array}{r}65053002 \\
4 \\
65081603 \\
65081602 \\
65031804 \\
65052905 \\
65041609 \\
65031303 \\
65031413 \\
65031901 \\
65061301 \\
65041809 \\
65041803 \\
65032616 \\
65041711 \\
65031909 \\
65031718 \\
65052806 \\
65082502 \\
65052704 \\
65031806 \\
65081605 \\
65052805 \\
65041808 \\
65032610 \\
65032613\end{array}$ & $\begin{array}{l}29.8 \\
41.5 \\
45.2 \\
38.3 \\
49.9 \\
42.3 \\
43.3 \\
49.5 \\
36.8 \\
46.7 \\
33.8 \\
47.4 \\
20.2 \\
54.0 \\
43.8 \\
51.0 \\
38.3 \\
37.5 \\
46.2 \\
46.6 \\
40.0 \\
34.2 \\
53.8 \\
40.7 \\
41.8 \\
46.0\end{array}$ & $\begin{array}{l}64.9 \\
56.0 \\
36.1 \\
53.3 \\
42.1 \\
49.5 \\
47.6 \\
40.5 \\
56.5 \\
34.6 \\
55.1 \\
48.2 \\
31.5 \\
44.5 \\
45.9 \\
41.6 \\
41.3 \\
54.0 \\
43.5 \\
51.0 \\
51.5 \\
43.7 \\
33.3 \\
56.5 \\
37.0 \\
43.0\end{array}$ & $\begin{array}{r}5.3 \\
2.5 \\
18.7 \\
8.3 \\
8.0 \\
8.2 \\
9.0 \\
10.0 \\
6.7 \\
18.7 \\
11.1 \\
4.4 \\
48.3 \\
1.5 \\
10.2 \\
7.4 \\
20.4 \\
8.5 \\
10.3 \\
2.4 \\
8.5 \\
22.0 \\
12.8 \\
2.8 \\
21.2 \\
11.0\end{array}$ & $\begin{array}{l}21.0 \\
16.3 \\
15.2 \\
19.3 \\
19.6 \\
29.5 \\
31.5 \\
27.7 \\
27.1 \\
26.5 \\
26.5 \\
16.3 \\
18.2 \\
16.5 \\
16.7 \\
18.5 \\
20.1 \\
17.3 \\
15.7 \\
15.8 \\
14.0 \\
13.5 \\
13.3 \\
12.8 \\
14.5 \\
13.0\end{array}$ \\
\hline
\end{tabular}




\begin{tabular}{|c|c|c|c|c|c|}
\hline Formation & Sp. no. & Quartz & Feldspar & $\begin{array}{c}\text { Rock } \\
\text { fragments }\end{array}$ & Matrix \\
\hline Tanosuji & $\begin{array}{l}65031809 \\
65031511 \\
65031707 \\
65031705 \\
65031306 \\
65061509 \\
65061302\end{array}$ & $\begin{array}{l}38.5 \\
32.9 \\
48.2 \\
53.5 \\
40.4 \\
45.9 \\
44.5\end{array}$ & $\begin{array}{l}59.7 \\
54.1 \\
49.9 \\
40.4 \\
44.2 \\
24.6 \\
53.3\end{array}$ & $\begin{array}{r}1.8 \\
12.9 \\
1.9 \\
6.1 \\
15.4 \\
29.5 \\
2.2\end{array}$ & $\begin{array}{l}13.2 \\
11.3 \\
14.4 \\
10.6 \\
14.1 \\
14.5 \\
14.3\end{array}$ \\
\hline Uwagawa & $\begin{array}{l}65082218 \\
65082216 \\
66031204 \\
66031622 \\
66031626 \\
66031708 \\
66031210 \\
66031628 \\
65081712 \\
65082912 \\
66041004 \\
66031425 \\
66040909 \\
66040818 \\
66040917 \\
66041201 \\
66040814 \\
66040101 \\
68090205 \\
66031705 \\
66031220 \\
66041602 \\
66040910 \\
66040821\end{array}$ & $\begin{array}{l}38.8 \\
32.6 \\
33.3 \\
34.8 \\
46.4 \\
42.9 \\
50.1 \\
40.2 \\
50.2 \\
36.8 \\
38.7 \\
16.6 \\
31.4 \\
31.1 \\
34.9 \\
24.7 \\
40.4 \\
42.0 \\
18.5 \\
39.9 \\
39.0 \\
33.3 \\
22.5 \\
29.6\end{array}$ & $\begin{array}{l}32.4 \\
47.3 \\
46.0 \\
64.8 \\
41.1 \\
55.1 \\
47.0 \\
36.2 \\
46.6 \\
58.9 \\
32.9 \\
26.6 \\
54.9 \\
55.9 \\
52.4 \\
53.8 \\
47.1 \\
48.3 \\
38.7 \\
54.3 \\
51.5 \\
53.9 \\
44.3 \\
44.6\end{array}$ & $\begin{array}{r}28.8 \\
20.1 \\
20.7 \\
0.9 \\
12.5 \\
2.1 \\
2.9 \\
23.6 \\
3.2 \\
4.2 \\
28.3 \\
56.8 \\
13.7 \\
13.0 \\
12.7 \\
21.6 \\
12.5 \\
9.7 \\
42.8 \\
5.8 \\
9.5 \\
12.8 \\
33.2 \\
26.0\end{array}$ & $\begin{array}{l}18.8 \\
28.3 \\
23.3 \\
34.3 \\
39.9 \\
29.1 \\
20.9 \\
19.5 \\
16.3 \\
19.4 \\
31.3 \\
33.0 \\
17.2 \\
18.3 \\
31.7 \\
21.4 \\
16.5 \\
13.8 \\
13.4 \\
14.7 \\
11.5 \\
12.8 \\
10.0 \\
14.5\end{array}$ \\
\hline Saitaro & 65081706 & 48.7 & 38.4 & 12.9 & 23.7 \\
\hline Futaiwa & $\begin{array}{l}65052904 \\
65082408 \\
65053004 \\
65081802 \\
65081713\end{array}$ & $\begin{array}{l}39.1 \\
53.0 \\
45.8 \\
42.8 \\
52.0\end{array}$ & $\begin{array}{l}47.6 \\
41.1 \\
47.9 \\
48.0 \\
41.4\end{array}$ & $\begin{array}{r}13.3 \\
5.9 \\
6.3 \\
9.2 \\
6.7\end{array}$ & $\begin{array}{r}27.0 \\
17.2 \\
14.0 \\
12.7 \\
8.6\end{array}$ \\
\hline Kume & $\begin{array}{l}65081807 \\
65082309 \\
65082307\end{array}$ & $\begin{array}{l}57.3 \\
82.8 \\
60.8\end{array}$ & $\begin{array}{l}40.4 \\
16.4 \\
29.5\end{array}$ & $\begin{array}{l}2.3 \\
1.2 \\
9.7\end{array}$ & $\begin{array}{l}* \\
* \\
*\end{array}$ \\
\hline Kaifuki & 65082817 & 33.8 & 41.5 & 24.7 & 25.8 \\
\hline Oyabu & $\begin{array}{l}66031404 \\
66040930 \\
66031413 \\
66031419 \\
66031407 \\
66041002 \\
66031411 \\
66040109 \\
66031314\end{array}$ & $\begin{array}{l}15.4 \\
40.9 \\
12.4 \\
30.7 \\
29.9 \\
38.6 \\
35.1 \\
34.7 \\
21.5\end{array}$ & $\begin{array}{l}35.8 \\
44.7 \\
20.0 \\
63.3 \\
26.0 \\
39.2 \\
47.1 \\
33.8 \\
58.3\end{array}$ & $\begin{array}{r}48.8 \\
14.4 \\
67.6 \\
6.0 \\
44.1 \\
22.2 \\
17.8 \\
31.5 \\
20.2\end{array}$ & $\begin{array}{l}25.7 \\
26.4 \\
15.2 \\
11.7 \\
14.6 \\
11.5 \\
14.6 \\
10.2 \\
25.0\end{array}$ \\
\hline Imaidani & $\begin{array}{l}64041707 \\
65032710\end{array}$ & $\begin{array}{l}49.2 \\
38.0\end{array}$ & $\begin{array}{l}47.5 \\
55.1\end{array}$ & $\begin{array}{l}3.4 \\
6.9\end{array}$ & $\begin{array}{l}17.9 \\
12.7\end{array}$ \\
\hline
\end{tabular}

* phyllitic sandstone. 


\section{Tanosuji Formation}

The Tanosuji Formation is distributed in the Tanosuji and Tanisuji areas. It forms a major semi-basin structure slightly plunging to the east and is faulted against the Futaiwa Formation on the north side, but conformably rests on the latter on the south side. To the west of Ino it is faulted against the Itagatani Formation of the Sambosan belt. In the east it is limited by the Uonashi thrust.

The formation is about $2000 \mathrm{~m}$ in total thickness and consists of alternating members of chert, slate and sandstone, with intercalation of a limestone bed. Chert is the most predominant of all, forming a member of $240 \mathrm{~m}$ in the lower part. But as the succession is followed upwards, sandstone gradually increases in amount. In the uppermost part a few lenticular beds of conglomerate are associated with the sandstone. The chert sometimes contains manganese ore deposits. It is not accompanied with volcanic and pyroclastic rocks.

The sandstone is as a whole coarse-grained and poorly sorted. The textural framework of sandstones is constructed by feldspar, quartz and rock fragments. The feldspars include plagioclase, orthoclase, microcline and perthite. The plagioclase grains have a composition of andesine to labradorite. The rock fragments consist mainly of volcanic rocks (78.2 percent of the whole fragments) and subordinately of the debris of chert (11.8 percent). The composition of detrital grains is as follows: quartz 42.5, feldspar 46.3 and rock fragments 11.2 (the average percentage of thirty three specimens). About one-third of the samples belongs to feldspathic arenite (with the matrix of 13.3 percent) and the two-thirds to feldspathic wacke (with 20.9 percent).

A limestone bed is found at Tojikano in the lower part, Nomura Town. It is made up originally of biomicrite, but more or less recrystallized to coarse calcite. It contains the following fossils.

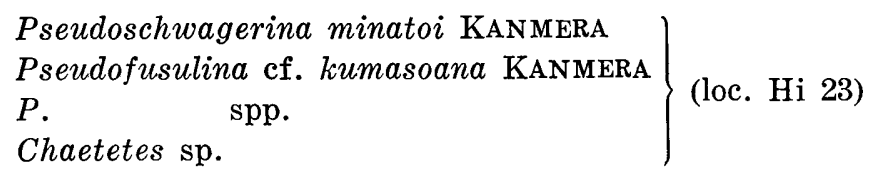

The fusuline species are evidently of the Lower Permian Pseudoschwagerina minatoi zone.

The conglomerate in the uppermost part is made up of pebbles and cobbles of limestone, chert, slate and dolomite. In the limestone pebbles the following species is identified.

Neoschwagerina cf. simplex OzaWA (loc. Hi 20).

This indicates that the uppermost part of the formation is not older than Neoschwagerina simplex zone.

\section{Uwagawa Formation}

The Uwagawa formation is widely distributed in the Uwagawa area and the Tochinoki valley with the general strike of WNW-ESE. It is also well exposed on the western slope of Mt. Gozaisho, and in the vicinities of Nakadori and Kuriki. 
The formation is in fault contact with the Kaifuki Formation on the southern side and is limited on the western margin by the Uonashi thrust.

The formation, at least $2300 \mathrm{~m}$ or more in total thickness, is composed of black phyllite, slate and sandstone, with intercalation of limestone, basalt, basaltic tuff and chert. The limestone is found at some levels of the lower part and most of the pyroclastic rocks and lava are contained in the middle part.

The sandstone is coarse-grained and poorly sorted. The major composition of twenty four specimens is shown in Table 1. The average composition of sand grains is: quartz 35.3, feldspar 47.3 and rock fragments 17.4. The feldspars include plagioclase, orthoclase, microcline and perthite. The plagioclase is andesine-labradorite in composition. Rock fragments consist mainly of volcanic rocks (as much as 91.1 percent of the whole fragments), subordinately of granitic, sedimentary and metamorphic rocks. Sixteen of the specimens belong to feldspathic wacke (with the matrix of 24.1 percent), six to feldspathic arenite (12.9 percent matrix) and the rest to lithic arenite (13.4 percent matrix) and lithic wacke (33.0 percent matrix).

Most of the limestones are well-sorted crinoid-fusuline biosparrudite to biopseudosparrudite. However, those of the northern part of the outcropping area of the formation, are largely recrystallized into coarse-grained pseudosparite and pseudomicrite (see Pl. 59, Figs. 1, 2).

The limestone occurs at three horizons in the lower part and the following fusulines have been obtained:

Lower limestone lenses:

Quasifusulina sp.

Schwagerina sp. B

S. $\quad$ sp. C

Pseudofusulina spp.

Paraschwagerina plicata (LEE)

Pseudofusulina regularis (SCHELLWIEN)

$P$.

$\mathrm{sp.}$

$P$.

spp.

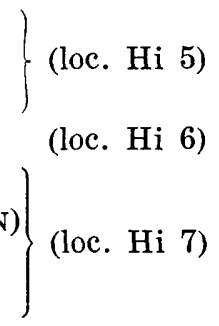

Middle limestone lenses:

Pseudoschwagerina sp.

Schwagerina sp. A

Pseudofusulina sp. B

Eoparafusulina sp.

Pseudoschwagerina sp.

Schwagerina sp. A

Pseudofusulina aff. krotowi

(SChELlWIEN)

$P$.

spp.

Eoparafusnlina sp.

Pseudofusulina spp.

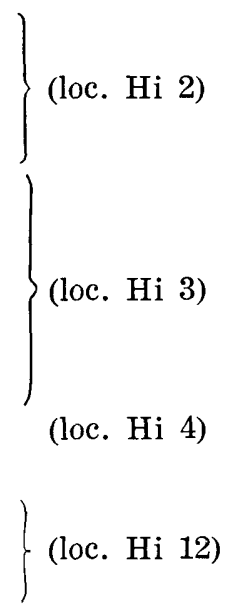

Upper limestone lenses:

Pseudofusulina sp. A

Misellina sp.

Verbeekina sp. 


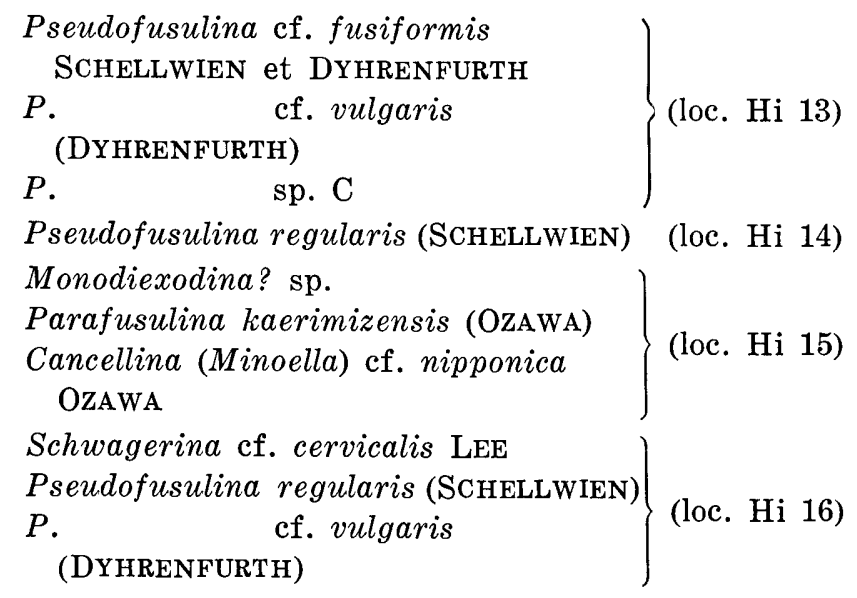

The species listed above indicate that the lower part of the formation ranges from the Pseudoschwagerina morikawai zone to the Neoschwagerina simplex zone.

\section{Nakakubo Formation}

The name Nakakubo 'Group' was first introduced by HIRATA (1958) to the strata distributed in the area of the Nakakubo river and its tributaries, about $4 \mathrm{~km}$ east of the surveyed area. It was studied by IsHIZAKI (1962). The formation is extended westerly to the eastern side of the Masagoya valley and the vicinity of Yanadani and Mt. Maruishi.

The formation is unconformably overlain by the Masagoya Formation. It is in fault contact with the Oonogahara Formation on the southern side. It is composed predominantly of basic rocks, with some intercalation of alternating sandstone and slate, and chert. The basic rocks include gabbro, microgabbro, basalt and tuff and are locally accompanied by limestone breccia.

From the surveyed area Pseudofusulina sp. ex. gr. P. ambigua (DEPrat) has been newly found from a limestone breccia bed at loc. Od. 103. The bed consists of angular blocks of cobble to boulder size and of different textures with a tuff matrix. From certain other limestones and limestone breccias of the formation, the species of the Fusulinella Zone to the Pseudoschwagerina Zone were reported by previous workers:

Nankinella sp., Eoschubertella obscura (LEE et CHEN), Fusulinella asiatica IGo, F. pseudobocki (LEE et CHEN), Triticites cylindrica (FISHER DE WALDHeime), T. parvus Chen, T. pseudosimplex (Shellwien), T. sp., Schubertella cf. kingi DUNBAR and SKINNER, Paraschwagerina (Acervoschwagerina) endoi HANZAWA, Rugosofusulina sp., Schwagerina cf. minuta Thompson, S. sp., Pseudofusulina japonica (GUMBer), $P$. tschernyschewi (SchellwIEN), $P$. chihsiaensis LeE, $P$. cf. aganoensis HuJimoto, $P$. cf. gregaria LeE and $P$. cf. parvula (SCHELlWIEN) [KASHIMA, 1960].

Spirifer sp., Squamularia sp., Rhynchonella sp., Enteletes? sp., Meekella? sp., Leptaena sp. and Pleurotomaria? sp. [HiRATa, 1961]. 
Bradyina nautiliformis shikokuensis ISHIZAKI, Climacammia cf. valvulinoides LANGE, Cribrostmum eximium EICHWARD, Triticites spp., Schwagerina tintensis ROBERT, S. tschernyschewi (SCHELLWIEN), S. cf. pseudobrevicula (DEPRAT), Pseudofusulina declinata Kozhenevski, $P$. cf. alpina vetusta (Schellwien), P. alpina var. vetusta (Schellwien), P. ambigua (DEPRAT), $P$. spp. and Paraschwagerina (Acervoschwagerina) sp. [ISHIZAKI, 1962].

These breccia are considered to have been formed as penecontemporaneous talus deposits derived from the limestone beds on the flanks or slopes of submarine volcanic mounds. The above mentioned fossils do not show the age of the deposition of the limestone breccias. It is, however, clear that the limestone breccia is not older than the Pseudofusulina ambigua zone.

\section{Nomura Formation}

The Nomura Formation was first established by IKEBE (1936) for the Palaeozoic strata distributed in the vicinity of Nomura, and later studied by NAKAGAWA et al. (1959) who restricted the name Nomura Formation to the southern half of the distribution excluding the northern half as the Itadorigawa, Onji and Doi Formation. The western extention of the formation is distributed in the area of Shirahige.

The formation, which is about $1300 \mathrm{~m}$ in total thickness, consists mainly

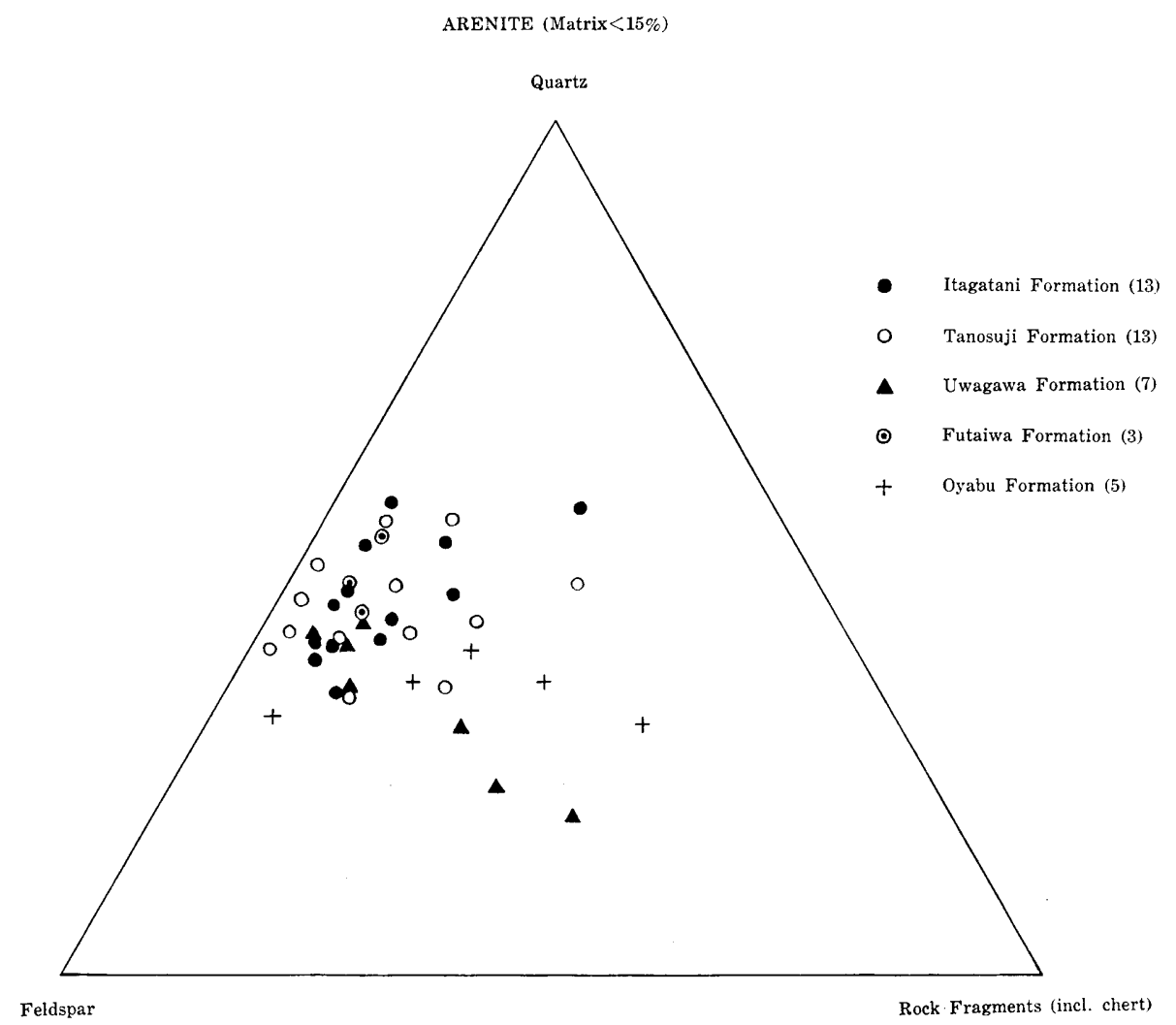

Fig. 6. Compositional diagram of the sandstones. 
of alternating sandstone and slate with some intercalations of chert, limestone and conglomerate. Lava flows of 2 to $3 \mathrm{~m}$ thick occur at two levels. The lava of the lower level is andesitic and that of the upper is spilitic basalt.

Only one specimen of the sandstone has been petrologically examined. The composition of sand grains is as follows: quartz 50.0, feldspar 44.8, and volcanic and chert fragments 5.2 percent. The feldspars include plagioclase of andesine to labradorite and orthoclase. It belongs to feldspathic wacke (29.5 percent matrix).

A limestone found at Uchiba is recrystallized to coarse grained pseudosparite. The limestones at other localities are made up of micritic matrix and cut by calcite veinlet.

From some limestone lenses of the formation in the Nomura and Uonashi areas the following fossils have been reported by previous investigators:

Neoschwagerina sp. [Tatsuo SuzUKI, 1935], Neoschwagerina craticulifera Schwager, N. simplex Ozawa, Verbeekina verbeeki (GeINITz), Staffella? sp., Bigeneria sp., Glomospira? sp., Lonsdaleia cf. katoi OzAWA, L. sp., Chaetetes sp. and Mizzia velebitana SchUBERT [IKEBE, 1936].

These indicate that the limestones are undoubtedly assigned to the $\mathrm{NeO}$ schwagerina craticulifera zone. The following species have also been collected by myself from the limestone lenses in the Tanosuji area.

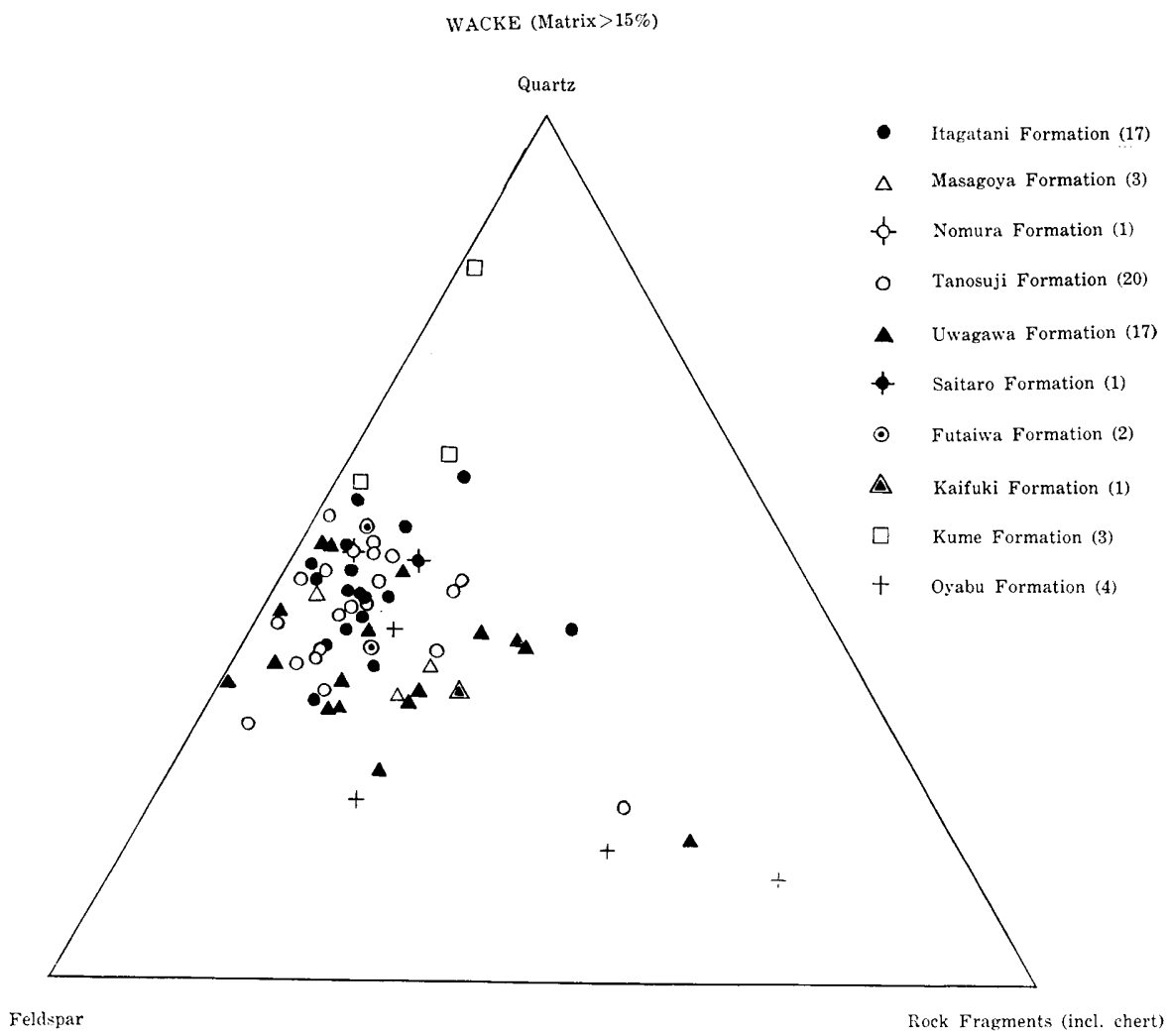

Fig. 7. Compositional diagram of the sandstones. 
Pseudodoliolina sp.

Yabeina cf. globosa (OzAWA)

(loc. Hi 19)

(loc. Hi 22)

Thus the Nomura Formation ranges from the Neoschwagerina craticulifera zone to the Yabeina globosa zone.

\section{Masagoya Formation}

The Masagoya Formation, which was preliminarily studied by KASHIMA and MiYAHISA (1968), is typically exposed on the left side of the Masagoya valley. It is thrust by a belt of the Odamiyama Formation on its north side. The thickness of the exposed part is $970 \mathrm{~m}$.

The formation disconformably rests on the Nakakubo Formation on its south side. The basal part is composed of slate, with scattered rounded pebbles of chert and volcanic rocks and also cobbles and boulders of limestone.

The main part of the formation consists of sandstone and slate with several lava flows of basic rock and bed of chert. The major detrital composition of sandstone is as follows (average percentage of three specimens) : quartz 38.6, feldspar 47.1 and rock fragments 14.3. The feldspars consist of plagioclase and orthoclase, of which the former is of andesine. The rock fragments are mainly of volcanic rocks (as much as 98.1 percent of the fragments) and debris of chert. It belongs to feldspathic wacke (25.1 percent matrix).

Table 2. Average composition of the rock fragments in sandstones (in percentage)

\begin{tabular}{l|r|r|r|r|r}
\hline \multicolumn{1}{c|}{ Formation } & chert & $\begin{array}{c}\text { granitic } \\
\text { rocks }\end{array}$ & $\begin{array}{c}\text { volcanic } \\
\text { rocks }\end{array}$ & $\begin{array}{c}\text { sedimentary } \\
\text { rocks }\end{array}$ & $\begin{array}{c}\text { metamorphic } \\
\text { rocks }\end{array}$ \\
\hline Itagatani & 5.6 & 4.1 & 77.6 & 6.5 & 6.2 \\
Masagoya & 1.9 & 0 & 98.1 & 0 & 0 \\
Nomura & 23.1 & 0 & 76.9 & 0 & 0 \\
Tanosuji & 11.8 & 2.3 & 78.2 & 3.7 & 4.0 \\
Uwagawa & 3.8 & 1.0 & 91.1 & 2.7 & 1.3 \\
Saitaro & 1.8 & 0 & 94.5 & 3.6 & 0 \\
Futaiwa & 5.5 & 12.0 & 77.5 & 4.9 & 0 \\
Kume & 0 & 0 & 100.0 & 0 & 0 \\
Kaifuki & 7.9 & 0 & 90.5 & 1.6 & 0 \\
Oyabu $\{$ lower & 4.4 & 0.9 & 88.6 & 5.9 & 0.2 \\
& 2.8 & 0 & 98.1 & 1.9 & 0 \\
\hline
\end{tabular}

The lavas are those of dolerite, spilite and basalt. They are associated with some limestone lenses. From fusuline biosparrudite lenses the following fusuline fossils were obtained:

Yabeina globosa (OzAWA)

$Y$. katoi (OzAWA)

\} (loc. Od 102)

Thus the formation belongs to the upper Middle Permian Yabeina globosa zone. 


\section{Triassic System}

1. Uonashi Formation

The Uonashi Formation is distributed in a narrow belt along the Uonashi thrust and another belt along the Kurosegawa tectonic zone. It is always faulted against the adjacent strata.

The formation, about $30 \mathrm{~m}$ thick, consists of limestone, dolomitic limestone, dolomite and conglomerate.

The limestone at Taho is dolomitized biomicrudite and biomicrite. It consists innumerable and extremely thin shells probably of pelagic (Bositra) bivalves and abundant radiolarian remains. The matrix is largely or completely replaced by dolomite (see Pl.60, Fig. 1). From this limestone the Lower Triassic (Scythian) Bivalvia and Cephalopoda were previously reported (YEHARA, 1926a, b; SHIMIZU and Jimbo, 1933; IKEBE, 1936 and BANDo, 1964).

At Kakinoki a conglomerate made up of pebbles and cobbles of dolomite, limestone, chert and slate is exposed.

Neoschwagerina (Gifuella) sp. is found in the limestone pebbles.

\section{Jurassic System}

\section{Imaidani Formation}

The Imaidani Formation, named by IcHIKAWA et al. (1954), is distributed in a narrow belt extending from Imaidani westward to Nagatani. The belt is bounded by the Uonashi thrust on the north side and by the Kootoshi fault on the south.

The formation is divided into the lower, Oriai and the upper, Nakatsugawa subformation (ICHIKAWA et al., 1956). In the surveyed area only the Oriai subformation is exposed which consists mainly of mudstone and sandstone, with limestone of the so-called Torinosu type.

The major composition of the two sandstone samples is shown in Table 1. One of them (65032710) belongs to feldspathic arenite (12.7 percent matrix) and the other to feldspathic wacke (17.9 percent matrix). The feldspars are composed of plagioclase, orthoclase, microcline and perthite. The rock fragments consist mainly of volcanic rocks.

A limestone at Nagatani is poorly sorted, highly mixed biosparudite. The contained fossil fragments are crinoid ossicles, echinoderm spines and plates, brachiopod shells, stromatoporoid, gastropods, dasycladacean and codiasian algae. Another limestone at Kootoshi is pelmicrite with authigenic feldspar.

A large number of various groups of fossils have been recorded from the Imaidani Formation by previous investigators (YABE and SugIYAMA, 1930-35; Tatsuo Suzuki, 1935; Nakagawa et al., 1959 and Tamura, 1960), on the basis of which the formation has been referred to the Upper Jurassic.

\section{Tanohama Formation (?)}

The strata probably referable to the Tanohama Formation are exposed in a limited, narrow belt of the Kuroiji area, bounded by faults. They are strongly 
folded with axes of the east-west direction.

The formation consists of sandstone, muddy sandstone and shale, with lenticular bodies of limestone.

No fossils have been found from this area, however, the lithofacies and stratigraphic relationship suggest that the formation is probably an extension of the Tanohama Formation of an Upper Jurassic age, the type locality of which is about $17 \mathrm{~km}$ west of Tanohama area (NAGAI and KASHIMA, 1963).

\section{E. Itagatani Formation of Uncertain ages}

The strata of the Sambosan belt along the northern side of the Butsuzo tectonic line have been locally called in various names in western Shikoku, that is, the Takagawa Formation (IcHIKAwA et al., 1954) in the Takagawa area, the Itagatani Formation (IKEBE, 1936) in the Itagatani area, the Tawarazu Formation (HIRAYAmA and KAmBe, 1956) in the Tawarazu area, and the Higashiuwa Formation (BANDo, 1964) in the Nomura area. These names were given to parts of one and the same formation, as can be understood from the descriptions of the lithologic assemblage, facies, and the structural position. The name of Itagatani Formation is adopted in this paper by priority.

The Itagatani Formation occupies the southernmost part of the Chichibu belt in this area. It is bounded by the Butsuzo tectonic line against the Shimantogawa Group of Cretaceous to Lower Tertiary ages on the south side.

The formation forms an isoclinal anticline structure, and attains a thickness of approximately $840 \mathrm{~m}$ on the northern wing. On the southern wing it is exposed in a narrow belt along the Butsuzo tectonic line where it consists of basalt, basaltic tuff, agglomerate, limestone, chert, sandstone and slate. On the northern wing it consists mainly of chert, sandstone, slate and is associated with some beds of basaltic tuff and limestone. Banded and massive bodies of chert are common and occasionally contain manganese ore deposits which belong to the Manako type of Yoshimura (1952).

The average framework composition of thirty sandstone specimens is quartz 44.9, feldspar 44.9 and rock fragments 10.2 percent. The feldspars consist of labradoritic plagioclase, orthoclase, microcline and perthite. The rock fragments are mainly of volcanic rocks (77.6 percent of the fragments) with some amounts of sedimentary, granitic and metamorphic rocks. The debris of metamorphic rocks are composed of phyllite, biotite-quartz schist and others. Most of the sandstones belong to feldspathic arenite (12.8 percent matrix) and feldspathic wacke (22.0 percent matrix).

A limestone at Kannonsui is made up of dolomitized and silicified pelagic pelecypod biomicrudite. The one at Hanaga-pass is algal biomicrite. From a limestone bed at Yasumori (loc. Hi 24) Stromatomorpha sp. has been collected.

A few fossils have been reported by previous workers from some other localities: Neoschwagerina sp. and Schwagerina sp. (Tatsuo SUZUKI, 1935): Stromatopora (Parastromatopora) japonica YABE and SUGIYAMA (YABE and SugIYAma, 1930-35). The siliceous slate and chert in the Itagatani area contain abundant radiolarin remains (see ( $\mathrm{Pl} .59$, Fig. 4). 


\section{Palaeontological Description of Selected Species}

The Palaeozoic strata of the present area are not only strongly folded and faulted, but also remarkably cleaved in general, even metamorphosed to semischist in part. They are of eugeosynclinal lithologic assemblage, and show a remarkable change in facies. Therefore without the aid of fossils, it is difficult to elucidate their stratigraphy and geologic structure. Despite several previous works, no fossils have hitherto been described in them.

The fusuline fossils newly found from several limestones of the present area are, with a few exceptions, extremely poor in preservation, having been strongly deformed. Limestones of more or less metamorphosed strata in the northern part of the surveyed area are almost completely recrystallized and strongly foliated. In fact fusulines fortunately obtained from such crystalline and foliated limestones are squashed and elongated to thin films or streaks when they are seen in the planes perpendicular to the foliation, and were found only in sections which were cut parallel to the foliation plane. Such a highly compressed specimen must show a shell-shape much different from its primary one.

Thus the poor preservation of the obtained material has given a great difficulty for the precise identification of species. Most of the specimens are, however, accessible for the generic assignment and may be admitted to the specific comparison.

The obtained fusulinacean fossils are listed in Table 3, of which some selected species which are useful in age determination are described here.

\section{Description of species}

Order Foraminiferida Eichwald, 1830

Superfamily Fusulinacea von MöLLER, 1878

Genus Fusulinella MöLleR, 1877

Fusulinella n. sp. (?) aff. F. hirokoae SUYARI

Pl. 54, Figs. 1-3

\section{Compare.- \\ 1962. Fusulinella hirokoae SUYARI, Jour. Gakugei, Tokushima Univ., Nat. Sci., Vol. 12, p. 13-14, pl. 3, figs. 9-13. \\ 1964. Fusulinella hirokoae, SADA, Geol. Repts. Hiroshima Univ., Ser. C, Vol.4, No. 3, p. 239-240, pl. 23, figs. 12-15.}

Material.-Reg. no. GE 6, 7, 8, 9, 10, 11, 12,13,14, 15, 16, 17, 18, 19, 20, $21,22,23$ and 24.

Description.- Shell moderately large for the genus, fusiform to elongate fusiform with a slightly inflated median region and rounded poles. Mature shells have five to six volutions.

Axial length 2.00 to $2.80 \mathrm{~mm}$, median width 0.92 to $1.08 \mathrm{~mm}$ and form ratio 2.17 to 2.59. First and second volutions spherical, closely coiled and outer volutions rapidly increase in height. Height of first to fourth volution average 
55, 66, 114 and 160 microns, respectively for eleven specimens. Proloculus small, spherical; its inside diameter 31-62 microns, averaging 49 microns for eleven specimens.

Spirotheca thin, typical for the genus in structure. Average thickness of first to fourth volution in ten specimens $16,22,30$ and 37 microns, respectively. Septa rather widely spaced, unfluted in the central region, but weakly fluted in the polar regions.

Chomata low, massive, less than half as high as the chambers. Their tunnel sides steep but polewards slopes gentle. Tunnel narrow in the inner volutions but rapidly increase to 43 degrees in the outer ones.

Remarks.-In the general shell-shape this species resembles Fusulinella hirokoae SUYARI from the Daigo Formation in Shikoku, Japan, but it differs in having a smaller shell and a smaller form ratio. The obtained specimens have a small number of volutions and are all completely encrusted by stromatolitic calcareous algae. They may have been more or less abraded, but no specimens are comparable in the shell size with $F$. hirokoae. This suggests that they are specifically different from the latter.

It also resembles $F$. delepinei vaN GINKEL from the Cantabrian mountains, Spain, but is distinguishable by its smaller and relatively more elongate shell with less convex lateral sides and less numerous volutions.

Occurrence.-Abundant at loc. Hi 9 in the Oyabu Formation. Associated species are shown in Table 3.

Genus Beedeina GaLloway, 1933

Beedeina lanceolata (LEE et CHEN)

Pl. 54, Figs. 4-6

1930. Girtyina lanceolata LeE et Chen, Mem. Nat. Res. Inst. Geol., No.9, p. 134-135, pl. 13, figs. 5-6.

1944. Fusulina lanceolata, Toriyama, Jap. Jour. Geol. Geogr., Vol.19, Nos.1-4, p. 75-76, pl. 6, figs. 14-15.

1957. Fusulina lanceolata, IGo, Tokyo Univ., Education, Sci. Rep., Sec. C, Vol.5, p. 214-215, pI. 10, figs. 1-10.

1958. Fusulina lanceolata, Sheng, Palaeontologia Sinica, N. S. B, No. 7, p. 39, pl. 11, figs. 17-18; pl. 12, figs.1-3.

Material.-Reg. no. GE 1, 2, 3, 4 and 5.

Description.-Shell small, at first subspherical, and later (from the third volution) elongate fusiform. Poles bluntly pointed. Mature shell of five and a half volutions attains an axial length of $3.80 \mathrm{~mm}$ and a median width of $1.56 \mathrm{~mm}$, giving a form ratio of 2.44 . Average height of first to fifth volution in four specimens 63, 78, 99, 144 and 211 microns, respectively. Proloculus small, spherical; its inside diameter 117-139 microns, averaging 129 microns for four specimens.

Spirotheca consists of a tectum, a diaphanotheca and upper and lower tectoria. Its thickness attains 47 microns in the outer volutions. Septa numerous and rather irregularly fluted throughout the length of the shell. Chomata well developed and symmetrical. Tunnel narrow and straight. 
Remarks.-The present specimens are more or less deformed, but they are identical with the types of Beedeina lanceolata (LEE et CHEN) in many diagnostic features. Beedeina ichinotaniensis and $B$. ichinotaniensis rotundata established by IGo (1957) from the Ichinotani Formation of central Japan are also closely allied to $B$. lanceolata. IGo distinguished them from one another on the basis of minor differences, but the writer considers that they are probably within variation of one and the same species.

Occurrence.-Common at loc. Hi 9 in the Oyabu Formation. Associated species are shown in Table 3.

\author{
Family Schwagerinidae Dunbar and HENBEST, 1930 \\ Genus Triticites GIRTY, 1904 \\ Triticites sp. ex gr. T. yayamadakensis KANMERA \\ Pl. 55, Figs. 7-9
}

Material.-Reg. no. GE 73,74 and 75 .

Descriptive remarks.-One sagittal section and two oblique sections are before me. The specimens have at least four and a half volutions. Shell tightly coiled in the inner two or three volutions but rather rapidly expanded in the outer ones.

Proloculus small, and spherical, with its inside diameter of 78 microns. Height of the first to the fourth volution 62, 62, 125 and 265 microns, respectively in a specimen, reg. no. GE 75 (Pl. 55, Fig. 9).

Spirotheca thin, consisting of a tectum and a finely alveolar keriotheca. Its thickness measures 16, 16, 39 and 47 microns in the first to the fourth volution, respectively. Septa rather loosely spaced in the outer volutions, and unfluted in the central part of the shell. Septal counts of the first to the fourth volution $8,13,16$ and 16 , respectively.

These specimens seem to be placed in the genus Triticites, but the specific identification is impossible owing to the lack of axial sections. The present sagittal section, however, closely resembles those of Triticites yayamadakensis in the number of septa and the mode of coiling.

Occurrence.-Rare at loc. Hi 17 in the Kaifuki Formation. No other fusulinaceans are associated.

Genus Pseudoschwagerina DUnbar and SkINNER, 1936

Pseudoschwagerina minatoi KANMERA

Pl. 55, Figs. 5-6

1958. Pseudoschwagerina minatoi KanMera, Mem. Fac. Sci., Kyushu Univ., Ser. D, Vol. 6, No. 3, p. 179-181, pl. 28, figs. 1-8.

Material.-Reg. no. GE 76, 77, 78, 79, 80, 81 and 82 .

Description.-Shell globular to subspherical, with bluntly pointed poles. It has six to seven volutions. The inner three volutions fusiform and very closely coiled, but beyond the third volution the shell expands rapidly and the last volution decreases in height. Height of volutions of probably fifth and sixth 
volution attains $700-800$ microns.

Spirotheca thin for the genus, consisting of a tectum and a keriotheca with fairly coarse alveoli. Its thickness ranges from 16 microns in the inner volutions to 31 microns in the outer ones. Septa thin, irregularly and weakly fluted throughout the length of the shell.

Septal counts of the second to the fifth volution of three specimens 16, 21, 27 and 29 , respectively. Chomata poorly developed adjacent to the septa. Tunnel narrow and straight.

Remarks.-The obtained specimens are incomplete and not well oriented, but a direct comparison with the types of Pseudoschwagerina minatoi KANMERA confirms the specific identification. The species is similar to Pseudoschwagerina wongwenhaoi (LEE) from the Hsiaoching Limestone in North China, but it has a thinner spirotheca, smaller number of volution and a more minute proloculus.

Occurrence.-Common at loc. Hi 23 in the Tanosuji Formation. Associated species are shown in Table 3.

Genus Paraschwagerina DUNBAR and SkINNER, 1931

Paraschwagerina plicata (LEE)

Pl. 54, Fig. 9

1927. Pseudofusulina plicata Lee, Palaeontologia Sinica, Ser. B, Vol.4, Fasc.1, p. 92-94, pl. 15, figs. 12-16.

1955. Pseudofusulina plicata, Morikawa, Sci. Rep., Saitama Univ., Ser. B, Vol.2, No. 1, p. 85-86, pl. 8, figs. 1-6.

Material.-Two diagonal and two oblique sections are at my disposal. Reg. no. GE $85,86,87$ and 88 .

Description.-The outline of the axial section not known. The shell is large and has at least seven volutions. Shell tightly coiled in the inner three or four volutions and rapidly increases in height in the outer volutions.

Proloculus minute and its inside diameter 94 to 140 microns. Spirotheca consists of a tectum and a coarsely alveolar keriotheca. Spirotheca very thin in the inner volutions, about 31 microns, and increases in thickness in the outer ones to attain nearly 140 microns. Septa thin and intricately fluted throughout the shell.

Remarks.-The present specimens are not well oriented, but they are identical in many features with the types of Paraschwagerina plicata (LEE).

Occurrence.-Rare at loc. Hi 7 in the Uwagawa Formation. Associated species are shown in Table 3.

Schwagerina? sp. or Pseudofusulina? sp.

Pl. 55, Fig. 10

Descriptive remarks.-Only one oblique section (reg. no. GE 103) was obtained. This specimen is strongly compressed to the direction perpendicular to the sectioned plane, so that it must have a less inflated shell shape. Spirotheca largely recrystallized, but the unaltered part shows a structure consisting 
of a tectum and an alveolar keriotheca. Septa relatively thin and strongly fluted. The present specimen is referable to either Schwagerina or Pseudofusulina. Occurrence.-A single specimen found at loc. Hi 1 in the Saitaro Formation. No other fusulinaceans are associated.

\section{Genus Parafusulina Dunbar and Skinner, 1931 \\ Parafusulina kaerimizensis (OzAWA) \\ P1. 54, Figs. 7-8}

1925. Schellwienia kaerimizensis (OzAwA), Jour. Coll. Sci., Imp. Univ. Tokyo, Vol. 45, Art. 6, p. 31-32, pl. 4, figs. 6-7; pl. 6, fig. 5.

1936. Pseudofusulina kaerimizensis, Hujıмoтo, Sci. Rep., Tokyo Bunrika Daigaku, Ser. C, No. 2, p. 65-67, pl. 7, figs. 6-7.

1955. Parafusulina kaerimizensis, MonIKawa, Sci. Rep., Saitama Univ., Ser. B, Vol. 2, No. 1, p. 107-108, pl. 15, figs. 11-13.

1957. Parafusulina kaerimizensis, Kobayashi, Sci. Rep., Tokyo Kyoiku Daigaku, Ser. C, No. 48, p. 291, pl. 7, fig. 1 .

1958. Parafusulina kaerimizensis, ToriYama, Mem. Fac. Sci., Kyushu Univ., Ser. D, Vol. 7, p. 194-197, pl. 30, figs. 6-12; pl. 31, figs. 1-8; pl. 32, figs. 1-9.

1959. Parafusulina kaerimizensis, KanUma, Bull. Tokyo Gakugei Univ., Vol. 10, p. 81-82, pl. 9, figs. 1-3.

1962. Parafusulina kaerimizensis, SUYARI, Jour. Gakugei, Tokushima Univ., Nat. Sci., Vol. 12, p. 28-29, pl. 9, fig. 5 .

1963. Parafusulina kaerimizensis, Kanmera, Mem. Fac. Sci., Kyushu Univ., Ser. D, Vol. 14, No. 2, p.101-102, pl.16, figs. 6-7; pl.17, figs. 5-7; pl.18, figs. 5-8.

Material.-Reg. no. GE 156, 157, 158, 159, 160, 161, 162 and 163.

Description.-Shell large, elongate subcylindrical, with a straight axis of coiling and bluntly pointed poles. Shell has at least six volutions.

The approximate measurements give an axial length of $12 \mathrm{~mm}$ and a median width of $2.7 \mathrm{~mm}$. Proloculus large, subspherical. The volution increases in height uniformly. Spirotheca consists of a thin tectum and a keriotheca with coarse alveoli. Its thickness of the first to the sixth volution $47,47,62,70,94$ and 109 microns, respectively.

Septa thin, closely spaced, narrowly and highly fluted throughout the length of the shell. Septal counts of the first to the fourth volution in two specimens 6-7, 17-18, 25-27 and 30, respectively. Axial fillings wide and dense.

Remarks. - The specimens referred to the present species are strongly deformed, and give varied apparent features depending on the direction of the section. But they are considered to belong to one and the same species.

The characteristics of the present sepcimens are the elongate cylindrical shell shape, the intense septal fluting and dense axial fillings. In these respects the specimens are closely similar to the types of Parafusulina kaerimizensis (OzAWA) and are considered to be referred to it.

Occurrence.-Common at loc. Hi 15 in the Uwagawa Formation. Associated species are shown in Table 3. 


\author{
Genus Cancellina HAYDEN, 1909 \\ Cancellina (Minoella) cf. nipponica OzAWA \\ Pl. 54, Fig. 11
}

Compare.-

1927. Cancellina nipponica OzAwA, Jour. Fac. Sci. Imp. Univ. Tokyo, Sec. 2, Vol. 2, Pt. 3, p. 160-161, pl. 34, figs. 12-17; pl. 35, figs. 8b, 10a; pl. 44, fig. 1a; pl. 45, figs. 4-5.

1959. Neoschwagerina (Minoella) nipponica, HonJo, Jour. Fac. Sci. Hokkaido Univ., Ser. 4, Vol. 10, p. 124-127, pl. 1, figs. 6-8, 10.

1959. Neoschwagerina (Minoella) nipponica, Minato and HoNJo, Ibid., p. 325326.

1961. Neoschwagerina nipponica, Morikawa and Suzuki, Sci. Rep. Saitama Univ., Ser. B, Vol. 4, No. 1, p. 49, pl. 4, figs. 1-4; pl. 12, figs. 4-6.

1961. Neoschwagerina nipponica, Morikawa and Isomi, Geol. Surv. Japan, Rep. No. 191, p. 26-27, pl. 20, figs. 15-19.

Material.-One parallel section, reg. no. GE 173, is available.

Description.-Shell small, with at least six volutions. Height of the outer volutions ranges from 90 to 125 microns. Spirotheca thin, ranging in thickness from 16 to 23 microns. Spirotheca consists of a tectum and a finely alveolar keriotheca. Axial septula appear in the outer volutions.

Remarks.-The material is insufficient for the specific identification, but the present specimen closely resembles the types of Cancellina nipponica OzAWA in the small shell and thin spirotheca, septa and septula. It is probably referable to $C$. nipponica Ozawa.

Occurrence.-Only one specimen found at loc. Hi 15 in the Uwagawa Formation. Associated species are shown in Table 3.

\title{
Genus Yabeina DePRAT, 1914 \\ Yabeina globosa (OzAWA)
}

Pl. 55, Figs. 1-2

1925. Neoschwagerina globosa OzAWa, Jour. Sci. Coll., Imp. Univ. Tokyo, Art. 4, pl. 3, fig. 5 .

1927. Neoschwagerina globosa OzaWA, Jour. Fac. Sci., Imp. Univ. Tokyo, Ser.2, p. 156-160, pl. 41, figs. 2,9 ; pl. 42, figs. $1-2,4$, 6; pl. 43, figs. 1 b, 4.

1936. Yabeina globosa, Huлıмото, Sci. Rep. Tokyo Bunrika Daigaku, Ser. C, No. 2, p. 119-121, pl. 24, fig. 9; pl. 25, figs. 1-4.

1961. Yabeina globosa, MorikaWA and SuzukI, Sci. Rep. Saitama Univ., Ser. B, Vol. 4, No.1, p. 67-68, pl.10, fig. 2; pl. 21, fig. 1.

1963. Yabeina globosa, SUYARI, Jour. Gakugei, Tokushima Univ., Nat. Sci., Vol. 12, p. 37-38, pl. 12, fig. 1.

Material.-Reg. no. GE 178, 179, 180, 181, 182 and 183.

Description.-Shell large, globular to inflated fusiform with a nearly straight axis of coiling and rounded poles. The mature specimens have twenty one to twenty three volutions. A globular shell (reg. no. GE 178) attains an axial length of $8.3 \mathrm{~mm}$ and a median width of $6.3 \mathrm{~mm}$, giving a form ratio of 1.3. An inflated fusiform shell (reg. no. GE 180), which seems to be slightly 
deformed, attains an axial length of $6.4 \mathrm{~mm}$ and a median width with $3.6 \mathrm{~mm}$, giving a form ratio of 1.8 .

Proloculus minute, spherical to subspherical. The inside diameter of the proloculus in four well-centered specimens is $39-86$ microns and averages 68 microns. Height of the first to the twenty third volution $25,29,37,41,62,57$, $90,98,123,127,127,127,120,127,139,151,151,172,172,189,160,176$ and 197 microns, respectively.

Spirotheca thin, ranging in thickness from 4 to 12 microns. Spirotheca consists of a tectum and a keriotheca with very fine alveoli. Primary transverse septula present throughout the length of the shell. The thickness of the middle part of primary transverse septula from 31 to 78 microns and averages 47 microns in the tenth volution. Secondary transverse septula first appear in the sixth volution. There are 3-7 septula between the septa in the outer volutions. Rather low parachomata are present throughout the length of the shell.

Remarks.-On account of the characteristic features, such as minute proloculus, a globular shell shape, thick transverse and axial septula and low parachomata, as well as measurement of the shell, the described specimens are referred to Yabeina globosa (OzAWA).

Occurrence.-Abundant at loc. Od 102 in the Masagoya Formation. Associated species are shown in Table 3 .

\section{Yabeina katoi (OzAWA)}

Pl. 55, Figs. 3-4

1927. Neoschwagerina katoi Ozawa, Jour. Fac. Sci., Imp. Univ. Tokyo, Vol. 2, Pt. 3, p. 159, pl. 41, figs. 1-10; pl. 42, fig. 3; pl. 43, figs. 1a, 2a, 3, 5-6.

1936. Neoschwagerina katoi, Hujıмoto, Sci. Rep. Tokyo Bunrika Daigaku, Sec. C, No. 2, p. 118-119, pl. 24, figs. 5-6.

1957. Yabeina cf. katoi, KobaYASHI, Sci. Rep. Tokyo Kyoiku Daigaku, Ser. C, No. 48, p. 308-309, pl. 10, fig. 7 .

1961. Yabeina katoi, MoRIKAWA and Suzuki, Sci. Rep. Saitama Univ., Ser. B, Vol. 4, No. 1, p. 68-69, pl. 10, fig. 1; pl. 21, figs. 2-3.

Material.-Reg. no. GE 174, 175, 176 and 177.

Description.-Shell large, globular to inflated fusiform, with a nearly straight axis of coiling and rounded poles. The mature specimens have twenty to twenty one volutions. A large inflated fusiform shell (reg. no. GE 174) attains an axial length of $6.3 \mathrm{~mm}$ and a median width of $3.9 \mathrm{~mm}$, giving a form ratio of 1.6. Proloculus minute, its inside diameter 47 microns.

Height of the first to the twentieth volution $62,70,78,78,86,109,109,133$, $140,140,156,156,156,140,147,180,156,172,147$ and 156 microns, respectively. Spirotheca thin, ranging in thickness from 8 to 16 microns. Spirotheca consists of a tectum and a very finely alveolar keriotheca. Primary transverse septula occur throughout the length of the shell. They are characteristically thin, ranging in thickness of the middle part from 16 to 47 microns and averages 20 microns in the tenth volution. Secondary transverse septula appear in the sixth to eighth volution and well developed in the outer ones. Axial septula thin and short. 
Table 3. Distribution of the fusulinacean

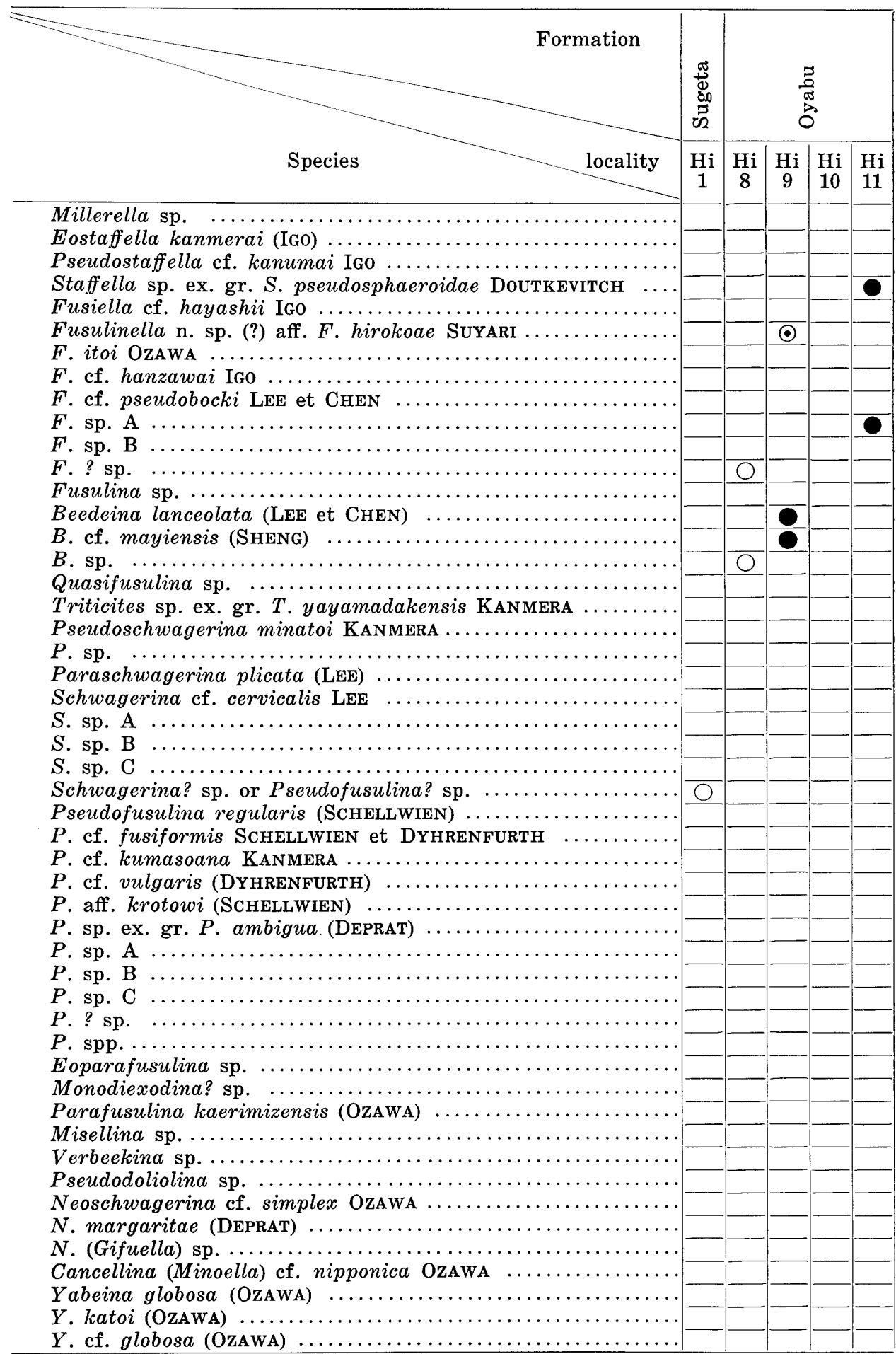

Explanation: $\odot$ abundant, $\bigcirc$ common, $\bigcirc$ rare 
species in western Shikoku

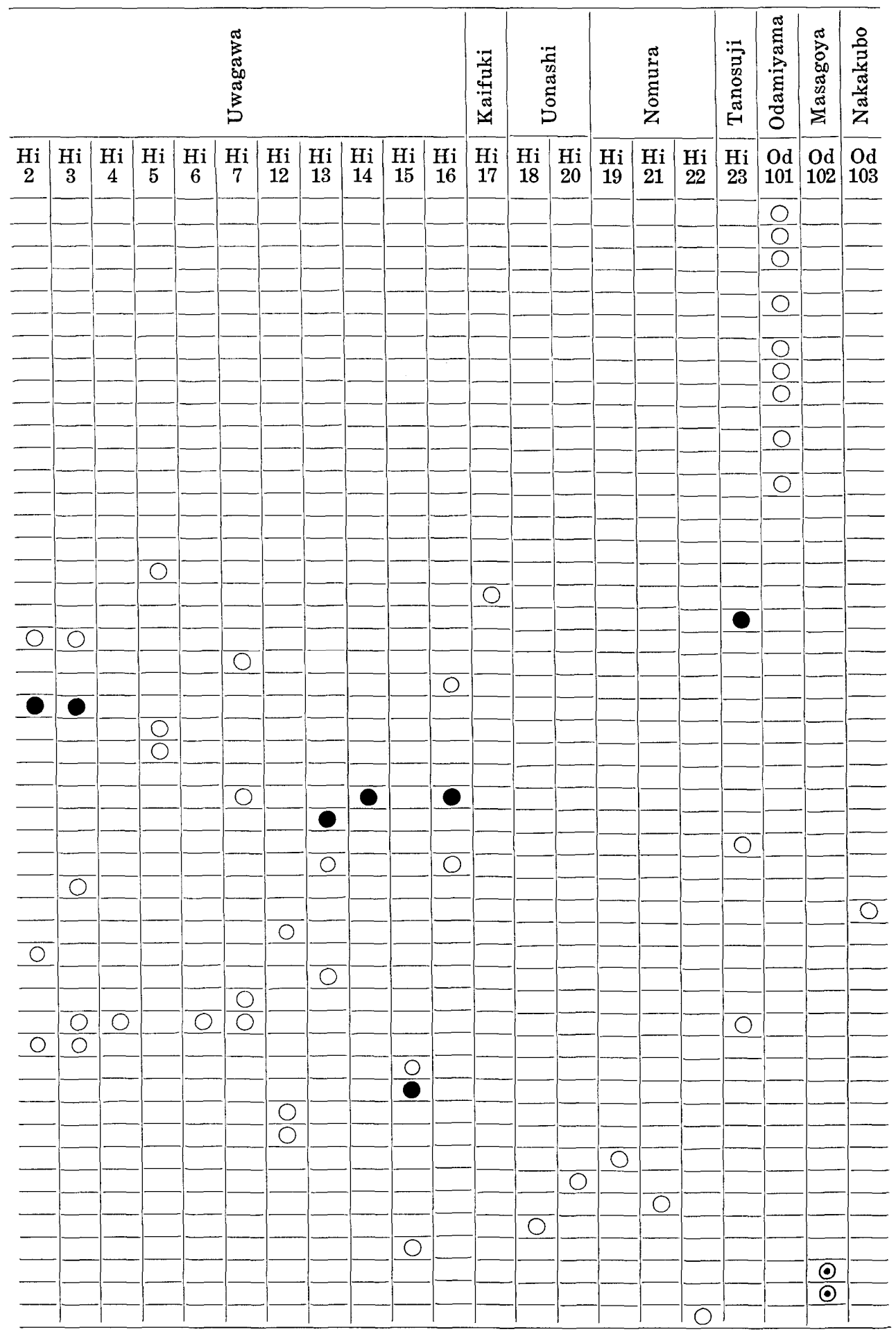


Remarks.-The present specimens are identical with the types of Yabeina katoi (OzAWA). They are also similler to Y. globosa (OzAWA) but are different from the latter in thinner primary transverse septula and axial septula, especially of the inner volutions. Y. katoi has been known to occur often associated with $Y$. globosa as in the present case. The two species cannot be distinguished in their shell-shape and size. They were separated originally in the difference in the thickness of septula and septa, but so far as the specimens at hands are concerned, the intermediate forms are present. Regarding the distinction between the two species further study is necessary on the basis of more numerous specimens from various localities.

Occurrence.-Abundant at loc. Od 102 in the Masagoya Formation. Associated species are shown in Table 3.

\author{
Order Rugosa Milne-Edwards and Haime, 1850 \\ Family Aulophyllidae DyBowski, 1873 \\ Genus Clisiophyllum DANA, 1846 \\ Clisiophyllum subramosum KANMERA \\ Pl. 54, Fig. 10
}

1961. Clisiophyllum subramosum KANMERA, Mem. Fac. Sci. Kyushu Univ., Ser. D, Vol.10, No. 2, p. 211-214, pl. 14, figs. 1-12; pl. 15, fig.11; text-fig. 3.

Material.-One transverse section, reg. no. GE 186 and two longitudinal sections, reg. no. GE 187 and 188 at my disposal.

Description.-Corallum shape unknown. Theca thin. There are two orders of septa, 29 major septa alternating with minor ones of the same number. Major septa thick, reaching almost the axial area. Minor septa three-fourths or less the length of the major ones. All septa dilated in the central part, becoming gradually thin towards both ends.

Dissepimentarium occupies about one-third the radius of corallite. Dissepiments are arranged concentrically in the young stages, but anguloconcentrically or irregularly in the mature stage.

Tabularium occupies more than one-third the radius of corallite composed of numerous incomplete vesicular tabulae. The axial area, occupying about onethird the diameter of corallite, is composed of a median plate, numerous, small vesicular axial tabellae, and many axial lamellae. Axial tabelae are arranged concentrically on both sides of the median plate.

Remarks.-The present species is identical with Clisiophyllum subramosum KANMERA, from the Yayamadake Limestone of Kyushu, Japan.

Occurrence.-Rare at loc. Hi 8 in the Oyabu Formation. Associated fusulinaceans are shown in Table 3.

\title{
Faunal analysis and Correlation
}

The Palaeozoic strata of the present area are intensely folded, faulted, locally overturned, and more or less metamorphosed. Fossils are found only in 
limestone, but they are often strongly deformed or recrystallized. Therefore some of the obtained fusuline fossils have remained specifically unidentified as listed in Table 3.

Under these circumstances the accurate zonation cannot be done, but some of the unidentified species can be referred to certain species-group based on their characteristic features, and some others are allied to certain known species. Therefore the assemblages of these species, together with fairly well preserved, identified species, permit us to correlate them with the known fusuline assemblages of the already established stratigraphic sequences of other areas. Anyhow, the fusuline species described in this paper are biostratigraphically summarized into at least five species-assemblages which can be regarded as approximately referable to the following Zones.

(1) Zone of Fusulinella-Fusulina

(2) Zone of Triticites

(3) Zone of Pseudoschwagerina

(4) Zone of Neoschwagerina

(5) Zone of Yabeina

\section{(1) Zone of Fusulinella-Fusulina}

There are two species-assemblages of the Zone of Fusulinella-Fusulina in the Oyabu Formation. One which occurs from the lower horizon is represented by Fusulinella n. sp. (?) aff. F. hirokoae SUYARI, Beedeina lanceolata (LEE et CHEN), and $B$. cf. mayiensis (SHENG). The first species is smaller than typical $F$. hirokoae which was originally described from the $B$. higoensis zone of the Daigo Formation in eastern Shikoku and is considered to be the ancestor of $F$. hirokoae. B. lanceolata is characteristic of the B. schellwieni zone of the Penchi Series in North China. It is associated with $B$. mayiensis there. This assemblage indicates that the lower part of the Oyabu Formation includes the B. schellwieni zone, the lower part of the Upper Moscovian (Fusulinella-Fusulina Zone).

The other assemblage consists of Staffella sp. ex. gr. S. pseudospheroidae DoUTKEVITCH and Fusulinella sp. It is associated with Clisiophyllum subramosum KANMERA. Staffella pseudospheroidae occurs, according to RAUSER-CHERNOUSSOVA (1936), from the Myachikovo horizon of the Uppermost Moscovian of the Ural Mountains. In Japan it was found in association with Fusulinella sp. from the beds about $40 \mathrm{~m}$ below the Beedeina higoensis zone in the Yayamadake Limestone. Clisiophyllum subramosum occurred from the uppermost part of the B. higoensis zone. It is concluded that the strata characterized by the assemblage is ascribed to the upper part of the Fusulinella-Fusulina Zone, probably the Beedeina higoensis zone.

(2) Zone of Triticites

Only one species of Triticites was found from the middle part of the Kaifuki Formation. It closely resembles the types of Triticites yayamadakensis KANMERA which characterized the T. yayamadakensis zone in the Yayamadake Limestone and some other areas of southern Japan.

Although the material is insufficient for the precise correlation, it is highly 
probable that the middle part of the Kaifuki Formation is referable to the $T$. yayamadakensis zone, the upper part of the Triticites Zone.

(3) Zone of Pseudoschwagerina

The fusuline fossils of the lower part of the Uwagawa Formation and the middle part of the Saitaro Formation in the Hijikawa area and the Tanosuji Formation comprise a species of Pseudoschwagerina, Paraschwagerina, and Pseudofusulina. The diagnostic species are Pseudoschwagerina minatoi KanMERA, Paraschwagerina plicata (LEE), Pseudofusulina regularis (SCHELLWIEN), P. cf. fusiformis (Schellwien), P. cf. vulgaris (Schellwien), P. cf. kumasoana KANMERA and Schwagerina cf. cervicalis (LEE). These species of Pseudofusulina and Schwagerina have been known to occur, in association with species of Pseudoschwagerina and/or Paraschwagerina, in the Zone of Pseudoschwagerina in the Yayamadake Limestone, the Akiyoshi Limestone, the Sakamotozawa Limestone and the Maping Limestone of North China. Unidentified species of Pseudofusulina and Schwagerina are also of the Lower Permian type in shell-structures.

The species-assemblages at the localities where the above mentioned species occur are not always similar to one another, but as a whole they are regarded as belonging to the $P$. minatoi zone, the upper part of the Pseudoschwagerina Zone, or the Pseudofusulina Zone in Japan.

A small lenticular limestone at loc. Hi 5 of the lower part of the Uwagawa Formation contains Quasifusulina sp. and two small undetermined species of Schwagerina. Quasifusulina has so far been known to occur only in the Upper Carboniferous Triticites Zone and the lower part of the Lower Permian Pseudoschwagerina Zone. The association of it with species of Schwagerina indicates that the limestone under consideration is lower than the above mentioned Pseudoschwagerina minatoi zone and belongs to the $P$. morikawai zone, the lower part of the Pseudoschwagerina Zone.

(4) Zone of Neoschwagerina

At about $200 \mathrm{~m}$ above the limestone of the Pseudoschwagerina minatoi zone of the Uwagawa Formation there occurs two small lenticular bodies of limestone. One of them contains Cancellina cf. nipponica OzaWA, Parafusulina kaerimizensis OzAwA and Monodiexodina? sp., and the other Misellina sp., Verbeekina sp. and Pseudofusulina sp. On account of the complicated geologic structure and the difference in assemblage it is not certain whether two limestone lenses are definitely of the same stratigraphic level or not, but the contained species suggest that they are not much separated in geologic age.

Cancellina nipponica is a characteristic element of the Neoschwagerina simplex zone of the Akasaka Limestone in central Japan and that of the Kozaki Formation of south Kyushu and certain other formations of southwestern Japan. Parafusulina kaerimizensis forms a definite zone just above the Misellina claudiae zone in the Akiyoshi Limestone, western Japan, and is one of the characteristic species of the Neoschwagerina simplex zone of the Kozaki Formation. Verbeekina sp. is similar to $V$. verbeeki OzAWA which is another diagnostic species of $N$. simplex zone of the Akasaka Limestone. The obtained species are insufficient and not well oriented, but the verbeekinid species under consideration are clearly 
distinguished from those of two other higher zones of the Neoschwagerina Zone.

To sum up, the two bodies of limestone in question are referable to the Neoschwagerina simplex zone, the lowest part of Neoschwagerina Zone.

Above this zone there is a thick sequence of the upper part of the Uwagawa Formation which is composed dominantly of slate with intercalated chert at several horizons and sandstone and basaltic pyroclastics at some others. No fossils have been obtained from this sequence, but it is mostly referred to the remaining part of the Neoschwagerina Zone.

(5) Zone of Yabeina

The uppermost part of the Nomura Formation and the lowest part of the Masagoya Formation are referred to this Zone, because Yabeina globosa (OzAWA) and Y. katoi (OzAWA) are obtained from the latter and Y. cf. globosa, Pseudodoliolina sp., Neoschwagerina margaritae (DEPRAT) from the former.

Yabeina globosa and Y. katoi are diagnostic and wide spread species of the $Y$. globosa zone in Japan and Neoschwagerina margaritae is not uncommonly associated with them. The stratigraphical relationship between the Nomura Formation and the Uwagawa Formation cannot be determined, because they are separated from each other by faulting, but the lower part of the former may overlap in age with the upper part of the latter.

On this occasion some remarks should be given with respects to the age of the detrital limestone (calclithite) in the upper part of the Odamiyama Formation. The limestone contains Millerella sp., Eostaffella kanmerai Igo, Pseudostaffella cf. kanumai Igo, Fusiella cf. hayashii Igo, Fusulinella itoi Ozawa, $F$. cf. hanzawai IGo, $F$. cf. pseudobocki LEE et CHEN, $F$. sp. and Fusulina sp. These species indicate that this assemblage is a mixed one secondarily derived from beds of various ages, that is, from the Millerella, Profusulinella, and FusulinellaFusulina Zones. The specimens of these species occur as isolated fragments. Therefore the detrital limestone is undoubtedly of higher stratigraphic level than the Fusulinella-Fusulina Zone, although its exact age cannot be determined.

The contained limestone debris are mostly of granule to coarse-grained sand size, well rounded, well sorted, and are considered to have been derived from fairly distant places. The contained fusuline species are mostly characteristic and widespread elements of the above mentioned Zones of the Inner Zone of southwest Japan, such as the Akiyoshi, Taishaku, Aetsu, Ichinotani and Ohmi Limestone. In those limestones it has been confirmed that there is a remarkable stratigraphical break below the base of the Pseudoschwagerina Zone and that the larger part of the Triticites and the Fusulinella-Fusulina Zones and a part of the Profusulinella Zone were eroded or not developed. In the Outer Zone of southwest Japan a local disconformity has been known between the uppermost part of the Triticites Zone and the base of the Pseudoschwagerina Zone, as in Yayamadake Limestone, but there is no evidence of such a remarkable erosion as to attain to the Fusulinella-Fusulina Zone or lower horizons. These facts suggest that the limestone debris under consideration may have been derived from the Inner Zone and the limestone bed may be referable to the Upper Carboniferous or the Lowest Permian. 


\section{Geologic structure}

General remarks.-The Palaeozoic rocks of the present area show a considerably complicated structure with numerous faults and folds of various dimensions. They are also intensely sheared, contorted and fractured and their primary stratification planes have been almost completely obliterated. The argillaceous rocks have been converted at least to slate (not platy but irregularly shredded or crumpled) and even to phyllite in the northern tract. The sandstones are also strongly contorted and fractured to such a degree that original bed-form structures are destroyed into disconnected blocky bodies which lie in stands of slate with irregularly bent, slipped and slicken-sided boundary planes. To cite an instance a 5 meter thick sandstone body is terminated within $10 \mathrm{~m}$ in length. The bedded cherts are often so remarkably overfolded that they abruptly change their apparent thickness within a short distance.

Owing to such intense deformation, it is difficult to ascertain the detailed geologic structure of minor order. The broad outlines of the structure, however, can be secured from actual tracing of a key bed or a key member of a formation and integrating various observations of minor structures, fossil evidence and so forth.

The Palaeozoic strata of the studied area are divisible into three tracts as mentioned below which exhibit dissimilar geologic structures from one another. It is interesting that these tracts are composed of rocks of different lithology, respectively. The geologic profiles along the representative sections in these tracts are shown in Fig. 8.

\section{A. Odamiyama area}

The northern half of the area is widely occupied by a thick series of slate of the Kume Formation in the north and thick beds of greenstones of the Saitaro Formation in the south. These formations form a large open anticline and a syncline with moderately inclined wings and the axes gently plunging to the east.

In the southern half the Odamiyama Formation, Masagoya Formation, and Nakakubo Formation are distributed in three belts from north to south. The Odamiyama Formation of heterogeneous lithologic assemblage, consisting of thin beds of chert, greenstones, slate, dolomite and limestone, forms inverted isoclinal folds in the central part and is thrust up on the Masagoya Formation on the south side with an inclination of about 40 degrees. The thrust, named the Hirakawa thrust, is represented by a crush zone of $20 \mathrm{~m}$ or more with black gouge. It is probably extended to the Nanokawa thrust (KIMURA and HoRIKosHI, 1959) of the Nanokawa area, about $200 \mathrm{~km}$ east from the present area. The Masagoya Formation is underlain by the Nakakubo Formation, although the structure of the latter in the south is not yet clarified.

Some comments should be given here regarding the structural relationship between the Sambagawa metamorphic belt and the Palaeozoic strata of the Chichibu belt in the present area. The boundary between the two belts has been drawn in the direction of ENE-WSW through the central part of the Kume For- 
1
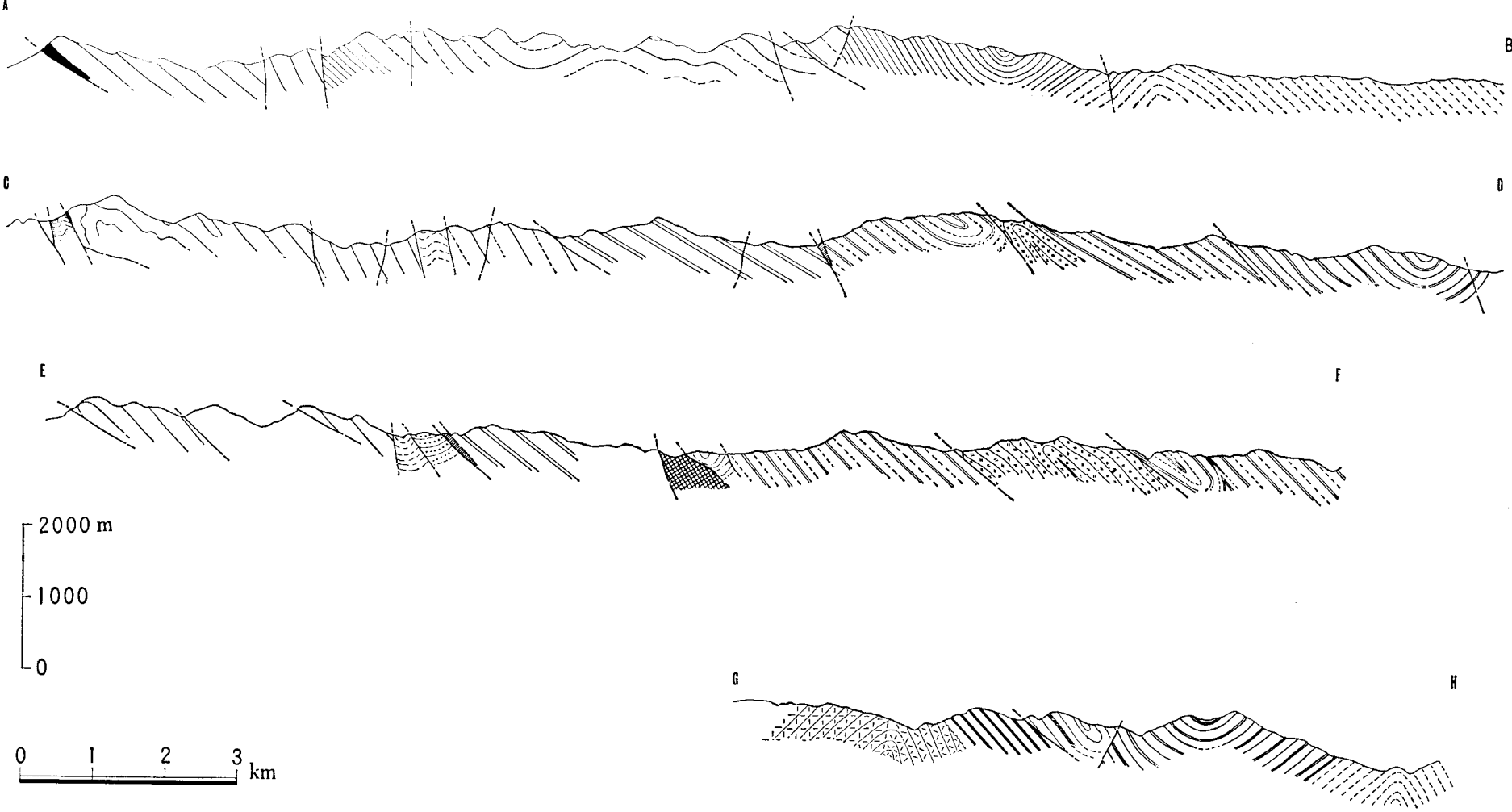

Fig. 8. Geological profiles of the studied area.

A-B, C-D, E-F : Hijikawa and Oozu-Nomura area (see Fig. 3); G-H: Odamiyama area (see?Fig. 2). 
mation. Neither fault nor thrust is actually detected there, but the Kume Formation forms a symmetrical anticline with an axis gently plunging to the east, and the greenstone of the overlying Saitaro Formation is so traceable as to be connected with the Mikabu green rocks to the northeast and further to the north to a thick green schist of the southern marginal belt of the Sambagawa metamorphic belt.

\section{B. Hijikawa area}

Although the thick greenstones of the Saitaro Formation are exposed in the northern marginal belt, the central main part of this area is occupied by a thick series which consists of the Uwagawa Formation of predominant slate, with a subordinate amount of thin chert beds. The Saitaro Formation forms a syncline structure and the Uwagawa Formation constitutes a major inverted anticlinorium, called the Kanogawa anticlinorium, with several minor isoclinal folds dipping to the north. In the axial part of the anticlinorium there occurs the Upper Carboniferous Oyabu Formation, consisting of slate and sandstone with basalt, basaltic tuff and chert. The axis of the anticlinorium gently plunges to the west. On the south side of the wide belt of the Uwagawa Formation which constitutes the southern wing of the Kanogawa anticliorium, there is a narrow belt of the Upper Carboniferous and Lower Permian consisting mainly of black slate. The formation forms a homoclinal structure dipping mainly to the south and is limited on the south by the Kurosegawa tectonic zone along which are squeezed out masses of another kind of metamorphic rocks, granite and the Silurian Formation.

The southwestern marginal part of this area is occupied by the Nomura Formation. The northern boundary of the Nomura Formation is limited by the Kurosegawa tectonic zone near Kurosegawa, but westward or northwestward extension of the formation is demarcated only by a fault which obliquely cuts the Kaifuki and the Uwagawa Formation along which small isolated masses of Triassic dolomite (the Uonashi Formation) are structurally inserted at Kakinoki and Sugiyama.

The Nomura Formation forms an overturned asymmetrical anticline and extends with the NW trend to Nakama. It is composed mostly of black slate.

The southern and southwestern limit of the Nomura Formation is the major thrust, call the Uonashi thrust, that forms the boundary between the Hijikawa and the Oozu-Nomura areas. The Uonashi thrust was first noticed in the Uonashi area by IKEBE, 1936. It extends eastward for more than $12 \mathrm{~km}$, along which the Lower Triassic Uonashi Formation is distributed discontinuously. Its western extension has not so far been confirmed. The present study has clarified that it is strongly curved from Nomura to Oozu in the NW direction. It is inclined to the northeast with an angle of about 35 degrees. Along the thrust the lenses of limestone of the Nomura Formation and those of dolomite of the Uonashi Formation are discontinuously distributed.

To sum up, the Hijikawa area is characterized by repeated isoclinal synclines and anticlines, which constitute a major synclinorium and an anticlinorium. The southwestern boundary of the area is limited by the Uonashi thrust. 


\section{Oozu-Nomura area}

The main part of this area is occupied by the Tanosuji Formation which consists of alternating thick beds of chert and sandstone. The strata form gently undulating structure with the axes slightly plunging to the east.

The Itagatani Formation, a part of the Sambosan Group, occupies the southern part of the area and is monoclinally inclined towards the north in a larger part but locally forms a fairly closed anticline structure near the southern margin. The southern limit of the formation is a major tectonic line, called the Butsuzo tectonic line, which forms the boundary between the Chichibu and the Shimanto belts.

In the central part of the area the Upper Jurassic Imaidani Formation is narrowly intercalated between the Tanosuji and the Itagatani Formations with a fault relation.

The Butsuzo tectonic line of the present area is subdivided into three faults of different ages, as has already been discussed (KAshima, 1968). Namely the (1) Hokezu thrust, (2) Takagawa fault and (3) Kuroiji fault. The Hokezu thrust (SUzUKI, 1935), which was formed by the earliest movement, is a low angle thrust. The Takagawa and the Kuroiji faults are high angle faults formed in later ages.

\section{Metamorphic zones}

The Palaeozoic rocks of the Chichibu belt are more or less metamorphosed. On the basis of metamorphic mineral assemblage of the greenstones of the basic igneous rock origin, two progressive metamorphic zones are distinguished in the studied area. They are conventionally called in this paper Zone I and Zone II.

Zone I is the lower grade prehnite-pumpellyite zone, in which quartz, albite, prehnite, pumpellyite, chlorite, calcite, epidote, stilpnomelane, lucoxene, hematite, sericite and montmorillonite are found. Zone II is a higher grade, glaucophane schist zone, in which quartz, albite, chlorite, actinolite, calcite, stilpnomelane, glaucophane, riebeckite, pumpellyite, epidote, leucoxene, hematite and sericite are found.

Zone I is characterized by the presense of pumpellyite and the absence of actinolite and glaucophane. Prehnite is rare. Zone II is distinguished by the appearance of actinolite and glaucophane. In other words, the amphibole isograd demarcates the boundary of Zone I and Zone II.

The general distribution of the metamorphic zones is shown in Fig. 9. In regard to the metamorphic grade, the rocks in the eastern Odamiyama area are wholly ascribed to Zone I, whereas those in the western Hijikawa and OozuNomura areas are divided into Zone I and Zone II with the amphibole isograd in between. The amphibole isograd runs in the northeast-southwest direction from Michiyashiki to Kitaura. The rocks of the northwestern side of the amphibole isograd belong to Zone II and those of the southeastern side to Zone I. Thus the metamorphism grade progressively increases from southeast to northwest in the present area. 


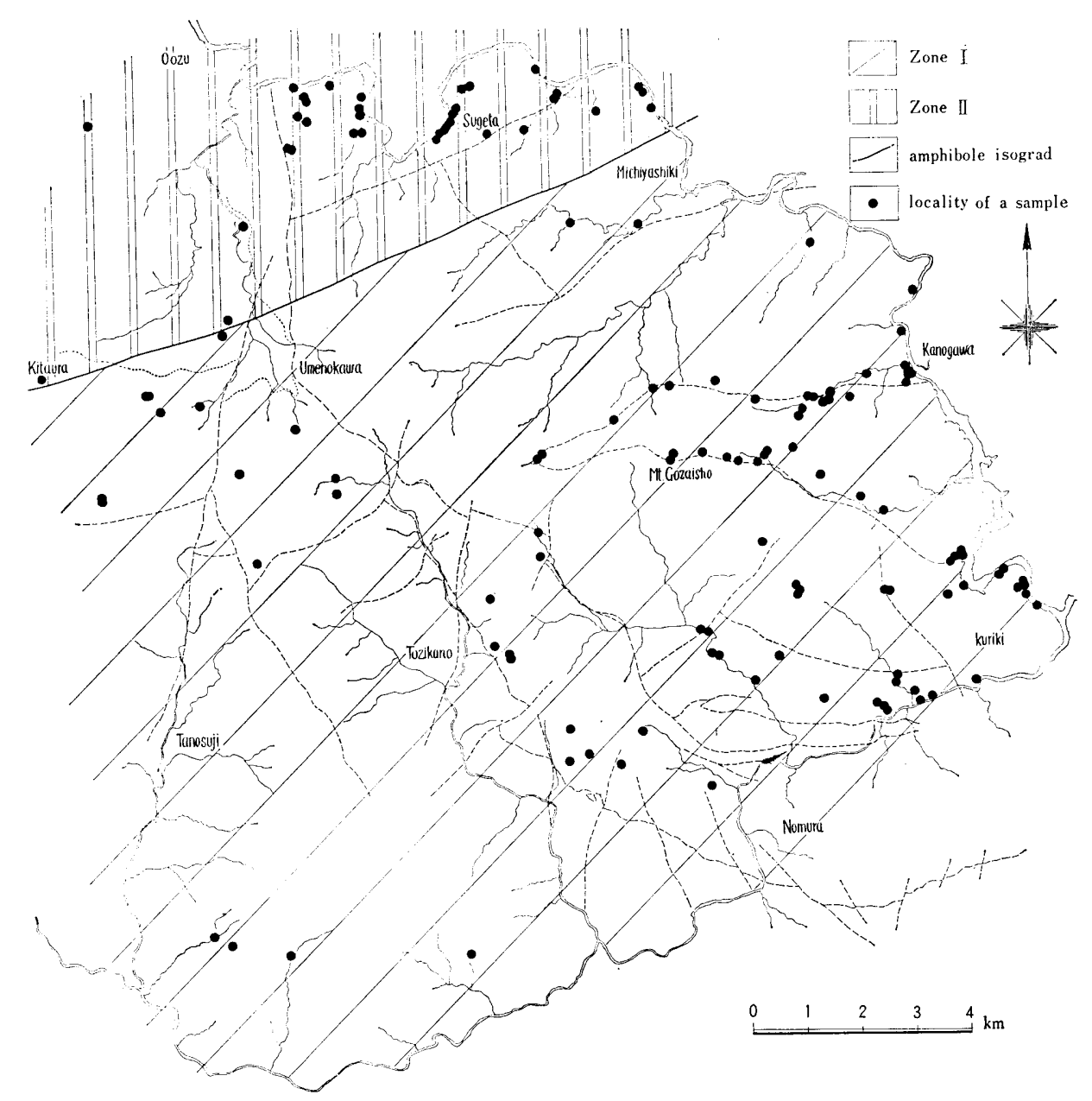

Fig. 9. Metamorphic zones in the Hijikawa and Oozu-Nomura area.

Zone I covers a large part of the Chichibu belt in this area, although its southern limit has not yet been determined. Zone II occupies a portion of the Chichibu belt and also the major part of southern Sambagawa belt.

It should be emphasized that the amphibole isograd runs in NE-SW trend, cutting obliquely the stratigraphical boundaries and structural forms in the present area. Broadly speaking, the trend is parallel to the general structure trends of the Palaeozoic and Mesozoic in Shikoku.

\section{Discussion}

I. Relation between the Sambagawa southern marginal belt and the Chichibu belt

Regarding the stratigraphical and structural relationships between the non or less metamorphosed Palaeozoic sequences and the distinctly metamorphosed 
Table 4. Comparative representation of the stability of some metamorphic minerals in the Sambagawa metamorphic belt and the Sangun metamorphic belt.

(1) Kii Peninsula (Sekt, Y., Oba, T., Mori, R. and KerigaWA, S., 1964)

\begin{tabular}{|l|l|l|l|}
\hline \multirow{2}{*}{$\begin{array}{l}\text { Prehnite } \\
\text { Pumpellyite }\end{array}$} & I & II & III \\
\cline { 2 - 3 } Actinolite & & & \\
Stilpnomelane & & & \\
Epidote & & & \\
\cline { 2 - 4 } & & & \\
\cline { 2 - 4 } & & & \\
\hline
\end{tabular}

(2) Bessi-Ino District (BanNo, S., 1964)

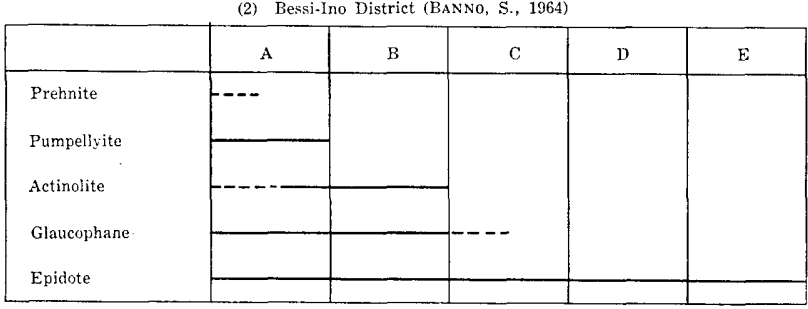

(3) Western Shikoku (Hashiмoto, M. and Kashima, N., 1969)

\begin{tabular}{|l|c|c|}
\hline & I & II \\
\hline Pumpellyite & & \\
\cline { 2 - 3 } Actinolite & & \\
Glaucophane. & & \\
Stilpnomelane & & \\
Epidote: & & \\
\hline
\end{tabular}

(4) Katsuyma District (Hashimoto, M., 1968a)

\begin{tabular}{|l|c|c|}
\hline & \multicolumn{1}{|c|}{ I } & II \\
\hline \multirow{2}{*}{ Pumpellyite } & & \\
\cline { 2 - 3 } Actinoiite & & \\
\cline { 2 - 3 } Glaucophane. & & \\
\cline { 2 - 3 } Stilpnomejane & & \\
\cline { 2 - 3 } Epidote & & \\
\hline
\end{tabular}

(5) Asahi-cho Area (Hashimoto, M., 1968b)

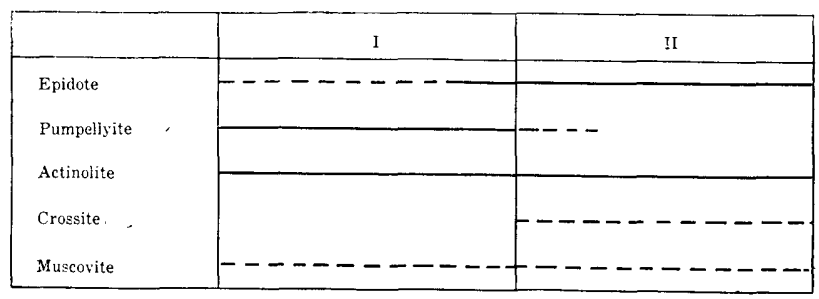


rocks in the Japanese Islands our knowledge is still incomplete. The boundary between the Palaeozoic rocks of the Chichibu belt and the Sambagawa metamorphic rocks has long been regarded as being represented by a prominent fault zone called the Mikabu tectonic line often with intrusives of the so-called Mikabu green rocks (KоJiмA, 1950).

The fault relation between the two belts has been really confirmed by later works in central Shikoku (Kamiyakawa tectonic line by IsHII et al., 1957), western Kii peninsula (Aritagawa tectonic line by HADA, 1967) and eastern Kii (Takihara thrust by KIMURA, 1954).

However, SUZUKI (1964a; 1965) has clarified that in the Agawa and Ikegawa areas, central Shikoku, the rocks of the southern marginal zone of the Sambagawa belt and those of the northern part of the Chichibu belt respectively constitute the northern and the southern wings of an anticline and that along the axial part of it a fault is locally found.

In the present area the Kume Formation, together with the overlying Saitaro Formation and the equivalent Futaiwa Formation, similarly forms an anticlinal structure. The northern wing of the Kume Formation belongs to the Sambagawa southern marginal belt and the southern wing of it to the Chichibu belt. Neither fault nor thrust is found between the two belts.

The thick basic volcanic rocks of the Saitaro Formation can be continuously traced into the Mikabu green rocks of the boundary zone and further to the thick green schist member of the southern marginal zone of the Sambagawa belt. Thus the Mikabu green rocks of the present area are of the same stratigraphic level as the volcanic series of the lower part of the Saitaro Formation. Both of them are composed mainly of lavas, sills and pyroclastic rocks of ophiolitic rock assemblage, and show a close resemblance in lithology and occurrence to the Mikabu green rocks of central and eastern Shikoku. We have to recall here again that the lower part of the Saitaro Formation is of Lower Permian in age on fossil evidence, as has already been mentioned in page 396 .

Some remarks should be also given here on the stratigraphic relation of the green schist member under consideration to the reference section of the Sambagawa proper in central Shikoku, locally called the Yoshinogawa Group. According to KoJima (1950) and KoJima et al. (1956) the group displays the following sequence:

$$
\text { Yoshinogawa Group } \begin{cases}\text { upper subgroup } & \begin{array}{l}
\text { Ojoin Formation } \\
\text { middle subgroup }
\end{array} \\
\text { lower subgroup } \begin{array}{l}
\text { Minawa Formation } \\
\text { Koboke Formation }
\end{array} & \begin{array}{l}
\text { Kawaguch Formation } \\
\text { Oboke Formation }
\end{array}\end{cases}
$$

KoJima (1956) also established the three-fold division of the metamorphic rocks of the southern marginal zone and referred the middle unit containing thick beds of green schist to the lower main part of the Minawa Formation mentioned above.

To sum up, the green schist member under consideration is correlated with the Minawa Formation of the Sambagawa proper area and both of them can be referred to Lower Permian in age. 


\section{Relation between the stratigraphical divisions and metamorphic zones}

The Mikabu tectonic line generally demarcates the boundary between the Sambagawa belt on the north and the Chichibu belt on the south. In the present area the boundary is not a thrust but an axial plane of an anticlinorium. In other words the southern part of the Sambagawa belt and the Chichibu belt form an anticlinal structure, with an axis running from east to west. Furthermore the basic volcanic rocks in the Chichibu belt were so metamorphosed that they contain metamorphic minerals of the Sambagawa type. In other words the Chichibu belt was at least partly subject to the Sambagawa metamorphism.

The present area is divided into two metamorphic zones, Zone I and Zone II. The grade of metamorphism progressively increases from the southeast to the northwest in the Chichibu belt and furthermore extends to the southern part of the Sambagawa belt.

It should be stressed that the amphibole isograd which demarcates the boundary of the metamorphic zones cuts obliquely the Uonashi thrust and other structural forms and also stratigraphic boundaries.

In many areas other than the present area the boundaries between different metamorphic zones are distributed generally in harmony with the structural forms or stratigraphic boundaries, as exemplified by the situation in the BessiIno area in central Shikoku (BANNo, 1964), Kotu-Bizan area in eastern Shikoku (IWASAKI, 1967), Aritagawa area in western Kii peninsula (HADA, 1967) and Katsuyama and Asahi-cho areas in Okayama Prefecture (HAsнiмoto, 1968a and 1968b).

On the other hand, SEKI, et al. (1964) recognized that a boundary between the two metamorphic zones obliquely cuts the tectonic belts in central Kii peninsula.

In western Shikoku the Upper Carboniferous and Permian strata in the Hijikawa area, which are strongly folded and partly overturned, are displaced from the northeast to the southwest and are thrust up to the strata of the OozuNomura area. The Jurassic Imaidani Formation and the Lower Neocomian (Lower Cretaceous) Ryoseki Series are involved in this thrusting, as has already been noticed by BANDo (1964).

Consequently, the crustal movements, which gave rise to the folds and thrusts of the present area, must have continued at least to the early Cretaceous. In connection with the crustal movements, the metamorphism under consideration must have taken place. As the Cretaceous strata are not well distributed in the present area the upper limit of the time range of the crustal movements cannot be precisely determined. The problem should be solved on other lines of evidence.

A geochronological study of the K-Ar age on biotite from the Sambagawa metamorphic rocks in the Bessi-Ino area, central Shikoku, has given 81-94 million years (BANNo et al., 1961; MILler et al., 1961). On this ground BANNo concluded that the Sambagawa metamorphic belt was formed in a late Mesozoic age. The observations in western Shikoku in the present study are consistent with this conclusion of BANNO. 


\section{Summary of Results}

(1) The Palaeozoic strata of western Shikoku, about $5300 \mathrm{~m}$ in total thickness, are of eugeosynclinal lithologic assemblage, consisting primarily of sandstone, mudstone, chert and altered basic volcanic rocks (greenstones) with a small amount of limestone.

(2) On the grounds of the distribution of the Palaeozoic rocks the studied area is divisible into three tracts, the Odamiyama, the Hijikawa and the OozuNomura.

The Odamiyama area consists mainly of thick series of slate and thick beds of greenstone, which altogether form a large open anticline and a syncline with moderately inclined wings and the axes gently plunging to the east.

The Hijikawa area consists predominantly of slate, with some sandstone, chert and greenstones, and is characterized by repeated isoclinal synclines and anticlines, which constitute a major synclinorium and an anticlinorium.

The main part of the Oozu-Nomura area consists mainly of alternating thick beds of chert and sandstone, which form gently undulating structures with the axes slightly plunging to the east.

The Uonashi thrust, that forms the boundary between the Hijikawa and the Oozu-Nomura areas, is strongly curved in the NW direction. The area on its southwestern side is occupied by the major Kanogawa anticlinorium.

(3) The stratigraphy of Upper Carboniferous and Permian formations in this area is summarized in Fig. 5, in which the conclusion of correlation is also shown.

(4) The obtained fusulinacean fossils are listed in Table 3. Palaeontological descriptions are given for selected species which are important for the age determination.

(5) The sandstones of the Upper Palaeozoic formations in this area are dominantly composed of feldspathic wacke and subordinately of feldspathic arenite (Table 1). The rock fragments as the sand grains are chiefly of volcanic origin, and subordinately derived from sedimentary, granitic and metamorphic rocks. The relative proportion of their contents is shown in Table 2. It is noteworthy that volcanic-rock fragments are characterized by basaltic to andestic rocks and most plagioclase grains have a composition of andesine to labradorite. Granitic rock fragments are found in the Itagatani, Tanosuji, Uwagawa, Saitaro, Futaiwa, Kume and Oyabu Formations, and metamorphic ones in the Itagatani, Tanosuji, Uwagawa and Oyabu Formations.

From all the lines of petrographic evidence, it is concluded that the sandy clastics of the Palaeozoic strata in the studied area were chiefly derived from volcanic rocks and subordinately from sedimentary, granitic and metamorphic ones.

(6) Greenstones of the basic volcanic rocks, which constitute the lower part of the Saitaro Formation, are of ophiolitic assemblage. These greenstones are continuously extended to the so-called Mikabu green rocks. Therefore the Mikabu green rocks are approximately of the same stratigraphic level as the 
Saitaro Formation. As a result of the biostratigraphic correlation, the age of these green rocks are concluded as Lower Permian.

(7) In this area the Mikabu tectonic line is not represented by a thrust. The boundary between the Sambagawa southern marginal belt and the Chichibu belt is an axial plane of an anticlinorium. The Kume Formation forms asymmetrical anticline, the north wing belongs to the Sambagawa southern marginal belt and the south wing to the Chichibu belt. The overlying Saitaro Formation is connected with the Mikabu green rocks. The Saitaro Formation and the Mikabu green rocks are, in turn, correlated with the main part of the Minawa Formation of the Sambagawa Group.

(8) From the distribution of metamorphic minerals in basic rocks, the present Chichibu belt can be divided into two progressive metamorphic zones, namely Zone I of a lower prehnite-pumpellyite zone and Zone II of a higher grade glaucophane schist zone. The amphibole isograd demarcates the boundary between the Zone I and Zone II.

(9) The boundary of the two metamorphic zones, the amphibole isograd, runs in NE-SW trend, cutting obliquely the Uonashi thrust and other structural forms and also stratigraphic boundaries in the present area.

(10) The crustal movements in this area, which involved Upper Carboniferous, Permian, Triassic, Jurassic and early Cretaceous (Lower Neocomian) into deformation, must have continued at least to the early Cretaceous. In connection with the crustal movements the Sambagawa type metamorphism under consideration must have taken place.

\section{References}

BANDo, Yuji (1961): Biostratigraphical correlation of the Lower and Middle Triassic formation by ammonoid fossils from Japan (in Japanese). Jour. Geol. Soc. Japan, 67, (789), 323-334.

(1964a): Study on the Triassic ammonoids and stratigraphy of JapanPart 1: Lower Triassic, with a note on the boundary between the Permian and Triassic Systems in Japan (in Japanese). Ibid., 70, (825), 301-314, pl. 1.

$(1964 b)$ : The Triassic stratigraphy and ammonite fauna of Japan. Sci. Rep. Tohoku Univ., [2], 36, (1), 1-137, pls. 1-15.

Banno, Shohei and Miller, J. A. (1961): New data on the dating of the Ryoke and Sambagawa metamorphic rocks (in Japanese). Kagaku, 31, 144.

(1964): Petrology of Sambagawa crystalline schists in the Bessi-Ino district. Jour. Fac. Sci., Univ. Tokyo, [2], 15, (3), 203-319.

Chen, Shu (1934): Fusulinidae of South China, Part 1. Palaeontologia Sinica, [B], 4, (2), 1-185, pls. 1-26.

(1956): Fusulinidae of South China, Part II. Ibid., [N. S. B], 6, 17-71, pls. 1-14.

Coombs, D. S. (1960): Lower grade mineral facies in New Zealand. Rept. Internat. Geol. Congr., 21 Session Norden, pt. 13, 339-351.

Folk, Robert L. (1959): Practical petrographic classification of limestone. Bull. Amer. Assoc. Petr. Geol., 43, (1), 1-38.

(1962): Spectral subdivision of limestone types. Amer. Assoc. Petr. Geol., 1, 62-84.

FUJII, Koji (1962): Petrography of the Upper Palaeozoic sandstone from the Yatsushiro area, Kyushu. Fujil, Koji, Kanmera, Kametoshi and Matsumoto, Ta- 
tsuro (1962): Notes on the Chichibu geosyncline. Mem. Fac. Sci., Kyushu Univ., [D], 12, (3), 179-218.

Ginkel, A. C. (1965): Carboniferous Fusulinids from the Cantabrian Mountains (Spain). Leidse Geologische Mededellingen, (34-12-5), 1-225, pls. 1-53.

HADA, Shigeki (1967): Geology of the middle-Aritagawa district, Wakayama Prefecture, with special reference to the relationship between the Chichibu belt and the Sambagawa belt. Bull. Osaka Mus. Nat. History, (20), 39-60.

Hashimoto, Mitsuo (1964): A review of the petrology of the Sangun metamorphic rocks, Japan (in Japanese). Bull. Nat. Sci. Mus. Tokyo, 9, (3), 323-337.

(1966a): On the prehnite-pumpellyite metagreywacke facies (in Japanese). Jour. Geol. Soc. Japan, 72, (5), 253-265.

(1966b) : Metamorphism of the Palaeozoic volcanic Rocks in the Inner Zone of southwest Japan (in Japanese). Bull. Volcanol. Soc. Japan, (2), 11, 93-98.

(1968a): Glaucophanic metamorphism of the Katsuyama district, Okayama Prefecture, Japan. Jour. Fac. Sci. Univ. Tokyo, [2], 17, (1), 99-162.

(1968b): Sangun metamorphic terrain of the Asahi-cho area, Okayama Prefecture (in Japanese). Jour. Geol. Soc. Japan, 74, (8), 433-437.

Hirata, Motome (1958): Some important new facts from the Chichibu zone of the central part of Shikoku (in Japanese). Earth Sci. (Chikyukagaku), (36), 22-24.

(1961) :The geology of the mountain districts of Oonogahara and Torigatayama (in Japanese). Chigaku Kenkyu, 12, (1), 35-41.

Hirayama, Ken and Kambe, Nobukazu (1956): Geological map of Yawatahama and Iyo-takayama sheets (scale 1:50000). Geol. Surv. Japan, 1-33.

Honjo, Susumu (1959): Neoschwagerinids from the Akasaka Limestone (a palaeontological study of the Akasaka Limestone, 1st report). Jour. Fac. Sci. Hokkaido Univ., [4], 10, (1), 111-161, pls. 1-12.

нuлгмото, Haruyoshi (1936): Stratigraphical and palaeontological studies of the Titibu System of the Kwanto-mountainland Part 2. Palaeontology. Sci. Rep. Tokyo Bunrika Daigaku, [C], (2), 29-125, pls. 1-24.

IchiKawa, Koichiro, Ishi, Kenichi, Nakagawa, Chuzo, Suyari, Kazumi and YamaSHITA, Noboru (1954): Meso-Palaeozoic rocks in the environs of Kurosegawa tectonic zone, Ehime Prefecture. Jour. Geol. Soc. Japan, 60, (706), 310-311.

, - - -, and - (1956): Die Kurosegawa-zone (Untersuchungen über das Chichibu-terrain in Shikoku-III) (in Japanese). Jour. Geol. Soc. Japan, 62, (725), 82-103.

Igo, Hisayoshi (1957): Fusulinids of the Fukuji, southeastern part of the Hida massif, central Japan. Sci. Rep. Tokyo Kyoiku Daigaku, 5, (47), 153-246, pls. 1-15.

IkeBe, Nobuo (1936): On the Uonashi thrust (in Japanese). Chikyu (The Globe), 25 , 399-408, fig. 1 .

ImaI, Hideki (1960): Basic rocks in the Okuki mine (in Japanese). Jour. Soc. Min. Geol. Japan, 10, (39), 31-32.

Iмото, Nobuhiro and Shimonishi, Shigeyoshi (1965): On 'Schalstain' in the western district of Shuzan. The study of 'schalstain' in the Tanba district (Part 1). (in Japanese). Bull. Kyoto Gakugei Univ., [B], (27), 59-63.

INmAN, D. L. (1952): Measures for describing the size distribution of sediments. Jour. Sedim. Petro., 22, (3), 125-145.

IsHII, Kenichi (1956): Itadorigawa Group in western Shikoku. On some problem concerning the Middle Pennsylvanian of Japan (Studies on the Chichibu terrain in Shikoku-V). (in Japanese). Jour. Geol. Soc. Japan, 62, (724), 20-29. , Ichikawa, Koichiro, Katto, Jiro, Yoshida, Hironao and KoJima, George (1957): Geology of the Chichibu terrain along the highway from Kamiyakawa to Ino, Shikoku (in Japanese). Jour. Geol. Soc. Japan, 63, (743), 449-454.

(1958a) : Fusulinids from the Middle Upper Carboniferous Itadorigawa Group in western Shikoku, Japan. Part I. Genus Fusulina. Jour. Inst. Polytech. Osaka 
City Univ., [G], 4, 1-28, pls. 1-5.

(1958b): On the phylogeny, morphology and distribution of Fusulina, Beedeina and allied fusulinid Genera. Ibid., 4, 29-70, pls. 1-4.

(1961) : Fusulinids from the Middle Upper Carboniferous Itadorigawa Group in western Shikoku, Japan. Part III. Stratigraphy and concluding remarks. Ibid., 5, 31-52.

and Yamagiwa, Nobuo (1961): A new species of the genus Clisiophyllum from the Upper Carboniferous of Ehime Prefecture, southern Japan. Trans. Pro. Palaeont. Soc. Japan, [N. S.], (44), 153-156.

(1962) : Fusulinids from the Middle Upper Carboniferous Itadorigawa Group in western Shikoku, Japan. Part II. Genus Fusulinella and other Fusulinids. Jour. Geosciences, Osaka City Univ., 6, (1) , 1-58.

IsHIZAKI, Kunihiro (1962): Stratigraphical and palaeontological studies of the Onogahara and its neighbouring area, Kochi and Ehime Prefecture, southwest Japan. Sci. Rep., Tohoku Univ., [2], 34, (2), 95-185, pls. 7-12.

Iто, Shosuke (1954): Structural features of the ore deposit of the Okuki mine (in Japanese). Jour. Soc. Min. Geol. Japan, 4, (13), 158-163.

IWASAKI, Masao (1967): Metamorphic rocks of the Kotu-Bizan area, eastern Shikoku. Jour. Fac. Sci. Univ. Tokyo, [2], 15, (1), 1-90.

and BANDo, Harue (1966): Petrological studies on the 'Mikabu-type basic metamorphic rocks' I. Basic metamorphic rocks in the Sanagouchi area, Tokushima Prefecture (in Japanese). Jour. Gakugei, Tokushima Univ., 16, 15-24.

Kanmera, Kametoshi (1952): The Upper Carboniferous and the Lower Permian of the Hikawa valley, Kumamoto Prefecture, Kyushu, Japan. (in Japanese). Jour. Geol. Soc. Japan, 58, (676), 17-32.

(1954): The Fusulinids from the Yayamadake Limestone of the Hikawa valley, Kumamoto Prefecture, Kyushu, Japan. Part I. Fusulinids of the Upper Middle Carboniferous. Japan. Jour. Geol. Geogr., 25, (1-2), 117-144, pls. 12-14. (1955): Fusulinids from the Yayamadake Limestone of the Hikawa valley, Kumamoto Prefecture, Kyushu, Japan. Part II. Fusulinids of the Upper Carboniferous. Japan. Jour. Geol. Geogr., 27, (3-4), 177-192, pls. 11-12.

(1957): Revised classification of Cancellina and Neoschwagerina, and evolution of Sumatrinae and Neoschwagerinae. Mem. Fac. Sci., Kyushu Univ., [D], 6, (1), 47-64, pls. 19-20.

(1958): Fusulinids from the Yayamadake Limestone of the Hikawa valley, Kumamoto Prefecture, Kyushu, Japan. Part III. Fusulinids of the Lower Permian. Mem. Fac. Sci., Kyushu Univ., [D], 6, (3), 153-215, pls. 24-35.

(1961a): Middle Permian Kozaki Formation (in Japanese). Sci. Rep. Fac. Sci., Kyushu Univ., 5, (4), 196-215.

(1961b): Upper Carboniferous corals from the Yayamadake Limestone, Kyushu. Mem. Fac. Sci., Kyushu Univ., [D], 10, (2), 207-232, pls. 14-18.

(1963) : Fusulines of Middle Permian Kozaki Formation of southern Kyushu. Ibid., 14, (2), 79-141, pls. 11-19.

- and Furukawa, Hiroyasu (1964): Stratigraphy of the Upper Permian and Triassic Konosé Group in Kyushu (in Japanese). Sci. Rep. Fac. Sci., Kyushu Univ., 6, (3), 237-258.

and Mikami, Takahiko (1965a): Succession and sedimentary features of the Lower Permian Sakamotozawa Formation. Mem. Fac. Sci., Kyushu Univ., [D], 16, (3), 265-274.

and - $(1965 \mathrm{~b})$ : Fusuline zonation of the Lower Permian Sakamotozawa Series. Ibid., 275-320, pls. 44-53.

(1968): On some sedimentary rocks associated with geosynclinal volcanic rocks (in Japanese). A systematic study of geosynclinal sediments (1). Mem. Geol. Soc. Japan, 1, 23-32.

(1969): Upper Palaeozoic stratigraphy of the northern Chichibu belt in eastern Shikoku (in Japanese). Sci. Rep. Fac. Sci., Kyushu Univ., 9, (1), 
175-185.

Kanuma, Mosabro (1957): Stratigraphical and Palaeontological studies of the southern part of the Hida plateau and the northeastern part of the Mino mountainland. Part II. Palaeontology, (3). Bull. Tokyo Gakugei Univ., 10, 59-83, pls. 4-9.

KASHima, Naruhiko (1960): The new localities of fossils in the Oonogahara district, Ehime Prefecture (in Japanese). Jour. Geol. Soc. Japan, 66, (772), 52.

- and MiYahisa, Michitoshi (1965): Geology of the so-called Sambosan zone of western Shikoku, with some considerations on the stage of fault-movements of the Butsuzo tectonic line (in Japanese). Mem. Ehime Univ., [2], D, 5, (2), 39-59.

(1967): The arrangement of strata in the Chichibu terrain in western Shikoku, Japan (in Japanese). A study of the Chichibu terrain in western Shikoku V (in Japanese). Jour. Geol. Soc. Japan, 73, (6), 281-289.

and MiYahisa, Michitoshi (1968): Geology in the southern district of Odacho, Ehime Prefecture, Japan. A study of the Chichibu terrain in western Shikoku VI (in Japanese). Oda-cho no Shizen to Jinmon, 105-110.

(1968): The Butsuzo tectonic line in western Shikoku, Japan. A study of the Chichibu terrain in western Shikoku VII (in Japanese). Jour. Geol. Soc. Japan, 74, (9), 459-471.

Katto, Jiro and KaWASAwA, Keizo (1958): The Palaeozoic System of the northern environs of Ino, Kochi Prefecture (in Japanese). Res. Rep. Kochi Univ., 7, (19), 1-8, pl. 1.

(1963): The geology of the Kanogawa dam site, and the landslides along the river Hijikawa in Ehime Prefecture (in Japanese). Ibid., 12, (4), 1-39.

KAWACHI, Yosuke (1968): Large-scale overturned structure in the Sambagawa metamorphic zone in central Shikoku, Japan. Jour. Geol. Soc. Japan, 74, (12), $607-616$.

KAWASAWA, Keizo (1965): The geology of the environs of Kawabegawa (Hiji-river) (in Japanese). Suzaki High School Kenkyu Ronshi, (1), 7-13.

Kimura, Toshio (1954): The discovery of the low angle thrust, along the Mikabu line in eastern Kii Peninsula, western Japan: Description of areal geology and sedimentary rocks. Jour. Earth Sci., Nagoya Univ., 2, 173-190.

(1957): The geologic structure and the sedimentary facies of the Chichibu Group in the eastern Kii Peninsula; a contribution to the geotectonic study of southwest Japan. Sci. Pap. Coll. Gener. Edu. Univ., Tokyo, 7, (2), 243-272.

and HoRIKoshI, Ei (1959): On the geologic structure of the Chichibu terrain in western central Shikoku. Ibid., 9, (2), 329-342.

(1961): The lateral faulting and geologic structure of the eastern part of southwest Japan. Jap. Jour. Geol. Geogr., 32, (2), 317-330.

(1968): Some folded structures and their distribution in Japan. Ibid., 39, (1) , 1-26.

Kobayashi, Manabu (1957): Palaeontological study of the Ibukiyama Limestone, Shiga Prefecture, central Japan. Sci. Rep. Tokyo Kyoiku Daigaku, [C], (48), 247-311, pls. 1-10.

KoвAYASHI, Teiichi (1941): The Sakawa orogenic cycle and its bearing on the Japanese Islands. Jour. Fac. Sci. Imp. Univ. Tokyo, [2], 7, 219-578.

KoJima, George (1950): On the so-called Mikabu System in the outer zone of southwestern Japan (in Japanese). Jour. Geol. Soc. Japan, 56, (657), 339-344.

, Hide, Kei and Yoshino, Gensei (1956): The stratigraphical position of Kieslager in the Sambagawa crystalline schist zone in Shikoku (in Japanese). Jour. Geol. Soc. Japan, 62, (724), 30-45.

, Yoshida, Hironao, Katto, Jiro, Ichikawa, Koichiro and Ishir, Kenichi (1956) : Geology of the Sambagawa crystalline schist zone along the highway from Saijo to Kamiyakawa, Shikoku (in Japanese). Ibid., 62, (729), 316-326.

Krumbein, W. C. (1941): Measurement and geological significance of shape and 
roundness of sedimentary particles. Jour. Sed. Pet., 11, (2), 64-72, pl. 1.

Larsen, G. and Chilingae, G. V. (Editor) (1967) : Diagenesis in sediments. Developments in sedimentology (8), 551 p., Elsevier Published Company.

LeE, J. S. (1927) : Fusulinidae of North China. Palaeontologia Sinica, [B], 4, (1), $1-174$, pls. $1-24$.

- Chen, S. and CHu, S. (1930): The Huanglung Limestone and its Fauna. Mem. Nat. Res. Inst. Geol., 9, 85-143, pls. 2-15.

Matsumoto, Tatsuro and Kanmera, Kametoshi (1949): Contribution to the tectonic history in the outer zone of southwest Japan. Mem. Fac. Sci., Kyushu Univ., [D], 3, (2), 77-90.

(1964): On the age of the geosynclinical volcanism (in Japanese). Sci. Rep. Fac. Sci., Kyushu Univ., 7, 149-159.

and KANMERA, Kametoshi (1964): Explanatory text of the geological map on Japan (scale 1:50000) Hinagu, Kagoshima (49). Geol. Surv. Japan, 1-147.

(1967): Fundamental problems in the Circum-Pacific orogenesis. Tectonophysics, 4, (4-6), 595-613.

Miller, John, Shido, Fumiko, Banno, Shohei and Uyeda, Seiya (1961): New data on the age of orogeny and metamorphism of Japan. Japan. Jour. Geol. Geogr., 32, $145-151$.

Minato, Masao (1951): Some Carboniferous corals from southwest Japan. Trans. Proc. Palaeont. Soc. Japan, [N. S.], (1), 1-5.

(1955): Japanese Carboniferous and Permian corals. Jap. Soc. Prom. Sci., Ueno, Tokyo, 1-202, pls. 1-43.

and Nakazawa, Keiji (1957): Two Carboniferous corals from Okayama Prefecture. Trans. Proc. Palaeont. Soc. Japan, [N. S.], (25), 17-20.

, TAKEDA, Hiroyuki and Kato, Makoto (1959a): On the volcanic rocks in the Japanese Palaeozoic, 2nd report: Carboniferous (in Japanese). Jour. Geol. Soc. Japan, 65, (762), 165-170.

, - and $(1959 \mathrm{~b}):$ On the volcanic rocks in the Japanese Palaeozoic, 3rd report: Permian. Ibid., 65, (763), 222-226.

and Honjo, Susumu (1959): The axial septula of some Japanese Neoschwagerininae with special remarks of the phylogeny of the subfamily Neoschwagerininae DUNBAR and CoNDra, 1928. Jour. Fac. Sci. Hokkaido Univ., [4], 10, (2), 305-336, pls. 1-6.

and KAто, Makoto (1965): Waagenophyllidae. Ibid., 12, (3-4), 1-241, pls. 120.

Miyahisa, Michitoshi, Kashima, Naruhiko, Hrraoka, Takuro, Shioda, Ichiro, Aizawa, Koji, Hino, Teruo and Higaki, Kiyoshi (1964): Dolomite deposits of the Odamiyama area, Ehime Prefecture (in Japanese). Kokunai Tekko Genryo Chosa, 3, 375-380.

- and (1967): Geological studies on the dolomite deposits of Chichibu terrain, western Shikoku, Japan (in Japanese). Jour. Soc. Min. Geol. Japan, 17, (84), 214-227.

MiYASHIRo, Akiho and SEki, Yotaro (1958): Mineral assemblages and subfacies of the glaucophane schist facies. Japan. Jour. Geol. Geogr., 29, 199-208.

(1958): On the study of glaucophanic metamorphism. Jour. Geol. Soc. Japan, 64, (750), 146-151.

(1959): Abukuma, Ryoke and Sambagawa metamorphic belts (in Japanese). Ibid., 65, (769), 624-637.

(1967) : Orogeny, regional metamorphism, magmatism in the Japanese Islands. Meddelelser fra Dansk Geologisk Forening, 17, (4), 390-446.

Mizutani, Shinjiro (1957): Permian sandstone in the Mugi area, Gifu Prefecture, Japan. Jour. Earth Sci., Nagoya Univ., 5, (2), 135-151.

(1964): Superficial folding of the Palaeozoic System of central Japan. Ibid., 12, (1), 17-83, pls. 1-5.

Morikawa, Rokuro (1955): Schwagerininae in the vicinity of the Shomaru pass, 
eastern part of Kwanto mountainland, central Japan. Sci. Rep. Saitama Univ., [B], 2, (1), 45-114, pls. 5-15.

(1958): Fusulinids from the Akasaka Limestone (Part 1). Ibid., 3, (1), 93-130, pls. 12-26.

and Isomi, Hiroshi (1961): Studies of Permian fusulinids in the east of lake Biwa, central Japan. Geol. Surv. Japan, Rep. (191), 1-29, pls. 1-21.

and SuzukI, Yukiko (1961): Fusulinids from the Akasaka Limestone (Part 2). Sci. Rep. Saitama Univ., [B], 4, (1), 43-74, pls. 4-22.

Nagai, Kozo and Kashima, Naruhiko (1963): The Upper Jurassic Tanohama Formation in Akehama-cho, Higashiuwa-gun, Ehime Prefecture (in Japanese). Mem. Ehime Univ., [2], D, 4, (4), 145-151.

Nakagawa, Chuzo, SUYari, Kazumi, Ichikawa, Koichiro, IshiI, Kenichi and YamaSHITA, Noboru (1959): Geology of Kurosegawa district, Ehime Prefecture. (Studies on the Chichibu terrain in Shikoku IV) (in Japanese). Jour. Gakugei Tokushima Univ., 9, 33-58.

Nogami, Yasuo (1961): Permische fusuliniden aus dem Atetsu-Plateau sudwestjapans. Teil. 1, Fusulininae und Schwagerininae. Mem. Coll. Sci., Univ. Kyoto, [13], 27, (3), 159-225, pls. 1-11. Teil. 2, Verbeekininae, Neoschwagerininae u. a., Ibid., 28, (2), 159-228 pls. 1-7.

OKADA, Hakuyu (1968a): Classification and nomenclature of sandstone (in Japanese). Jour. Geol. Soc. Japan, 74, (7), 371-384.

(1968b): Notes on classification and nomenclature of sandstone (in Japanese). Ibid., 74, (12), 617-622.

Ozawa, Yoshiaki (1925a): On the classification of fusulinidae. Jour. Coll. Sci., Tokyo Imp. Univ., 45, (4), 1-26, pls. 1-4.

(1925b): Palaeontological and stratigraphical studies on the Permo-Carboniferous limestone of Nagato. Part II, Palaeontology. Ibid., 45, (6), 1-90, pls. 1-14.

(1927): Stratigraphical studies of the fusulina limestone of Akasaka, Province of Mino. Jour. Fac. Sci., Imp. Univ. Tokyo, [2], (3), 121-164, pls. 34-45.

Rauser-Chernoussova, D. Beljaev, D. and Reitlinger, E. (1936): Die ober palaozoischen foraminiferen aus dem Petschora-Lands (Der westabhang der nordUrals): Acad. Sci. U. S. S. R., Trans. Polar Comm., 28, 159-232, pls. 1-6.

SADA, Kimiyoshi (1960): On the Upper Permian fusulinid fauna in the Atetsu limestone plateau, Okayama Prefecture (in Japanese). Jour. Geol. Soc. Japan, 66, (777), 410-425.

(1964): Carboniferous and Lower Permian fusulinines of the Atetsu Limestone in west Japan. Jour. Sci. Hiroshima Univ., [C], 4, (3), 225-269, pls. 2128.

(1965): Carboniferous and Permian stratigraphy of the Atetsu Limestone in west Japan. Ibid., 5, (1), 21-80.

SAKA, Yukiyasu (1967): Geological structure of the Chichibu terrain in the vicinity of Yura-machi, Wakayama Prefecture, southwest Japan. Jour. Earth Sci., Nagoya Univ., 15, (1), 1-34.

Seki, Yotaro, Oba, Tadamichi, Mori, Ryuji and Kuriyagawa, Sakiko (1964): Sambagawa metamorphism in the central part of Kii peninsula. Jour. Japan. Assoc. Min. Petro. Econ. Geol., 52, (3), 73-89.

(1965): Behavior of carbon-dioxide in low-grade regional metamorphism (in Japanese). Ibid., 54, (1), 1-13.

(1966) : Pumpellyite-bearing mineral assemblages and type of metamorphism (in Japanese). Ibid., 55, (3), 104-111.

Sheng, J. C. (1958): Fusulinids from the Penchi Series of the Taitzeho valley, Liaoning. Palaeontologia Sinica, [N. S.], (7), 58-119, pls. 1-16.

(1963) : Permian fusulinids of Kwangsi, Kueinchow and Szechuan. Ibid., 10, 1-119, 129-247, pls. 1-36.

Shimizu, Saburo and Jıмво, Noboru (1933): On the Triassic ammonite from Taho, 
Iyo (in Japanese). Chikyu (The Globe), 19, (1), 10-31.

SUYARI, Kazumi (1961): Geological and palaeontological studies in central and eastern Shikoku, Japan. Part I, Geology. Jour. Gakugei, Tokushima Univ., 11, 11-76.

(1962) : Part II. Palaeontology. Ibid., 12, 1-64, pls. 1-12.

Suzuki, Takashi (1964a): Relation between the Sambagawa and the Chichibu zone in the district of Agawa, Kochi Prefecture. Jour. Geol. Soc. Japan, 70, (825), $339-347$.

(1964b): The Mikabu green rocks in Shikoku (I) The Mikabu green rocks and its geological structure in the district of Osugi, Kochi Prefecture. .Res. Rep. Kochi Univ., 13, [1], (10), 93-102.

(1965): On the Kamiyakawa-Ikegawa tectonic line. Geol. Rep. Hiroshima Univ., (14), 293-306.

(1967): The Mikabu greenrocks in Shikoku. With special reference to distribution and occurrence of agglomeratic rocks (in Japanese). Jour. Geol. Soc. Japan, 73, (4), 207-216.

Suzukr, Tatsuo (1935): Explanatory text of the geologic map of Japan (scale 1:75000), Sheet Unomachi (in Japanese). Geol. Surv. Japan, 1-41.

Tamura, Minoru (1960): A stratigraphic study of the Torinosu Group and its relatives (in Japanese). Mem. Fac. Educ. Kumamoto Univ., 8, Supplement, 1-40.

(1961): The Torinosu Series and fossils therein the geologic history of the Torinosu epoch and Mesozoic reef-limestone in Japan. Japan. Jour. Geol. Geogr., 32, (2), 219-277, pl. 8.

Toriyama, Ryuzo (1944): The fusulinids in the limestone conglomerates of the Sakuradani area in the Province of Awa. Ibid., 19, (1-4), 67-82, pl. 6.

(1958): Geology of Akiyoshi. Part III. Fusulinids of Akiyoshi. Mem. Fac. Sci., Kyushu Univ., [D], 7, 1-264, pls. 1-48.

(1967): The Fusulinacean Zones of Japan. Ibid., 18, (1), 35-260.

Toyoda, Hideyoshi (1953) : On the Geological Structure of Misaki Peninsula, Shikoku (Petrolo-geological Studies on the Crystalline Schists of Western Shikoku, I) (in Japanese). Mem. Ehime Univ., [2], 1, (4), 133-138.

- and Noma, Yasuji (1955): Crystalline Schist System of the Neighbourhood of Yawata-hama City, Shikoku (Petrolo-geological Studies on the Crystalline Schists of Western Shikoku, II) (in Japanese). Ibid., [2], 2, (3), 165-169.

YaBe, Hisakatsu and Sugryama, Toshio (1930-31): Note on a Lower Permian stromatoporoid from Japan. Japan. Jour. Geol. Geogr., 8, 19-21.

and - (1930-31) :: Stromatoporoids and related forms from the Jurassic of Japan. Ibid., 8, 23-28.

and - (1932-33) : : Upper Triassic spongiomorphoid coral from Sampozan, Province of Tosa, Japan. Ibid., 10, 5-9.

and - (1930-35): Jurassic stromatoporoids from Japan. Sci. Rep. Tohoku Imp. Univ., 14, 135-192.

Yemara, Shingo (1925): On the Triassic ammonites from the Nomura basin, Province Iyo. Jour. Geol. Soc. Tokyo, 32, (386), 37-40.

(1928): The Triassic cephalopod and bivalve fauna of Shikoku. Japan. Jour. Geol. Geogr., 5, 135-172, pls. 13-17.

(1929): Geologic and tectonic study of Shikoku. Ibid., 7, 1-42.

Yoshimura, Toyohumi (1952) : Manganese deposits in Japan (in Japanese). Manganese Investigation Association. $567 \mathrm{p}$. 


\section{Appendix}

Alphabetic List of Place-Names, with Japanese Writing

\begin{tabular}{|c|c|c|c|c|c|c|}
\hline Amagiri & 雨 & & 霧 & Nakakubo & 中 & 久 \\
\hline Funabara & 舟 & & 原 & Noda & 野 & \\
\hline Futaiwa & 双 & & 岩 & Nomura & 野 & \\
\hline Gozaisho & 御 & 在 & 所 & Oda & 小 & \\
\hline Hanaga & 歯 & & 長 & Odamiyama & 小 & 田 深 \\
\hline Hijikawa & 肱 & & 川 & Ogura & 小 & \\
\hline Hirakawa & 平 & & 川 & Okegoya & 桶 & 小 \\
\hline Inazumi & 稲 & & 積 & Okushirahige & 奥 & 白 \\
\hline Ino & 稲 & & 生 & Ootani & 大 & \\
\hline Itagatani & 板 & ケ & 谷 & Oozu & 大 & \\
\hline Iwaidani & 祝 & & 谷 & Oyabu & 小 & \\
\hline Kaifuki & 貝 & & 吹 & Saitaro & 才 & 太 \\
\hline Kakinoki & 柿 & の & 木 & Shirahige & 白 & \\
\hline Kamanokawa & 釜 & の & 川 & Shiraishi & 白 & \\
\hline Kamikawa & 上 & & 川 & Shishigoe & 獅 & 子 \\
\hline Kannonsui & 観 & 音 & 水 & Sugeta & 菅 & \\
\hline Kanogawa & 鹿 & 野 & 川 & Sugiyama & 杉 & \\
\hline Kitaura & 北 & & 裏 & Taho & 田 & \\
\hline Kootoshi & 木 & & 落 & Tanisuji & 渓 & \\
\hline Kume & 久 & & 米 & Tanosuji & 田 & 之 \\
\hline Kuriki & 栗 & & 木 & Tochinoki & 橡 & の \\
\hline Kuroiji & 黒 & 井 & 地 & Tojikano & 鳥 & 鹿 \\
\hline Kuroki & 黒 & & 木 & Tosaka & 鳥 & \\
\hline Maruishi & 丸 & & 石 & Uchiba & 内 & \\
\hline Masagoya & 柾 & 小 & 屋 & Umenokawa & 梅 & の \\
\hline Matsuo & 松 & & 尾 & Uonashi & 魚 & \\
\hline Michiyashiki & 道 & 屋 & 敷 & Uwagawa & 宇 & 和 \\
\hline Moriyama & 森 & & 山 & Yanadani & 柳 & \\
\hline Nagatani & 長 & & 谷 & Yatsuko & 八 & \\
\hline Nakadori & 中 & & 通 & Yokono & 横 & \\
\hline Nakama & 中 & & 間 & & & \\
\hline
\end{tabular}


Naruhiko KASHIMA

Stratigraphical Studies of the Chichibu Belt

in Western Shikoku

Plates $54 \sim 60$ 
Plate 54 


\section{Explanation of Plate 54}

Figs. 1-3. Fusulinella n. sp. (?) F. hirokoae SUYARI ...........Page 407 1. Axial section, GE 7 ; 2. diagonal section, GE 9 ; 3. sagittal section, GE 18 from loc. $\mathrm{Hi} 9$. All $\times 20$.

Figs. 4-6. Beedeina lanceolata (LeE et CHEN) ................. Page 408 4, 6. Axial sections, GE 1, GE 2, respectively; 5, sagittal section, GE 3 from loc. Hi 9 . All $\times 20$.

Figs. 7-8. Parafusulina haerimizensis (Ozawa) ............. Page 411 7. Sagittal section, GE 163; 8. axial section, GE 158 from loc. Hi. 15. All $\times 10$.

Fig. 9. Paraschwagerina plicata (LEE) ..................... . . . . . 410 Diagonal section, GE 85 from loc. Hi $7 . \times 10$.

Fig. 10. Clisiophyllum subramosum KANMERA .............. Page 416 Transverse section, GE 186 from loc. Hi 8. $\times 6$.

Fig. 11. Cancellina (Minoella) cf. nipponica OzaWA ............ Page 412 Parallel section, GE 173 from loc. Hi 15 . $\times 10$. 

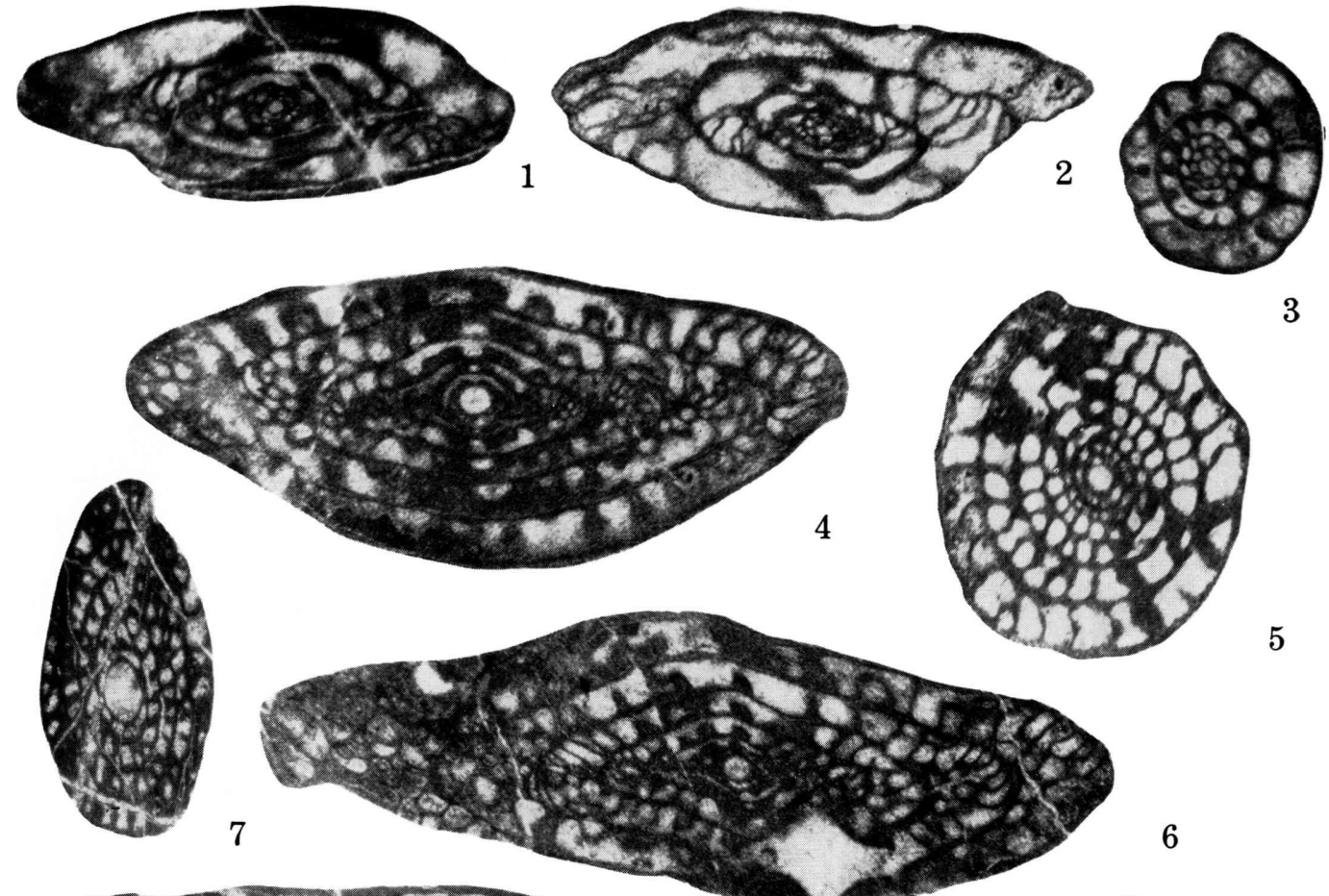

3
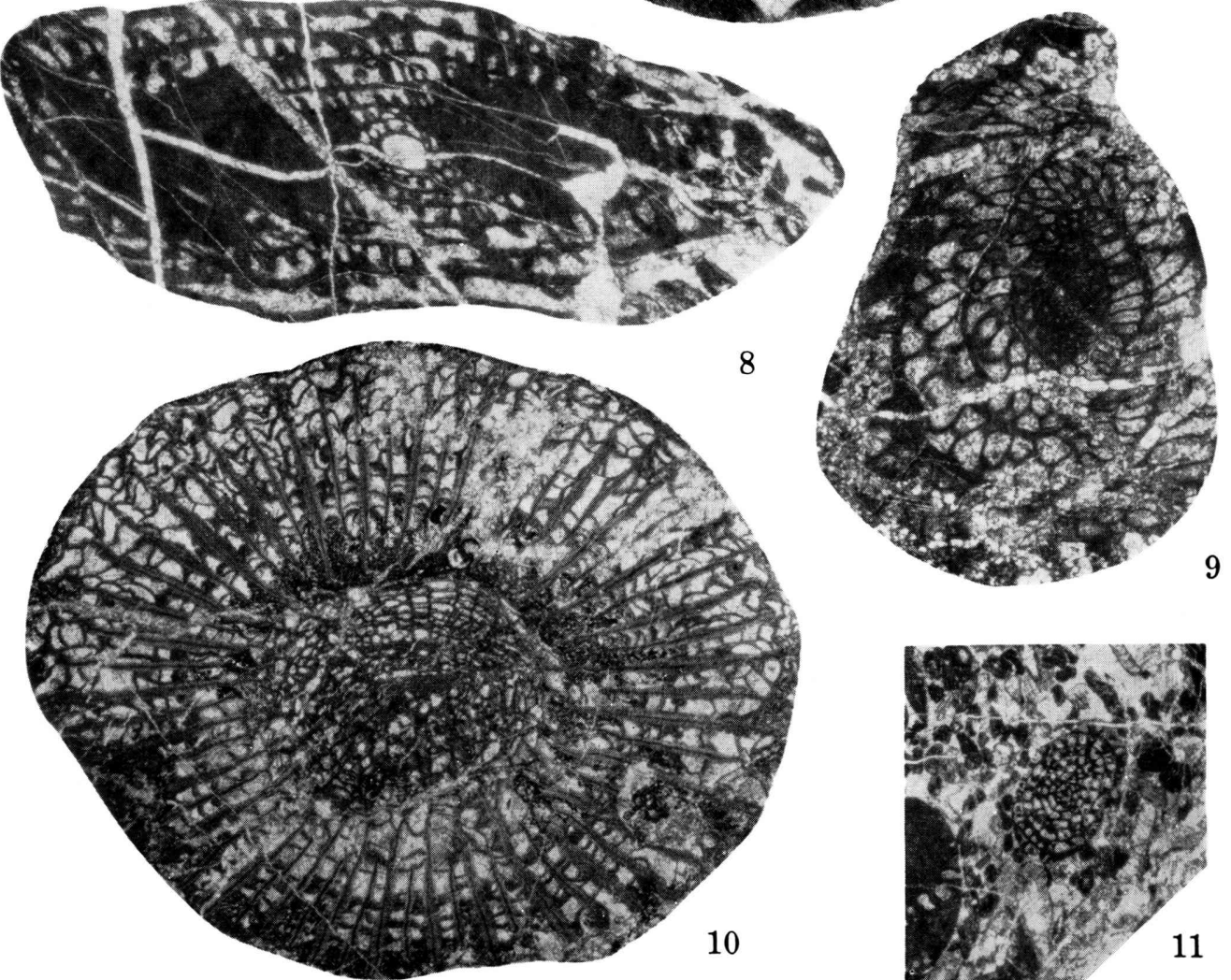

N. Kashima: Stratigraphical studies of the Chichibu belt. 
Plate 55 


\section{Explanation of Plate 55}

Figs. 1, 2. Yabeina globosa (OzAwA) ........................... 412

1. Parallel section, GE 178; 2. sagittal section, GE 181 from loc. Od $102 . \times 10$.

Figs. 3, 4. Yabeina katoi (OzAWA) ............................. 413

3. Axial section, GE 175; 4. sagittal section, GE 177 from loc. Od 102 . $\times 10$.

Figs. 5, 6. Pseudoschwagerina minatoi Kanmera .............. Page 409 5. Sagittal section, GE 77; 6. parallel section, GE 82 from loc. Hi $23 . \times 10$.

Fig. 7-9. Triticites sp. ex gr. T. yayamadakensis KANMERA........Page 409 7, 8. Oblique sections, GE 73, GE 74, respectively; 9. sagittal section, GE 75 from loc. Hi 17. All $\times 20$.

Fig. 10. Schwagerina? sp. or Pseudofusulina? sp. . . . . . . . . Page 410 Oblique section, GE 103 from loc. Hi $1 . \times 10$. 


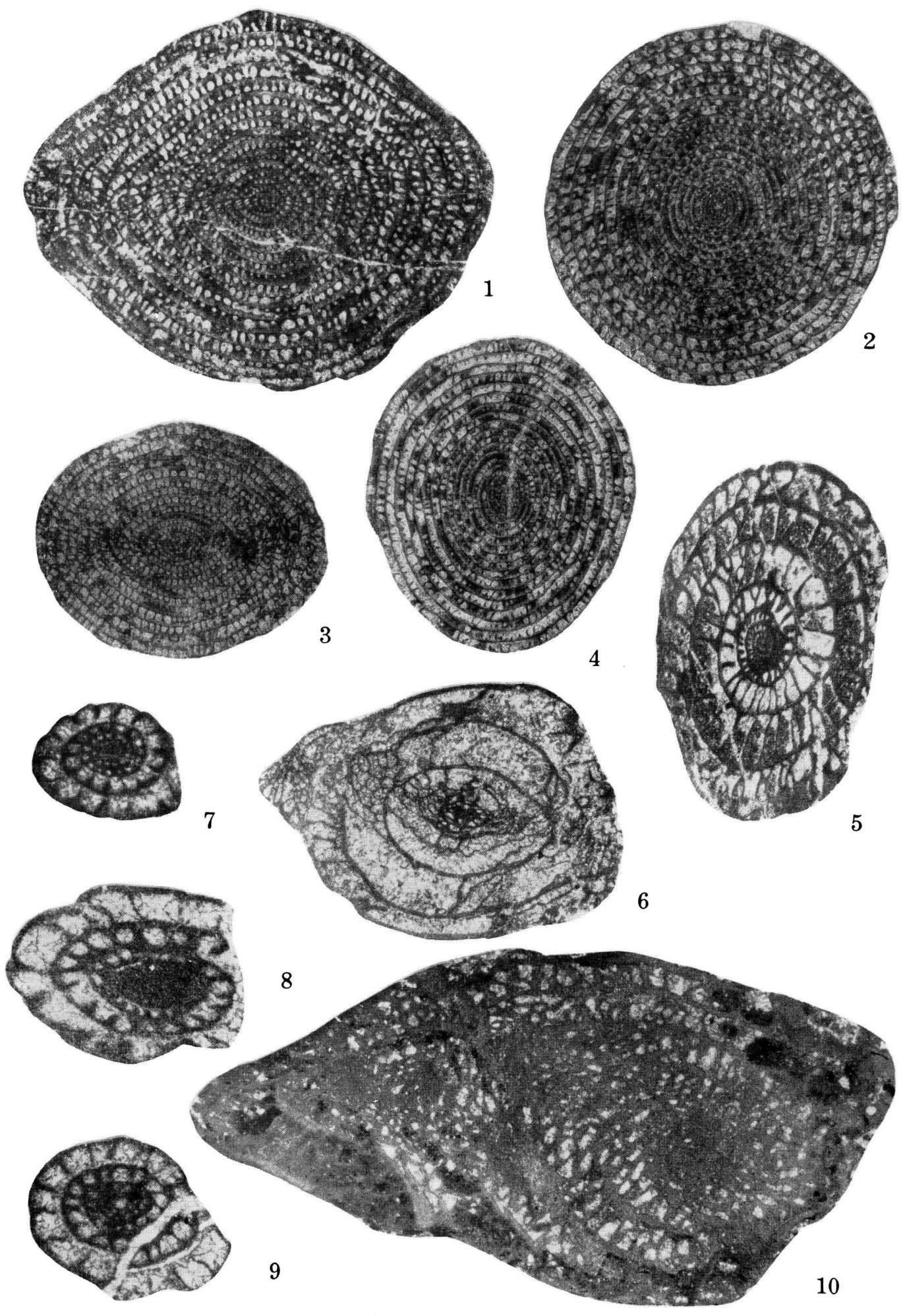

N. Kashima: Stratigraphical studies of the Chichibu belt. 
Plate 56 


\section{Explanation of Plate 56}

(All are of crossed nicols; $\times 10$ )

Fig. 1. Lithic arenite from the Uwagawa Formation (68090205).

Fig. 2. Lithic wacke from the Tanosuji Formation (65041803).

Fig. 3. Feldspathic arenite from the Tanosuji Formation (65041808)

Fig. 4. Feldspathic wacke from the Itagatani Formation (21). 

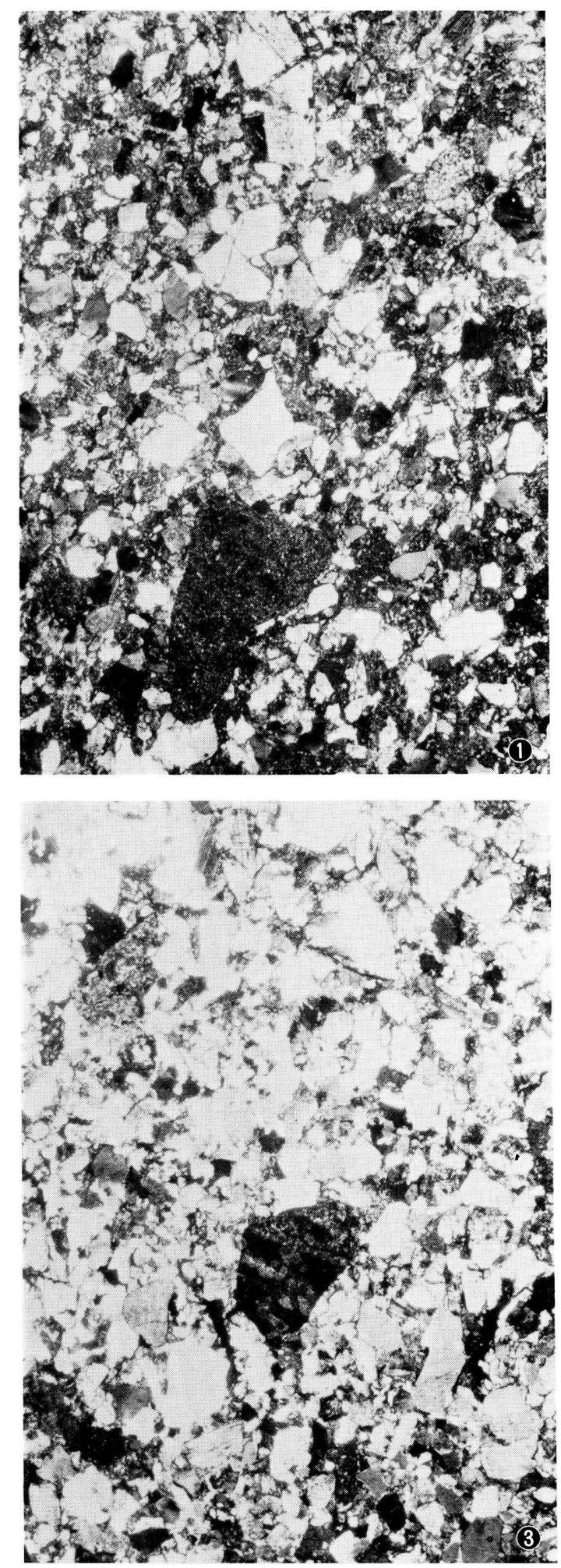

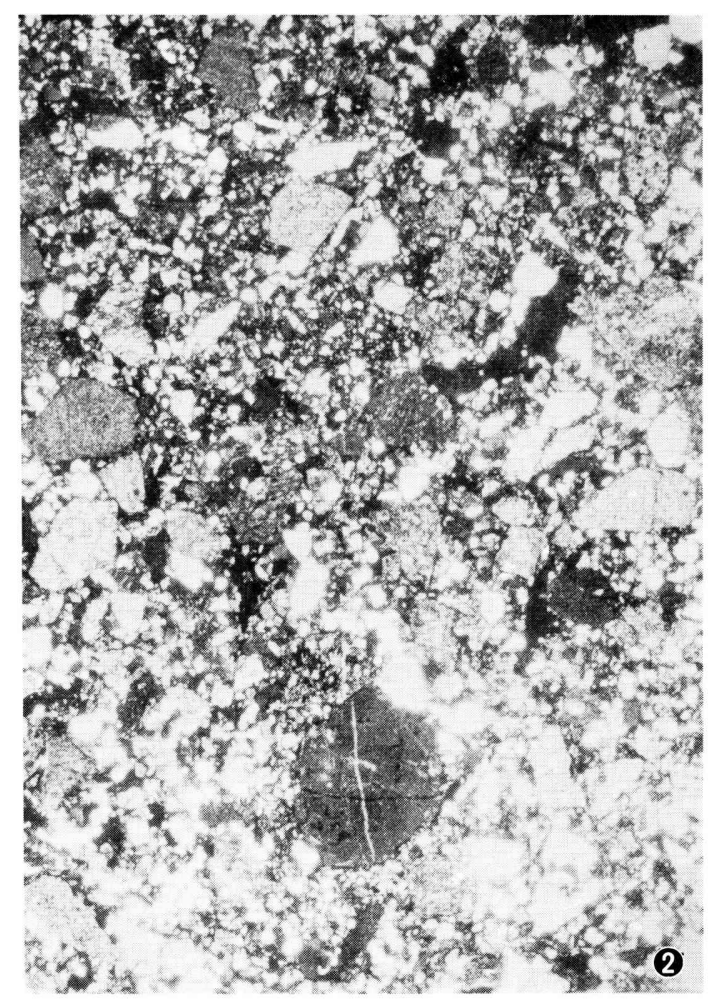

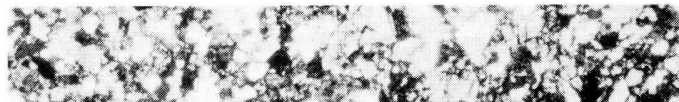

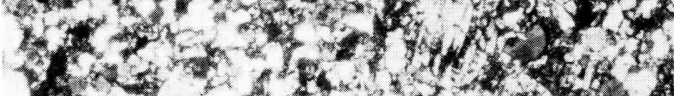

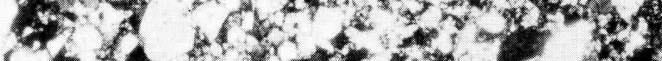

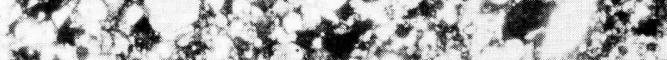

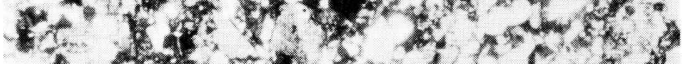

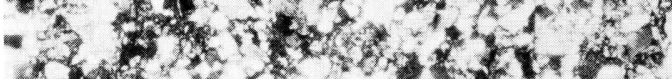

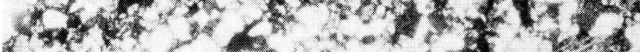

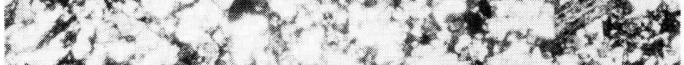

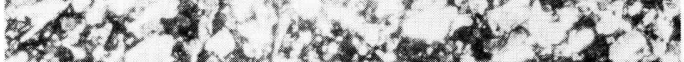

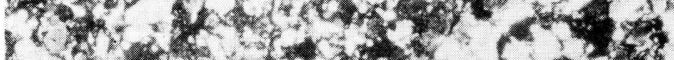

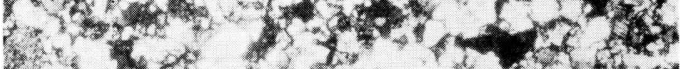

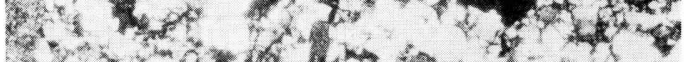

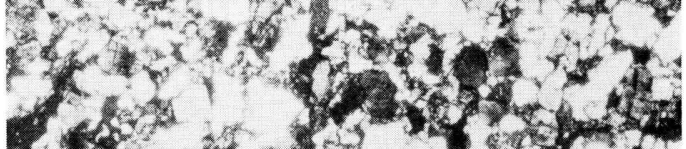
3.5.

N. KASHIma: Stratigraphical studies of the Chichibu belt. 
Plate 57 


\section{Explanation of Plate 57}

(All Figures $\times 10$ )

Fig. 1. Basaltic tuff from the Kume Formation (66072503), ordinary light.

Fig. 2. Basaltic tuff from the Saitaro Formation (66033007), ordinary light.

Fig. 3. Microgabbro from the Uwagawa Formation (66031627), ordinary light.

Fig. 4. Amygdaloidal basalt from the Uwagawa Formation (66041006), crossed nicols. 

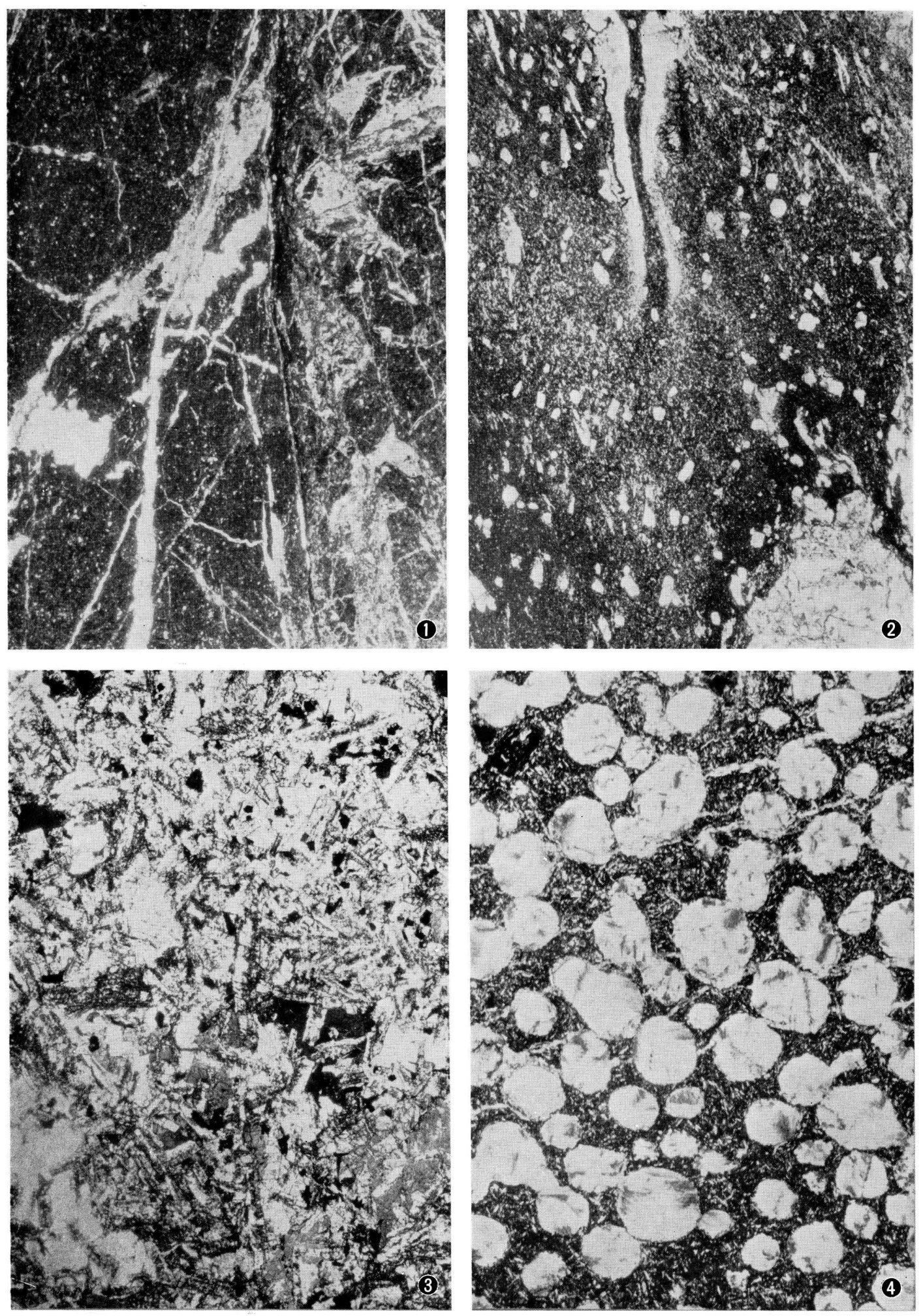

N. Kashima: Stratigraphical studies of the Chichibu belt. 
Plate 58 


\section{Explanation of Plate 58}

(All Figures $\times 10$ )

Fig. 1. Stained basalt from the Oyabu Formation (66041206), ordinary light.

Fig. 2. Olivine basalt from the Kaifuki Formation (66040820), crossed nicols.

Fig. 3. Porphyritic basalt from the Saitaro Formation (65031601), ordinary light.

Fig. 4. Dolerite from the Nakakubo Formation (65032906), crossed nicols. 

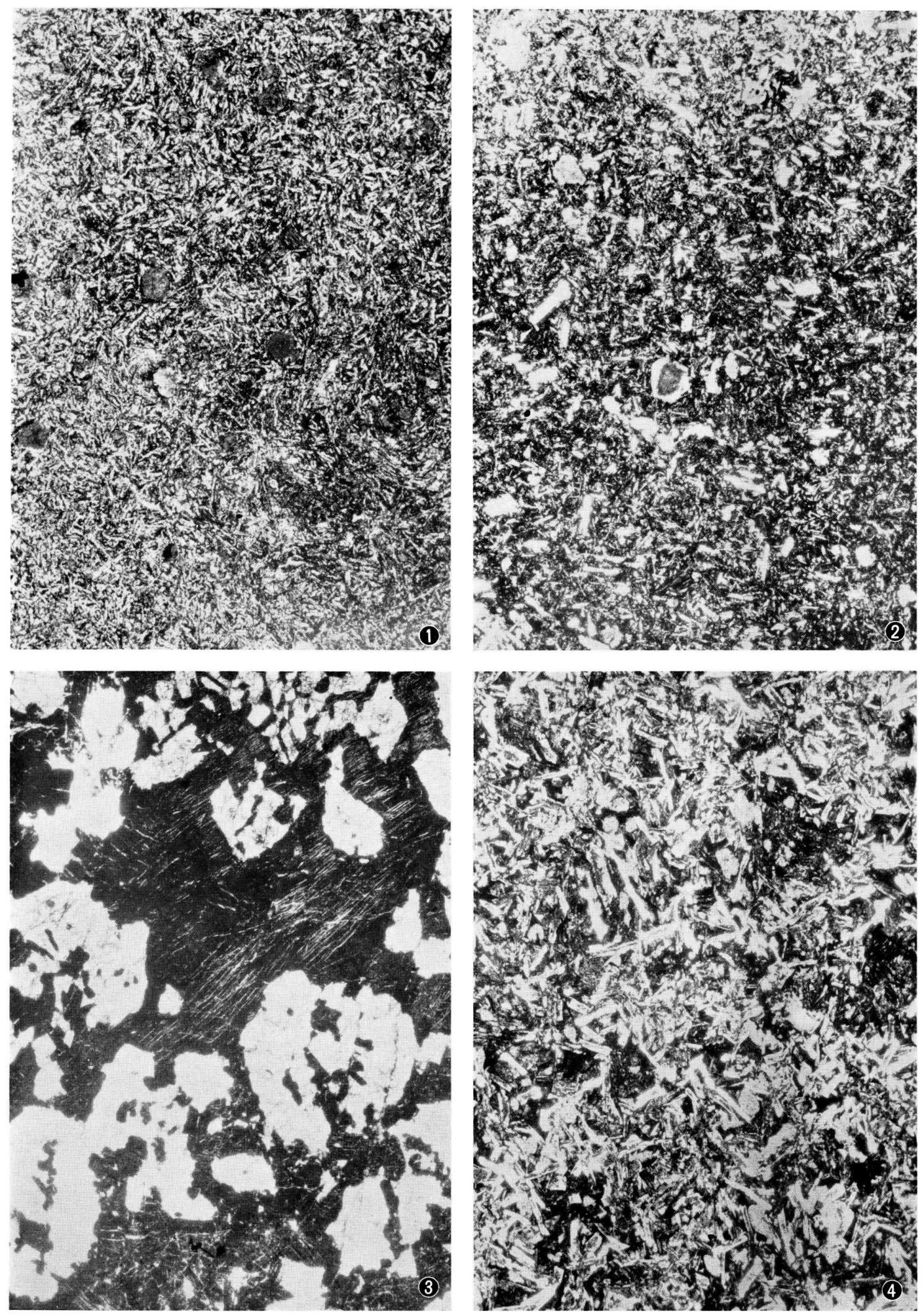

N. Kashima: Stratigraphical studies of the Chichibu belt. 
Plate 59 


\section{Explanation of Plate 59}

(All are of ordinary light; $\times 10$ )

Fig. 1. Pseudomicrite from the Uwagawa Formation (66032901).

Fig. 2. Coarse-grained pseudosparite with some remnants of primary limestone containing skeletal grains. From the Uwagawa Formation (68090308).

Fig. 3. Algal biomicrite with some involute foraminifers and gastropods. From the Itagatani Formation (32).

Fig. 4. Siliceous slate with radiolarian remains. From the Itagatani Formation (11). 

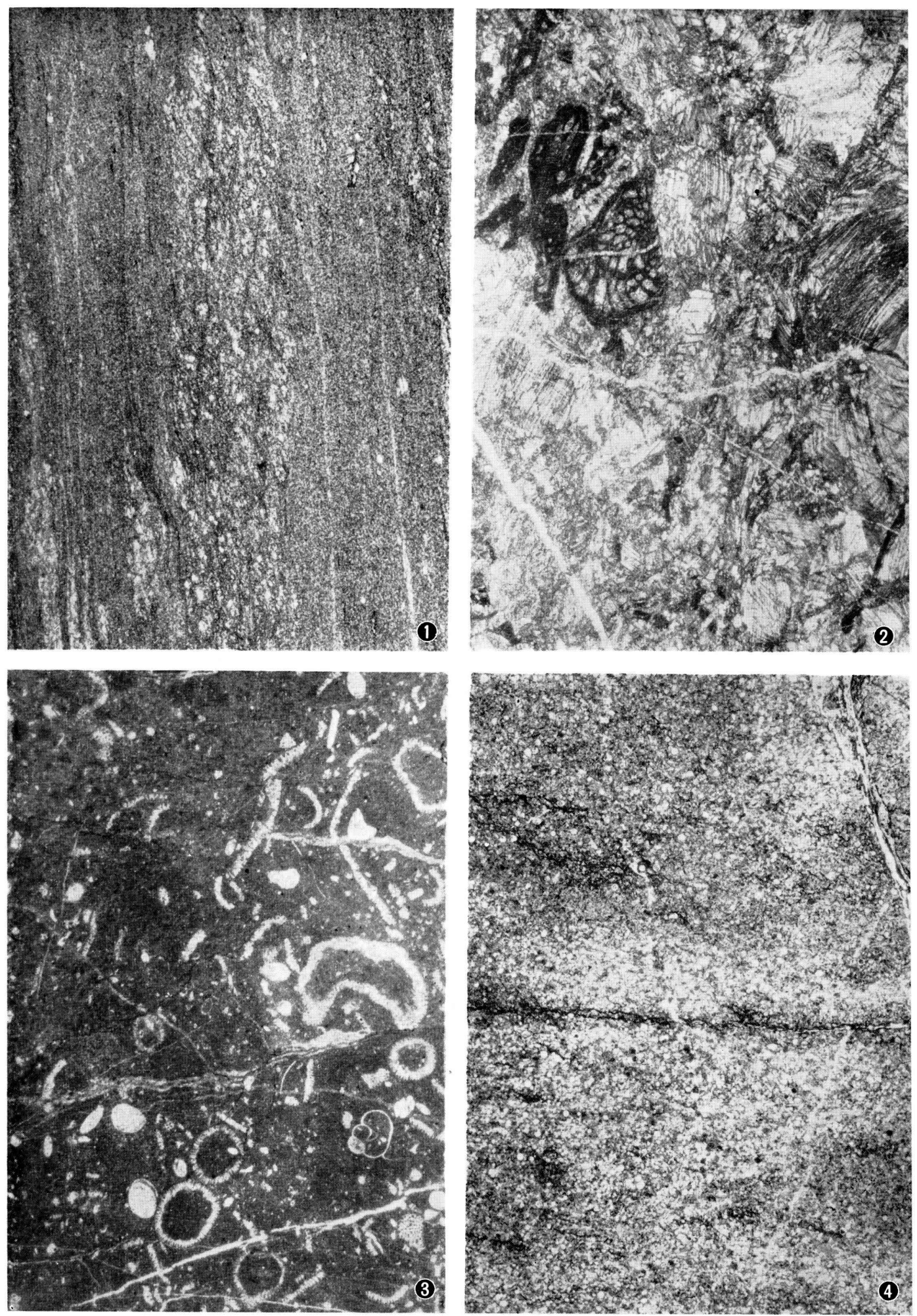

N. KASHIma: Stratigraphical studies of the Chichibu belt. 
Plate 60 


\section{Explanation of Plate 60}

(All are of ordinary light; $\times 10$ )

Fig. 1. Dolomitized pelagic pelecypod biomicrite from the Uonashi Formation (02).

Fig. 2. Pelagic pelecypod biomicrite consisting of a great number of thin-shell (Bositra) debris with a micritic matrix. In part a small amounts of radiolarian remains are contained. From the Uonashi Formation (102012).

Fig. 3. Fusuline-crinoid biopseudosparrudite. Secondarily strongly contorted. The matrix is recrystallized to coarse calcite mosaics. From the Uwagawa Formation (68090302).

Fig. 4. Well sorted algae circumcrusted crinoid fusuline biosparrudite. Bioclasts are those of crinoid ossicles, fusulines, smaller foraminifers, dasycladacean algae and a few bryozoa. From the Oyabu Formation (66031420). 

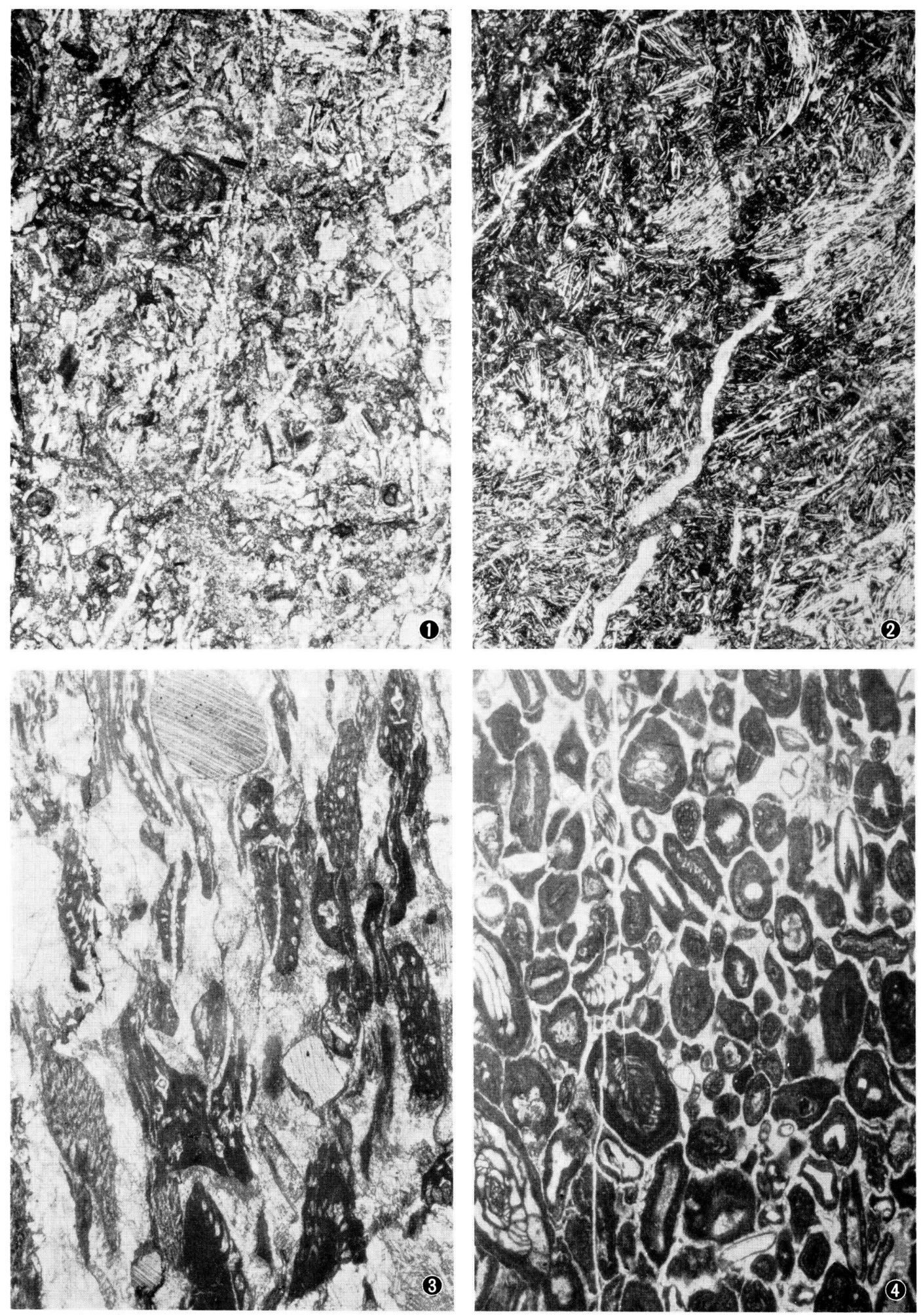

N. Kashima: Stratigraphical studies of the Chichibu belt. 


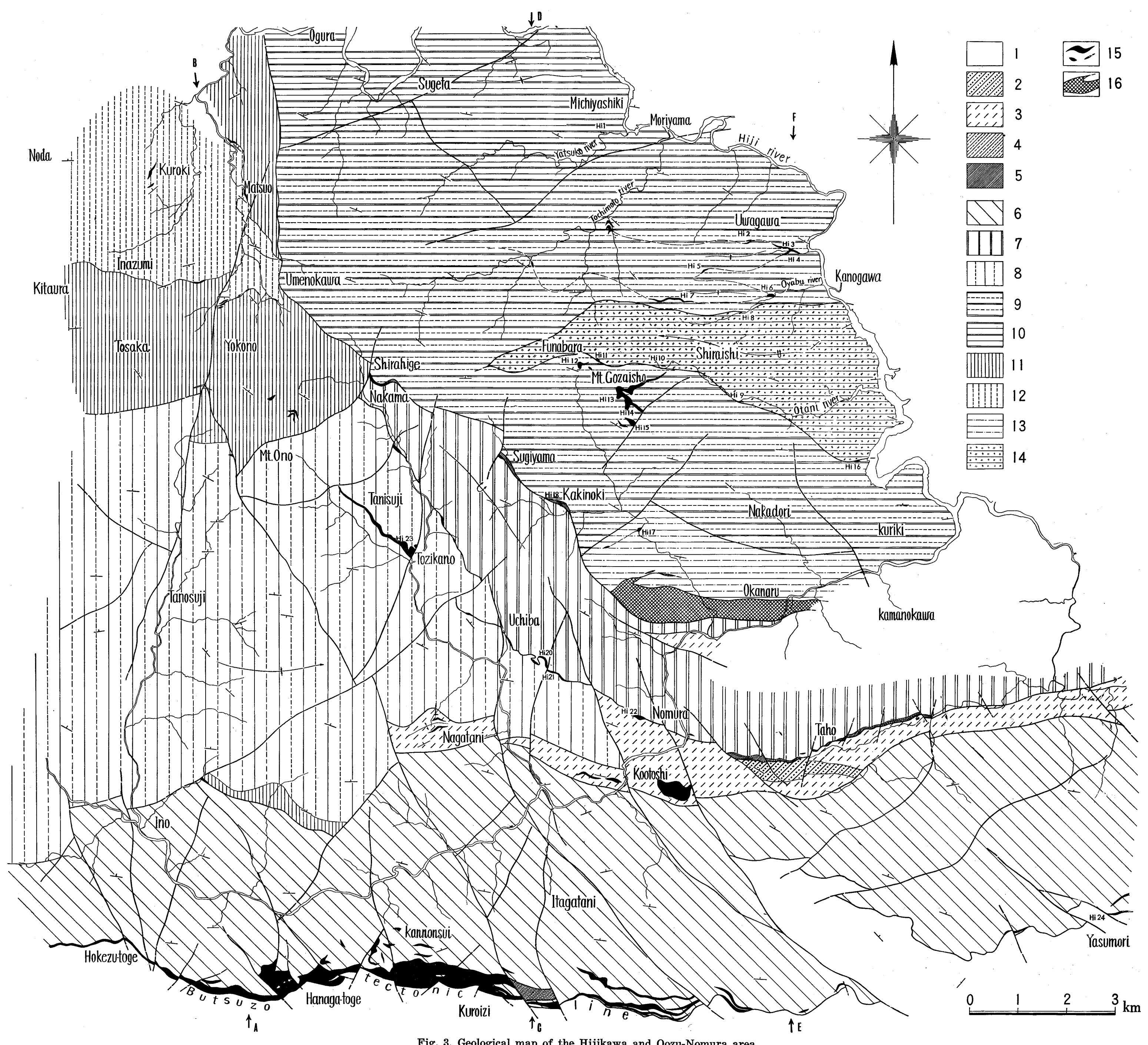

Fig. 3. Geological map of the Hijikawa and Oozu-Nomura area.

1: Shimanto belt, 2: Ryoseki Series, 3: Imaidani Formation, 4: Tanohama Formation (?), 5: Uonashi Formation, 6: Itagatani Formation 7: Nomura Formation, 8: Tanosuji Formation, 9: Uwagawa Formation, 10: Saitaro Formation, 11: Futaiwa Formation, 12: Kume Formation, 13: Kaifuki Formation, 14: Oyabu Formation, 15: limestone, 16: Kurosegawa tectonic zone. 


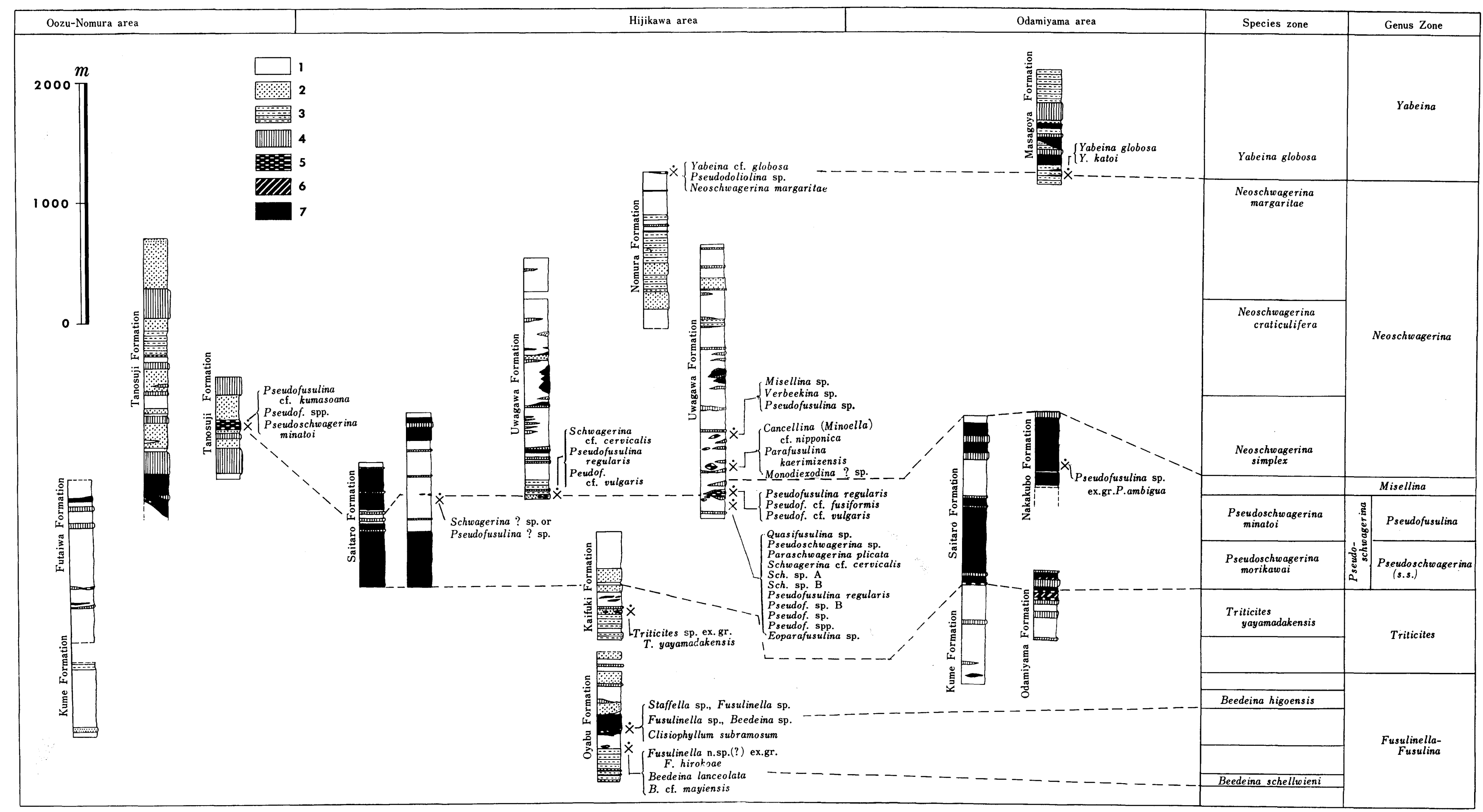

Fig. 5. Stratigraphic columns of the Upper Palaeozoic in western Shikoku.

Lithologic symboles 1: shale, 2: sandstone, 3: sandstone and shale in alternation, 4: chert, 5: limestone, 6: dolomite, 7: greenstones. 